\title{
REFUGIOS ANTIAÉREOS DE LA GUERRA CIVIL EN ALICANTE: INTERVENCIONES ARQUEOLÓGICAS EN LAS PLAZAS DE SÉNECA Y DR. BALMIS
}

\author{
CIVIL WAR AIR RAID SHELTERS IN ALICANTE: ARCHAEOLOGICAL EXCAVATIONS IN THE SENECA \\ AND DR. BALMIS SQUARES
}

FRANCISCO LOZANO OLIVARES
MARCOS LUMBRERAS VOIGT

A Margarita Borrego Colomer,

compañera y codirectora de la intervención en la Plaza de Séneca

\section{INTRODUCCIÓN}

La reciente ejecución de los proyectos de remodelación de la Plaza de Séneca y de la plaza del Dr. Balmis de Alicante conllevó el hallazgo de los accesos a dos refugios antiaéreos construidos durante la Guerra Civil Española. Ambos se encontraban documentados en los fondos dedicados a la Defensa Pasiva de la ciudad del Archivo Municipal de Alicante, aunque se desconocía su estado de conservación y características, puesto que permanecían cerrados desde hacía décadas. Su descubrimiento motivó la presentación de un proyecto de seguimiento e intervención arqueológica redactado por la Técnico Arqueóloga del Patronato Municipal de la Vivienda, Margarita Borrego.

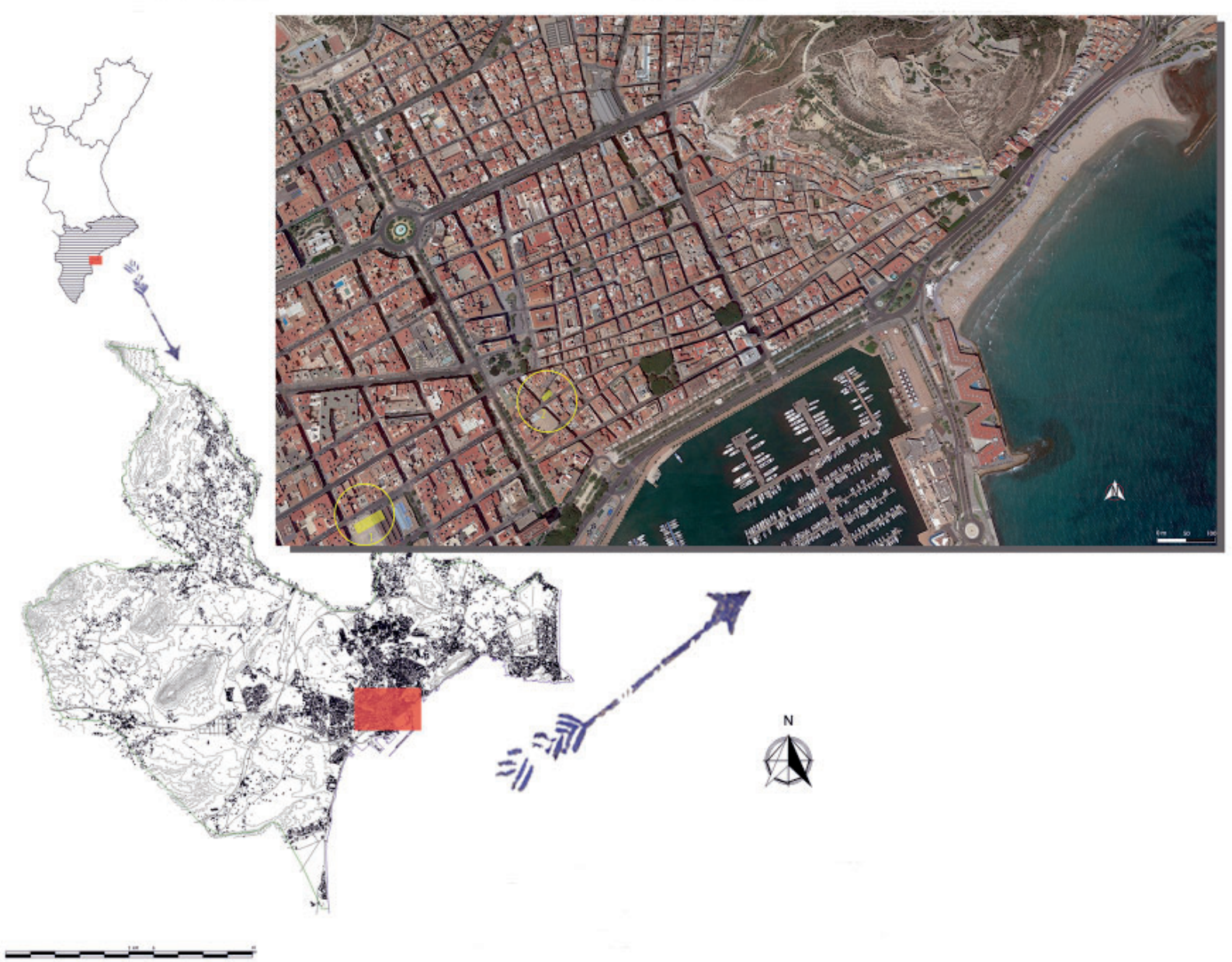

Figura 1: Localización de los yacimientos. 1, Pl. de Séneca. 2, Pl. del Dr. Balmis. 
En lo que respecta a la actuación llevada a cabo en el refugio de la Plaza de Séneca, su comienzo tiene lugar en octubre de 2013, cuando de manera casual y en el transcurso de las obras de adecuación de la plaza, son descubiertos dos pequeños registros con acceso al refugio antiaéreo, que hoy sabemos recae en la esquina de las calles Pintor Aparicio y Pintor Lorenzo Casanova, en el barrio conocido como Séneca-Autobuses. Las entradas quedaron cegadas en la década de los años 40 a raíz de la construcción por un lado de unos bloques de viviendas, y por otro, por la edificación de la Estación Central de Autobuses de Alicante inaugurada en 1947. Los trabajos de adecuación llevaron consigo el derribo de las mencionadas viviendas, además de dos de las marquesinas de la antigua estación, recuperando el lugar su antigua condición de plaza pública.

En cuanto al refugio antiaéreo de la Plaza de Dr. Balmis, se encuentra localizado en la conocida plaza alicantina del mismo nombre, enmarcada por las calles Limones, Cid y Canalejas. Ocupa un área de planta de aspecto cuadrangular de unos $198 \mathrm{~m}^{2}$, y se sitúa en el casco histórico de Alicante, en el extremo oeste del céntrico barrio de San Francisco a escasos $200 \mathrm{~m}$ al norte del área portuaria. La altura a la que se sitúa el yacimiento es de 5,36 $\mathrm{m}$ a nivel del mar. La intervención fue motivada también por la ejecución del proyecto de remodelación de la plaza, que planteaba la demolición de las estructuras existentes. Durante esta fase de demolición de las aceras, remoción y movimientos de tierra previstos, fue exhumado uno de los accesos del refugio, concretamente el situado al noroeste, orientado hacia la calle Canalejas (Fig. 1).

\section{ANTECEDENTES HISTÓRICOS}

Durante la Guerra Civil española se diseñó y elaboró un tipo de guerra aérea desconocido hasta el momento, el bombardeo estratégico aéreo de zona sobre poblaciones situadas alejadas del frente. El conflicto español llegó a convertirse en un laboratorio en el que se ensayaron nuevas armas, tácticas y estrategias, que se emplearían y desarrollarían posteriormente en la II Guerra Mundial. Giulio Douhet sentó las bases de esta doctrina militar que establece como principio básico el bombardeo masivo de poblaciones civiles, plasmada en su libro «Il dominio dell'aria», publicado en 1921 (Cardona Escanero, 2009, 9 ss.).

Desde el mismo instante en que se conocieron los resultados de las elecciones democráticas de febrero de 1936, un grupo de generales dirigido por el general Mola conspiró para dar un golpe de estado. El 17 de julio de 1936 se llevará a cabo la rebelión militar contra el gobierno republicano de izquierdas. El fracaso inicial de este golpe de estado, desembocó en una cruenta guerra civil que se prolongará durante casi tres años y que concluyó con la derrota del Ejército Popular de la Republica Española el 1 de abril de 1939, dando paso a una dictadura que finalizó con la muerte del dictador Francisco Franco en 1975.

\subsection{Los BOMbardeos en AlicANTE}

En Alicante no triunfó la sublevación, quedando en una situación de retaguardia y lejos del frente. $\mathrm{Su}$ puerto, el mejor comunicado con Madrid, será utilizado para descargar material de guerra con destino, tanto a factorías de montaje, como al frente.

El primer bombardeo aéreo de Alicante tuvo lugar el 5 de noviembre, cuando un hidroavión Heinkel He59 de la AS/88, procedente de El Atalayón en Melilla, lanzó sus bombas durante la noche (Vicedo Jover, 1994, 106). La ciudad volverá a ser atacada en la noche del 28 al 29 de noviembre. En esta ocasión, la ciudad fue objetivo de un intenso bombardeo llevado a cabo por 16 aviones Junkers Ju-52/3m de las escuadrillas 2.K/88 y 3.K/88 de la Legión Cóndor que, bombardean la ciudad con un una carga combinada de bombas (alrededor de 19 toneladas) de fragmentación, perforantes e incendiarias (Puchol Franco, 2013, 63-75). Este raid, que partió también de Melilla, será conocido como el bombardeo de las 8 horas y sería rememorado en la nochevieja de 1936-1937, por los operadores de dichas unidades, en los versos de un poema (SchülerSpringorum, 2014, 242), del que reproducimos un breve fragmento:

Susurra en las colas de caballo, el mar resplandece sospechoso, desde Melilla hacia España brama el escuadrón del Zorro.

\section{Llevan consigo hecatombes, un cargamento bien puro, han llevado a Alicante un buen puñado de bombas (...)}

Estos ataques contaron con la ayuda de información obtenida por medio del espionaje de buques alemanes (Schüler-Springorum, 2014, 268), y quizás estuvieron estrechamente vinculados a la llegada al puerto de Alicante de navíos con diverso material de guerra de muy variada procedencia y destinado al frente.

Alicante no volvería a ser bombardeada hasta el día 11 agosto de 1937, siendo hostigada a lo largo de todo el año. Una vez establecida la Aviazione Legionaria Italiana en los aeródromos de Mallorca, bombardea el litoral mediterráneo desde Almería hasta la frontera francesa. Ciudades como Barcelona, Tarragona, Manresa, Granollers, Girona, Castellón, Sagunto, Valencia, Cullera, Gandía, Alcoy, Alicante, Denia, Elche, Torrevieja, Águilas, Mazarrón, Cartagena, Almería, entre otras poblaciones del levante peninsular, padecieron continuos ataques aéreos diurnos y nocturnos hasta la finalización del conflicto (Fig. 2, A). 


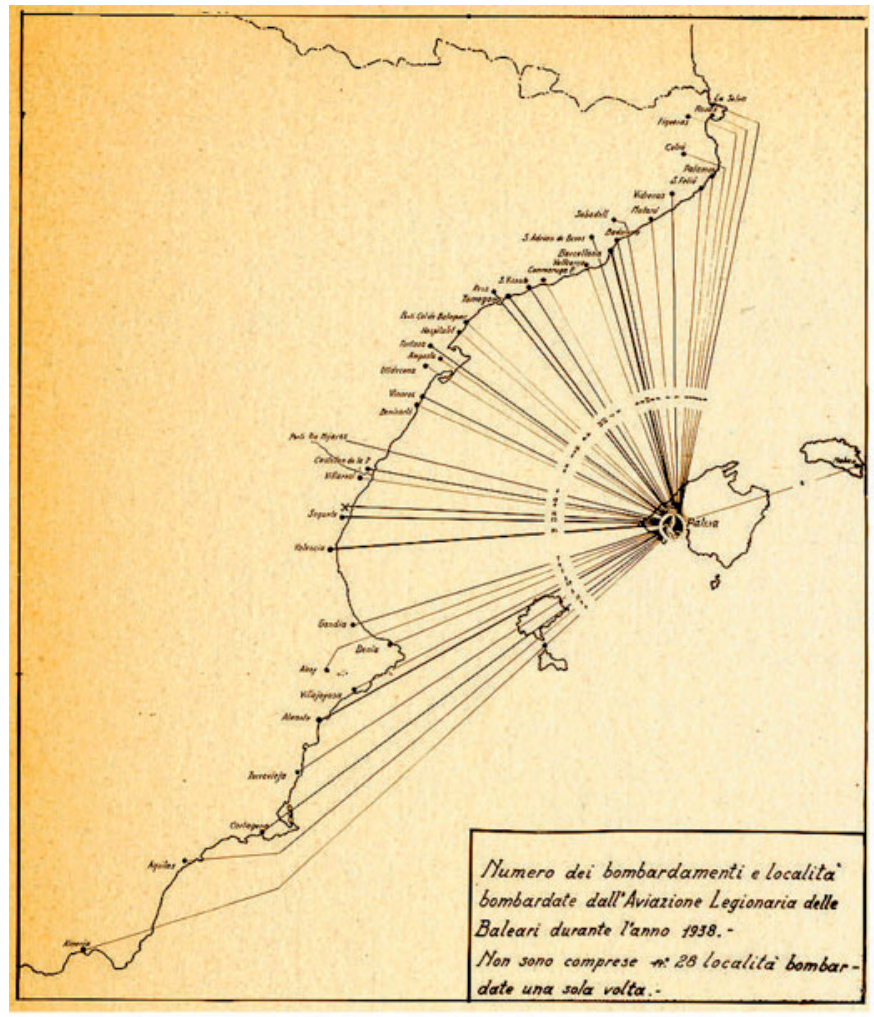

A

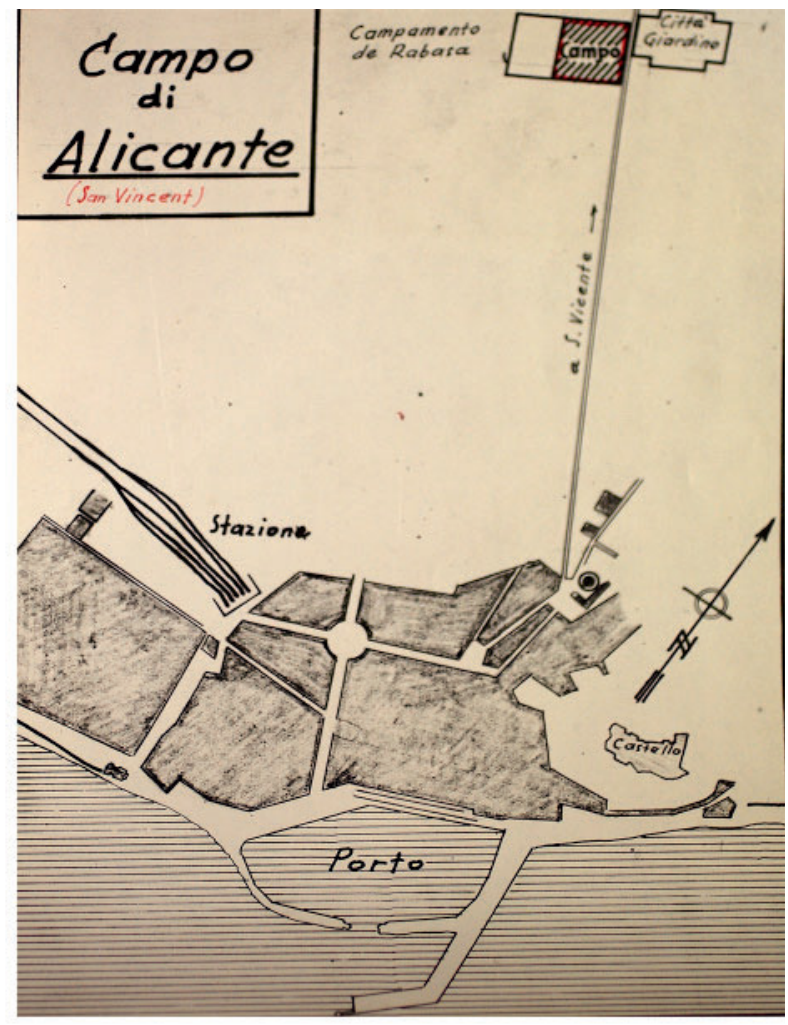

B

Figura 2: A. Mapa italiano en el que se indican las localidades y bombardeos realizados en 1938 (Ufficio Storico Aeronautica Militare Italiana). B. Plano esquemático de Alicante utilizado por los italianos como guía para el bombardeo en 1938 (U.S.A.M.I.).

Alicante y su inmediato entorno sufrió al menos 83 bombardeos aéreos y navales durante toda la guerra (Aracil y Villaroya, 2010, 223), con más de 480 muertos y 740 edificios destruidos, siendo más intensos a partir de 1938, resultando especialmente cruento el del día 25 de mayo de 1938, en el que 7 aviones Savoia S-79 de la $10^{\mathrm{a}}$ y la $19^{\mathrm{a}}$ escuadrillas del XVIII Grupo de Bombardeo Veloz del $8^{\circ}$ Stormo, lanzaron unas 6 toneladas de bombas de 100, 50, 20 y $15 \mathrm{~kg}$. El ataque causó estragos en el mercado de abastos, falleciendo en torno a 300 civiles.

El cuerpo diplomático, al igual que ocurriría con los duros bombardeos de Barcelona en marzo y de Granollers el 31 de mayo, haría públicos comunicados de protesta y condena de tales hechos. Es en 1938, cuando los bombardeos se llevaron a cabo con más crudeza, a pesar de que el tráfico portuario y la llegada de material militar se había reducido en relación a años anteriores. Incluso en 1939 las incursiones aéreas seguían llevándose a cabo con intensidad, sufriendo el último ataque el día 25 de marzo de 1939. Cinco días después la ciudad será ocupada por las tropas italianas del C.T.V.

\subsection{OBJETIVOS DE LOS BOMBARDEOS}

Los protagonistas de la mayor parte de las agresiones serían los Savoia Machetti SM-81 y los SM-79.
Si bien, en principio, los principales objetivos de los bombardeos serán militares y económicos, también es cierto que se intentó aterrorizar y desmoralizar a la población. Se pretendía evitar el despliegue de armamento, municiones, tropas y alimentos destinados al gobierno republicano, y provocar el progresivo estrangulamiento de la economía republicana hasta colapsarla, con el hostigamiento de los centros de producción y de distribución.

Se consideró como objetivo la población civil en muchas de las misiones llevadas a cabo por la Legión Cóndor y la Aviación Legionaria sobre las ciudades del litoral mediterráneo republicano. La desclasificación de gran parte de la documentación llevada a cabo por diversas naciones, ha aportado nuevos y esclarecedores datos, como demuestran los resultados de las recientes investigaciones desarrolladas por numerosos especialistas. Recientemente se ha publicado parte de esta documentación, así en el radiotelegrama $\mathrm{n}^{\circ}$ 45.107 del 11 de febrero de 1937 se ordena al crucero italiano Eugenio di Savoia que bombardee el centro de la ciudad de Barcelona (Contel i Ruiz, 2008, 5658). Un centro de la ciudad que no tenía ningún interés militar. De igual forma, en el telegrama $\mathrm{n}^{\circ} 3088$ (Ministeri Affari Esteri, Sp. Fdg.B.11) ${ }^{1}$ enviado por Mus-

1. «La Aviación Balear será reforzada y tendrá la tarea de aterrorizar la retaguardia roja y en especial los centros urbanos». 
solini al General Berti el 14 de diciembre de 1937, se le ordena que: «L'Aviazione Baleari sarà rinforzata e avrà compito di terrorizzare la retrovie rosse e specie $i$ centri urbani $\gg^{2}$ (Domenech y Zenobi, 2009, 31). En Castellón, en la comarca de L'Alt Maestrat, en mayo de 1938, pequeños núcleos rurales alejados del frente, sin concentraciones de tropas ni presencia de instalaciones militares, serán desafortunados testigos de los ensayos de bombardeo en picado con bombas de 500 $\mathrm{kg}$ de la Legión Cóndor, llevados a cabo por aviones Junkers Ju-87 (Vives, 2013, 36 s.).

\section{LA DEFENSA DE LA CIUDAD}

\subsection{LA DEFENSA ACTIVA}

Las consecuencias inmediatas, sino urgentes de los primeros bombardeos, estaban encauzadas en la necesidad de proteger a la población, y reducir en la medida de lo posible, la pérdida de vidas. En España existía una temprana preocupación por el peligro que suponían los bombardeos aéreos. En 1911 se compran las primeras piezas de artillería antiaérea; posteriormente, se importará de Gran Bretaña diverso material en gran cantidad, y ya en 1931 es creado el primer grupo de artillería antiaérea. Durante la II República éste desaparecería, y en su lugar serían creados dos grupos de Defensa Contra Aeronaves. Además, se contaba con regimientos de defensa en las bases navales. El 30 de abril, en consejo de ministros en Valencia, se aprueba por decreto unificar dentro del Arma de Aviación a la Jefatura de la Defensa Especial Contra Aeronaves (DECA), sustituyendo a la antigua DCA. A partir de este momento dependerá del Ministerio de Marina y del Aire.

Al inicio de la guerra, la aviación con la que se contaba era obsoleta y reducida en número. Alemania e Italia iniciaron sus envíos en fechas muy tempranas, tanto materiales como humanos, mientras que la Unión Soviética lo haría a finales de 1936. Alicante contaba con el aeródromo de La Rabassa, dotado con escasas unidades aéreas de cazas anticuados, ya que la mayoría eran destinados al frente. Posteriormente se emplazó una escuadrilla de Polikarpov I-15 en el aeródromo para la defensa del puerto, las instalaciones de la SAF-15 y de la propia base. Esta es reforzada también en determinados momentos con aviones «chatos» y «moscas» dependiendo de las necesidades y disponibilidad de material. No en vano, el aeródromo sería bombardeado en 5 ocasiones por la Aviación Legionaria desde las Baleares a partir de 1938 (Ruiz Núñez, 2012, 25, s.) (Fig. 2, B).

Alicante fue dotada con defensas antiaéreas antes de los primeros bombardeos. Estas fueron mejoradas posteriormente. Así se creó el denominado Grupo Fijo de Alicante que, en diciembre de 1938, estaba formado por las baterías $n^{\circ} 32$ trasladada desde Los Alcazares, la $\mathrm{n}^{0} 110$ y la $\mathrm{n}^{\mathrm{o}} 712$, así como destacamentos de cañones Oerlikon, ubicados en la sierra de San Julián. El número, emplazamiento y modelos de las piezas empleadas variarían a lo largo del conflicto, dependiendo de las necesidades y disponibilidades de material. De este último modelo llegaron numerosas piezas al puerto de Alicante con destino al frente. Además de la artillería antiaérea y los sistemas de dirección de tiro correspondientes, existían 4 puestos de observación complementados con un fonolocalizador situado en el Cabo de la Huerta y 8 proyectores fijos y móviles.

\subsection{LA DEFENSA PASIVA: LOS REFUGIOS}

En cuanto a la defensa pasiva, el 8 de agosto de 1935 el Ministerio de la Guerra decreta la creación del Comité Nacional para la Defensa Pasiva de la población civil frente a los ataques aéreos y químicos. El objetivo fundamental de dicho comité fue el de tomar las medidas necesarias que requerían las poblaciones en el caso que se produjera el estallido de un conflicto armado. De esta forma, en todas las provincias se debían organizar comisiones provinciales y locales para este fin. Los Comités Locales se constituirían en aquellas localidades de más de 8000 habitantes, y estarían presididos por el Alcalde en lugar del Gobernador Civil. Esta estructura será la base de todas las Juntas de Defensa Pasiva que se crearon a lo largo de toda la contienda.

En septiembre de 1936 es creado un Servicio de Defensa Pasiva Antiaérea por el Gobierno de la Generalitat de Cataluña, siendo pionero y sentando las bases normativas de otras juntas de defensa pasiva, como la creada en Alicante el 1 de julio de 1937 (AMA Arm. 19. Leg. 31/3), teniendo lugar su primera sesión oficial el 10 de julio de 1937 (AMA Arm. 19. Leg. 30/5). Esta Junta Local, al igual que el resto de las juntas, estaría bajo la dirección de la DECA, y la componía un equipo de distintos profesionales competentes en la materia. Así mismo, se ocupaba de la financiación de los gastos generados por la construcción de los refugios antiaéreos, ya fuera por aportaciones públicas, impuestos y donaciones.

Sin duda, el principal cometido de esta Junta Local, será la construcción con la mayor rapidez de un número suficiente de refugios, capaces de albergar la máxima cantidad posible de población. En la relación de refugios existentes en Alicante del 9 de marzo de 1937, donde se diferencian según su tipología, ya sea en sótano, losa de hormigón y galería, encontramos 21 refugios construidos, 2 en proyecto y 16 en construcción (AMA. Arm. 19. Leg. 30/2). Un año después, en la memoria de julio de 1938 de la Junta Local de Defensa Pasiva de nuevo se enumeran someramente los tipos de refugios construidos en Alicante. Estos responden a la voluntad de adaptar las construcciones a las necesidades de defensa, y a las características topográficas y geológicas del terreno en el que se 
emplazarán los refugios. Todo ello con el objeto de conseguir una relación de coste por persona lo más reducida posible. En este documento se indica que en fecha de 1 de julio de 1937 existían en la ciudad 18 refugios edificados con capacidad para proteger a 8.070 personas y otros 15 refugios estaban en construcción para 9.900 personas. En julio de 1938 ya existían 55 refugios, aumentando la protección a 38.140 personas. El plan general de refugios tenía proyectado, en ese momento la construcción de 37 refugios más. De esta forma se alcanzaría una capacidad total estimada de unas 108.590 personas (AMA Arm. 19, Leg. 31/3). Al finalizar la contienda, se puede hablar de la existencia en torno a los 90 refugios construidos y/o en fase de construcción en el término municipal de Alicante (Fig. 33).

\subsubsection{Tipología de los refugios}

En la Memoria elaborada por el Arquitecto Municipal y el Ingeniero de caminos nombrados para el estudio de las defensas antiaéreas de Alicante del 9 de marzo, y que dirigen al Excmo. Señor Ministro de Obras Públicas (AMA Arm. 19, Leg. 30/2), se establecen tres tipos o modelos fundamentales de refugios dependiendo de las características de la zona en la que se emplazarán. Pensamos que se trata de modelos ideales que sufrirían adaptaciones dependiendo de las circunstancias como la escasez de materiales constructivos, la topografía, la disponibilidad de mano de obra, materiales y del presupuesto. Según la citada memoria estos se pueden enumerar en:

Tipo 1: Se trata de refugios con solera y muros de mampostería hormigonada y como protección superior presentan una losa de 1,25 $\mathrm{m}$ de altura de hormigón armado con cuatro capas de hierros. Sobre esta losa de hormigón existe una capa de arena de 0,40 m, y sobre ella otra rompedora formada por adoquinado de piedra dura o mampostería con mortero formando un blindaje de tierra dura en su superficie. A este tipo de edificación se correspondería el refugio de la plaza de Séneca entre otros.

Tipo 2: Este se puede emplear cuando el terreno sea de tierra dura o roca, careciendo de muros, aunque en el caso de tierra debe revestirse la galería de una hilada de ladrillos. Es el más eficaz de los estudiados y se hace en los sitios de máxima exposición. La defensa superior es idéntica al modelo 1, pero la losa está casi en su totalidad sobre el terreno para evitar una excavación costosa.

Tipo 3: Se realizan en un macizo de hormigón en masa en el que se practican o moldean dos galerías en forma de sector circular, mayor que un semicírculo con diámetro de tres metros, y sobre el macizo, una serie de capas de mampostería alternada con capas de arena, cubiertas con un tejado a dos aguas. Este tipo es apropiado para solares, siendo practicado en terrenos difíciles de excavar por su proximidad al mar. Pensamos que a este tipo, con alguna diferencia, correspondería el refugio de plaza Dr. Balmis, al igual que el que se encontraba en la calle de Alfonso el Sabio, la Escuela Modelo y el del depósito de máquinas de la estación de ferrocarril de M.Z.A., todos ellos dotados de anillos de seguridad. (Fig. 3, A, C, D).

Hemos de resaltar que, entre estos modelos, se advierte la ausencia de los construidos en laderas y elevaciones del terreno, excavando túneles y aprovechando la protección natural ofrecida por la topografía o de estructuras ya existentes, adaptándolas, ampliándolas y reforzándolas. En este conjunto se encontraría el de la Plaza de La Montañeta, laderas de los castillos de Sta. Bárbara, S. Fernando y Pozos de Garrigós. Otros refugios no enumerados y que vemos conveniente mencionar son los localizados en sótanos de viviendas particulares y en fábricas.

Muchos de los refugios se edificaban bajo calles y plazas. Debido a que se construían a escasa profundidad para abaratar costes y evitar el nivel freático, sobre ellos se edificaban unas estructuras denominadas cumbreras. Estas se elevaban sobre la rasante de la calle bloqueando e impidiendo parcial o totalmente el tránsito por la calle o plaza. Eran estructuras de unos 2 metros de altura, de aspecto troncopiramidal, realizadas en mampostería hormigonada. Se trataba de blindajes externos cuya función era aumentar la resistencia a un impacto directo de bombas y favorecer, en la medida de lo posible, el rebote de las mismas debido a los diferentes grados de inclinación de sus muros.

De gran valor documental para conocer las características de los refugios construidos en la ciudad de Alicante, podemos consultar el borrador de un informe redactado por el Arquitecto Municipal, con fecha de 20 de enero de 1938, donde se propone una serie de recomendaciones para adjuntar a las Ordenanzas Municipales vigentes, que tendrían un carácter de uso obligatorio para las edificaciones de nueva planta (AMA, Arm. 19, Leg. 30/2). En este informe, se incide en la obligatoriedad de construir en aquellos edificios que alberguen gran número de gente como edificios populares o industrias, cifrando su capacidad a razón de 4 personas por $\mathrm{m}^{2}$. También se establece las dimensiones mínimas internas, o las pendientes y números de peldaños que deberán tener las escaleras de accesos. Accesos, que por norma deben de ser al menos 2 , dotándoles a su vez de un trazado para que la onda expansiva de las bombas no entre en el interior. Incluso se especifican los volúmenes del hormigón o las cantidades de arena, cemento y grava para su mezcla. Por otro lado, también se indica el uso de respiraderos o la disposición de equipos de ventilación. Como hemos podido comprobar, esta normativa se cumple casi a rajatabla en la construcción de la 


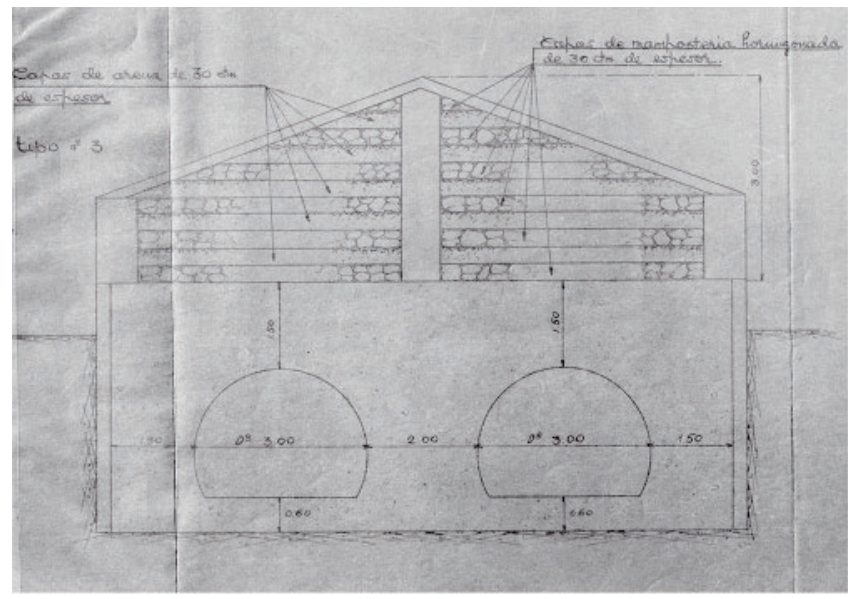

A

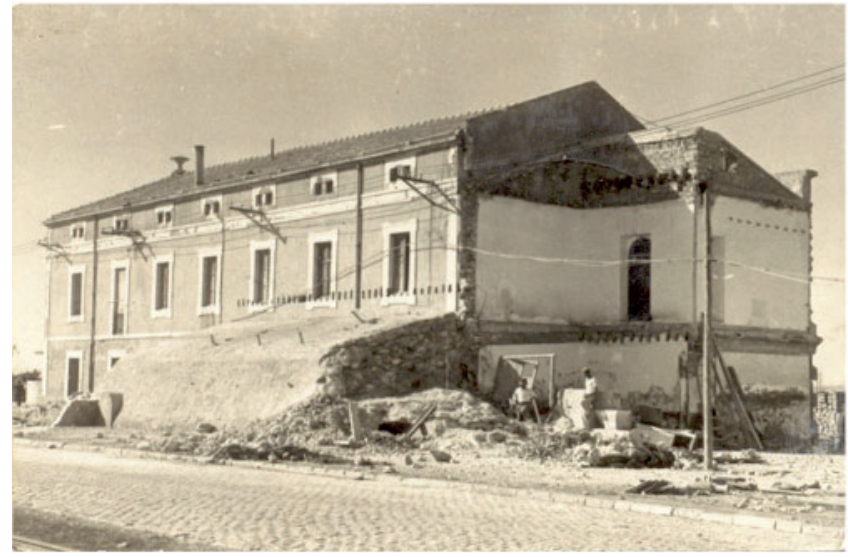

B

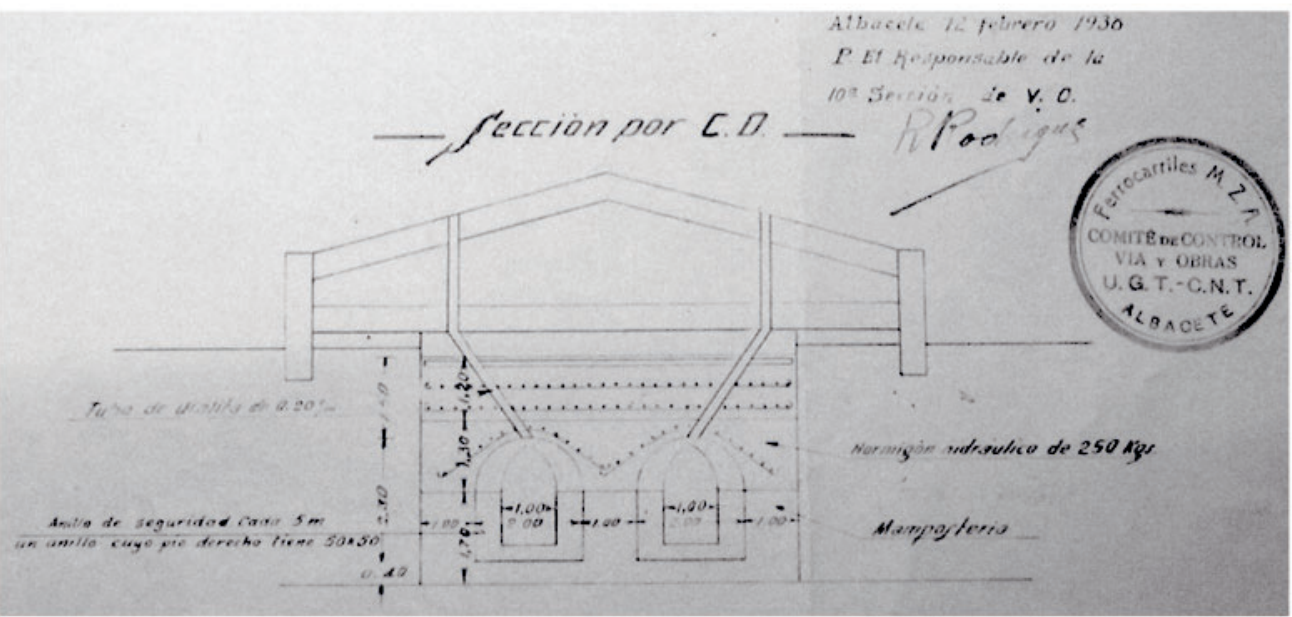

D

Figura 3: A. Sección del refugio tipo 3. A este tipo, con notables diferencias, correspondería el refugio de la plaza Dr. Balmis (AMA, Arm. 19, Leg. 30/2. Plano 800). B. Fachada E de la antigua Comandancia de Marina del puerto. Se ve claramente el blindaje del refugio adosado al edificio gravemente dañado por los bombardeos (AMA Sanchez). C. Sección y planta del Refugio de la calle Alfonso X (AMA, Arm. 19, Leg. 30/67). D. Una de las secciones del refugio situado en el depósito de máquinas de la estación de M.Z.A. (AMA, Arm. 19, Leg. 30/17 bis. Plano 453).

gran mayoría de los refugios públicos de Alicante, y la podemos ver expresada de manera material, en la

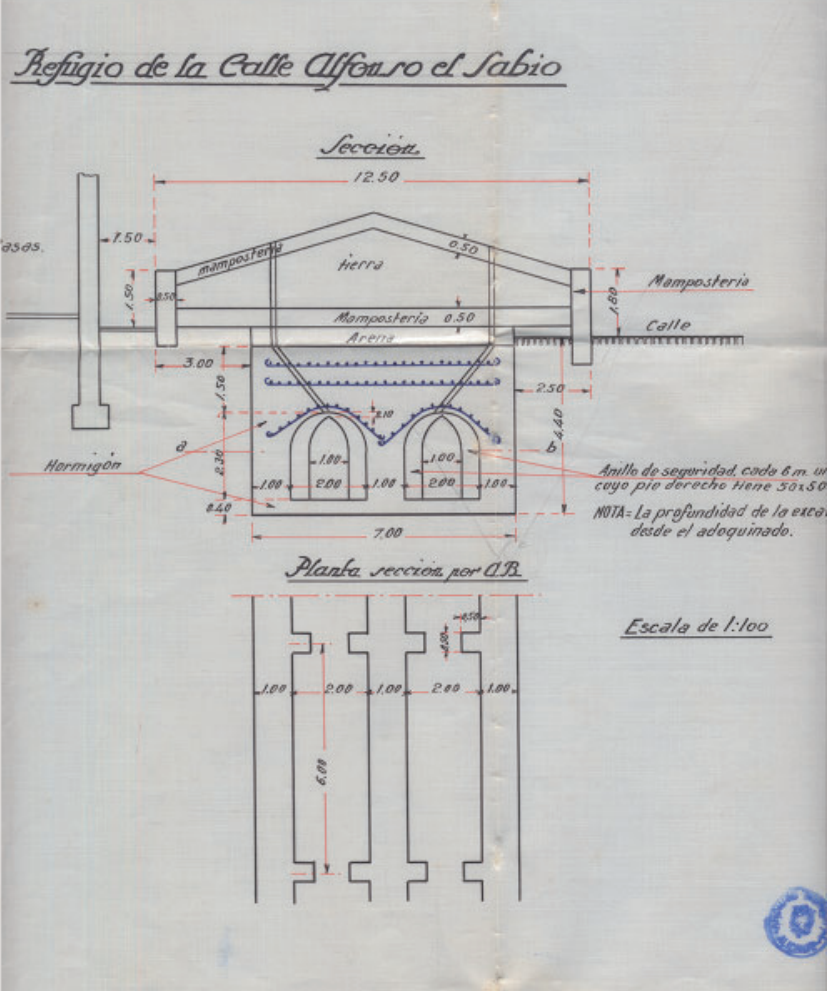

C 


\section{EL REFUGIO DE LA PLAZA SÉNECA}

\subsection{REFERENCIAS DOCUMENTALES}

Remontándonos a los tristes años de la Guerra Civil, las primeras referencias documentales que tenemos sobre su existencia se corresponden a un legajo conservado en el Archivo Municipal de Alicante, y en el que vemos una relación de refugios existentes en la ciudad con fecha de 9 de Marzo de 1937, y firmado por el Arquitecto Municipal (Fig. 4). En este mismo documento ya se hace una mención a los tipos de refugio, colocando al de la Plaza de Séneca entre los llamados de losa de hormigón, además de señalar que se encontraba en construcción en esos momentos (AMA Arm. 19 leg. 30 /31).

Debemos consultar la prensa de aquellos años, para encontrar la siguiente referencia publicada algunos meses después en el periódico Nuestra Bandera, con fecha de edición del 25 de Agosto de 1937 (AMA Nuestra Bandera 25 de agosto 1925). Aquí se menciona en un listado de refugios que como dice el propio periódico «hoy existen en Alicante», por lo que suponemos que ya estaría construido o en construcción. Lo cierto es que de este mismo mes y año, contamos con una factura y nóminas pagadas por la Junta de Defensa Pasiva donde se especifican los jornales cobrados por los operarios $\mathrm{u}$ obreros que participaron en la construcción, a razón de 14 pesetas para el encargado y 10 para los peones por jornada trabajada. Sobre este documento volveremos a hablar acerca de los trabajadores citados en dicha factura (AMA Arm. 19 Leg. 30/17 Bis). Otro documento, es el que señala ya su pleno funcionamiento en Julio de 1938, en la memoria de la Junta de Defensa Pasiva de ese mismo año. Además de asignarle el número 31 en la lista del Plan Parcial de Refugios, se le dota de un aforo más acorde a la realidad hoy documentada de 1200 personas, y no las 2500 que leíamos en las primeras fuentes y cuando el refugio se encontraba todavía en construcción (AMA Leg. 31/3).

Una vez terminada la guerra, once años después, y con una nueva Junta Nacional al frente de los refugios, parece que su trabajo continua al albur de los nuevos tiempos y la nueva amenaza nuclear, realizando labores de mantenimiento o incluso autorizando usos tan dispares como la del cultivo de champiñón en alguno de ellos (AMA Arm. 19 Leg. 30/20). Así, en estos años de postguerra tenemos un documento que recoge la Ponencia Municipal del llamado Plan fusionado de refugios e incendios de 1950 (AMA Arm. 19, Leg. 31), en el que llama la atención que nuestro edificio no se encuentre en la lista de refugios, más si cabe cuando en el año 1953 aparece de nuevo en las listas de una nueva ponencia del Plan de Refugios e Incendios de ese mismo año (AMA Arm. 19 Leg. 30/17). El refugio queda descrito con los accesos tapiados, y se le dota de una capacidad de 1000 personas. Es evidente, como hemos comprobado tras la excavación, que en

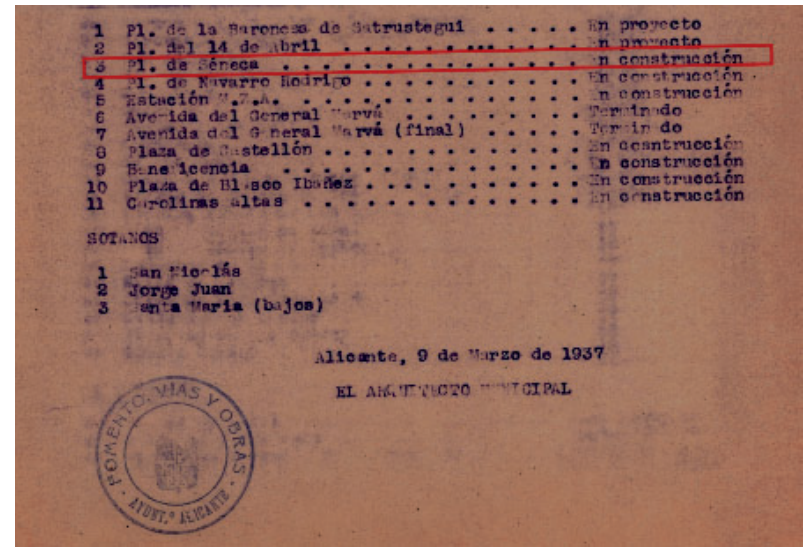

Figura 4: Primera referencia documental. Refugio de la Plaza Séneca del 9-3-1937 (AMA Arm. 19 leg. 30 /31).

esos días los accesos al refugio estarían ya sellados al menos unos 5 años, y que la capacidad que ofrece dicho documento sería más acorde a la realidad.

Contamos también con otras referencias documentales, que si bien no hacen mención directa al edificio, sí a la zona en la que se encuentra construido, y en el contexto bélico de la Guerra Civil. La zona que en aquellos años se encontraba muy ligada al puerto con numerosos talleres y establecimientos fabriles, pronto comenzará a ser castigada por los bombardeos. Bombardeo como el que tuvo lugar el 28 de noviembre de 1936, conocido como el de las 8 horas, y en el que al parecer fallecieron dos personas una de ellas un niño. Por otro lado contamos con los partes sobre los daños, elaborados por la Junta de Defensa Pasiva, documentos de gran valor para conocer las consecuencias de los ataques sobre la ciudad, y que incluso se acompañan de mapas señalando los puntos de impacto (Fig. 5). Un ejemplo es la relación de daños de los bombardeos desde 25 de julio de 1938, (AMA Arm.19 Leg. 31/5) donde se mencionan, en nuestro caso, los daños ocasionados en el Garaje Curt sito en la misma Plaza de Séneca, y en la incursión del 13 de agosto de 1938. Parece que a consecuencia de este ataque, fueron movilizados los bomberos quienes tuvieron que sofocar un incendio en el lugar. Dato recogido tras la guerra, en los informes de servicios del Cuerpo de Bomberos realizados durante el periodo bélico (AMA Arm.19 Leg. 32/16). Tenemos noticias también de un último bombardeo sobre la plaza y el puerto el 7 de diciembre del año 38 sobre las 12:25 y en el que al parecer no hubo víctimas (Ramos Pérez, 1972, 255), queremos pensar que tal vez gracias al refugio, puesto que ya estaría construido por aquel entonces ${ }^{2}$.

También de gran valor histórico y documental son sin duda las fotografías aéreas realizadas por la aviación

2. Este ataque a la plaza no está recogido en los partes de bombardeos de la Junta, pero sí es recogido por Vicente Ramos (1972, tomo I, 145). 


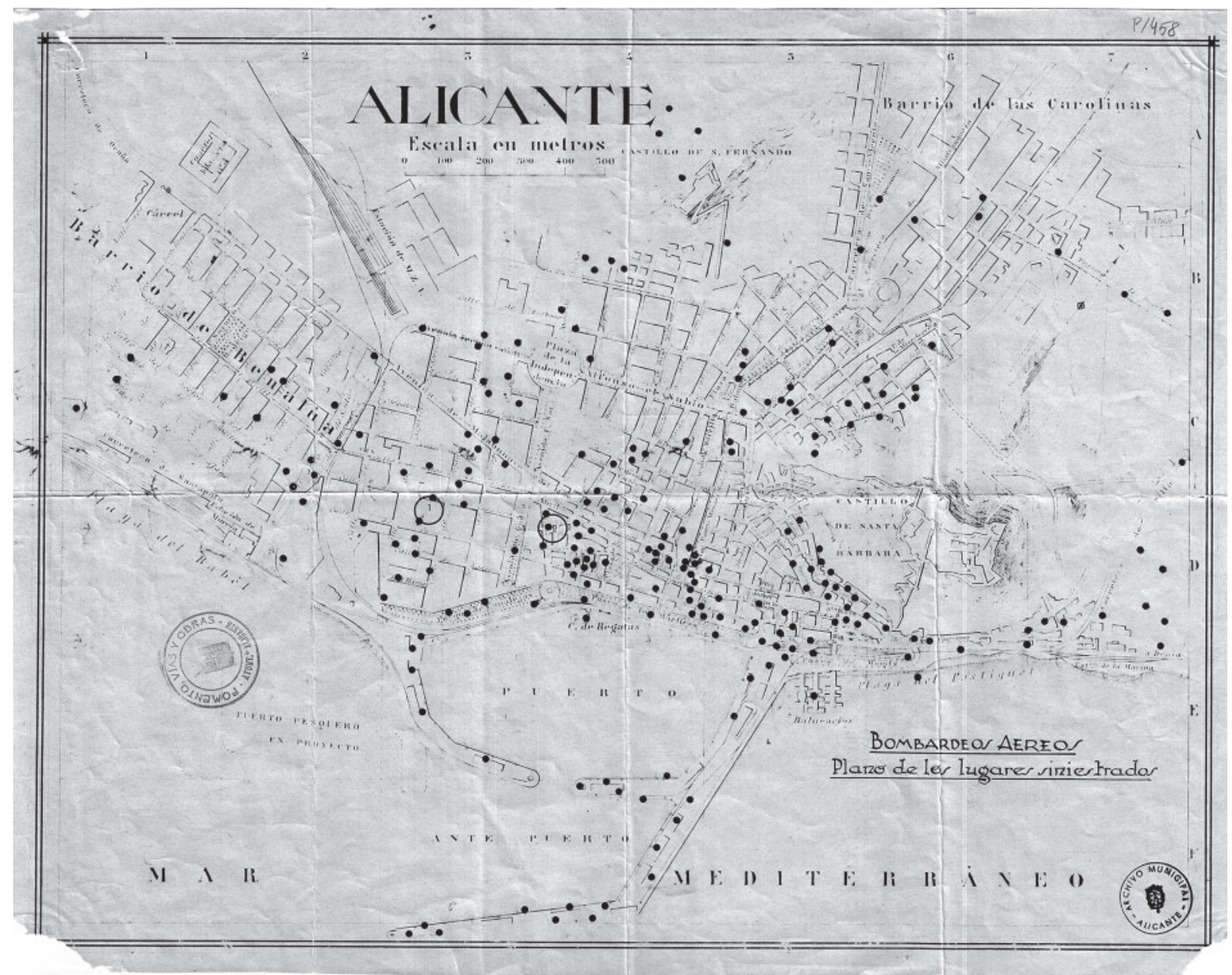

Figura 5: Plano de daños o impactos ocasionados por los bombardeos sobre la ciudad de la Junta de Defensa Pasiva (AMA Arm.19 Leg. 31/5).

italiana que bombardeó la ciudad, y que de manera rigurosa tomó innumerables imágenes de Alicante para determinar objetivos e incluso mientras era bombardeada (Fondi dell'Archivo Storico dell'Aeronautica Militare. Roma). De uno de estos ataques, podemos

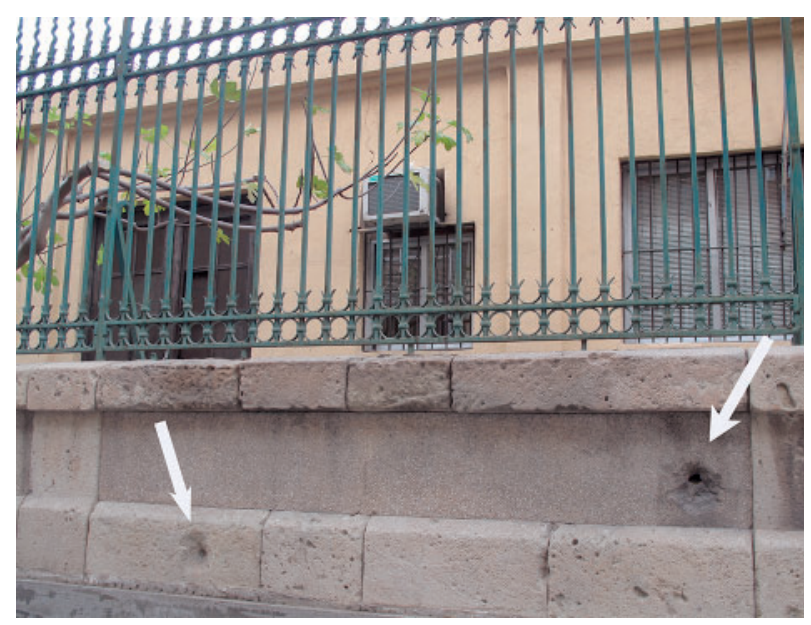

Figura 6: Daños ocasionados en el edificio de la Casa de Maquinas situada en la Plaza de Séneca (M. Lumbreras). ver unas impresionantes fotografías que muestran las consecuencias inmediatas de los impactos de las bombas sobre la plaza, uno de ellos a unos pocos metros del refugio. Hoy en día, al igual que con el bombardeo del Mercado, son visibles los impactos de la metralla en el contiguo edificio de la Casa de Máquinas, en píe en aquellos momentos, y hoy convertido en Centro de Interpretación de los Refugios Antiaéreos de Alicante (Fig. 6). En estas mismas fotos, también podemos ver sin lugar a dudas, la silueta junto a otro edificio ya desaparecido, de una estructura rectangular que hemos identificado como el refugio de la plaza de Séneca. En la imagen ampliada incluso son bien visibles sus dos accesos (Fig. 7, A, B).

\subsection{INTERVENCIÓN Y CARACTERÍSTICAS DEL REFUGIO}

Centrándonos ya en la intervención arqueológica, el edificio y sus características, debemos decir que de manera previa a comenzar a documentar en detalle las características y restos del edificio, se retiró por un lado parte del asfaltado y escombros de la superficie exterior, delimitando así la construcción originaria y 


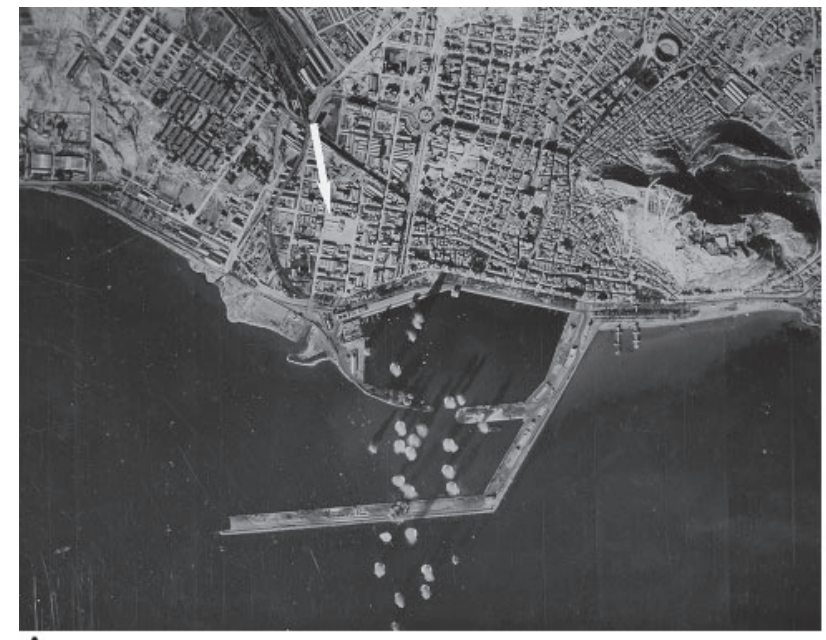

A

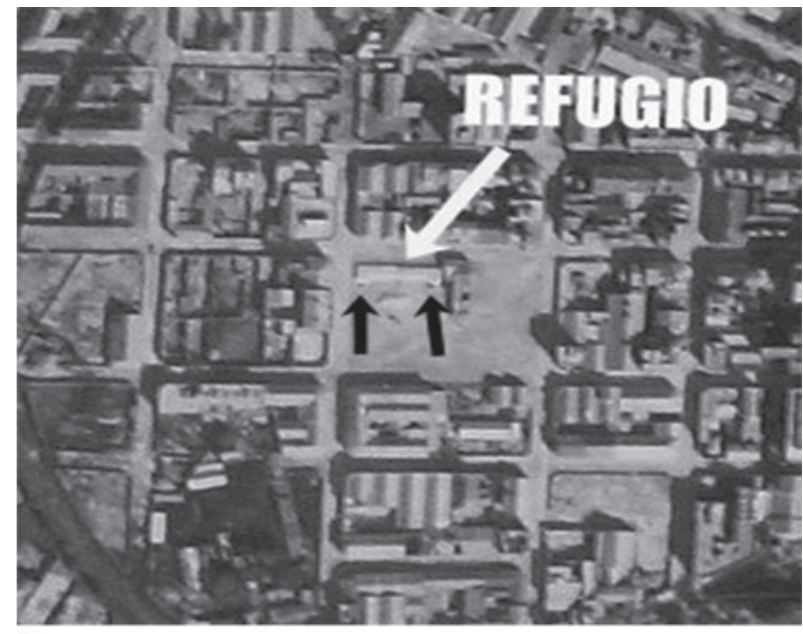

B

Figura 7: A. Fotografía aérea de Alicante de la aviación italiana con Plaza de Séneca y refugio ya construido. B. Fotografía aérea ampliada (Ufficio Storico Aeronautica Militare Italiana).

evitando así daños durante las obras de la plaza. Por otro lado, también se eliminó una potente zapata de hormigón ubicada justo en la escalera del acceso norte, además de ser retirado el relleno de escombros que cegaban la escalera Sur del refugio. En el exterior y ante la impermeabilización de la superficie del refugio, con mejor o peor resultado, tenemos la oportunidad de poder documentar los elementos originarios del refugio. Encima de la losa de hormigón o dintel, vemos los restos de las distintas pavimentaciones que tuvo la antigua estación de autobuses, además de varias correas de cimentación del edificio derribado de 4 plantas, que sostuvo directamente, y sin zanja alguna, la propia estructura del refugio. Así mismo, localizamos los bordes y restos de los 65 respiraderos cerámicos que sobresalen de la losa de hormigón, repartidos entre cubículos y corredores, con un diámetro de 7 centímetros, y longitud máxima de 1'40 m. Otro elemento que hemos considerado como originario, es una capa de tierra sobre el hormigón y por la que también sobresalen en algunas zonas los respiraderos (Fig. 8, A). La capa de tierra estaba destinada a amortiguar los efectos de las bombas evitando que impactaran directamente sobre la losa, tal y como se recomienda en la construcción de numerosos refugios. Claro ejemplo de esta técnica, lo tenemos en el refugio $\mathrm{N}^{\circ} 34$ del Plan de Refugios de la calle General Marvá, refugio muy próximo al de Séneca tipológicamente por planta y estructura (AMA Arm.19 Leg. 30/59. 1937). En su plano sección, se observa como sobre la losa o techo, se dispone de dicha capa y una cubierta o cumbrera de mampostería hormigonada, que muy probablemente tendría también nuestro refugio, perdiéndose en su día, suponemos, a causa de las distintas obras de viviendas y andenes. Tras ser excavada las capas de tierra, dejamos desnuda la losa de hormigón comprobando su morfología, y documentando los huecos aún visibles de los encofrados que en algunos puntos conservan su tabla de madera (la impronta de esas tablas también la tenemos bien definida en el techo del interior). Por otra parte, al dejar al descubierto el exterior, encontramos que el techo o losa del refugio se encuentra elaborada con la técnica llamada de hormigón ciclópeo, mezclando el hormigón con piedras de grande y mediano tamaño (Fig. 8, B). Sobre dicha técnica constructiva, y según consta en el expediente sobre la construcción del refugio de la Escuela Modelo del año 1938, el hormigón ciclópeo podía ir combinado con el armado en una misma edificación, teniendo una proporción de piedra del $50 \%$ por otro tanto de cemento (AMA Arm.19 Leg. 30/6). En nuestro caso, parece que esta proporción se cumple especialmente en la parte central del refugio (Fig. 9) y donde la losa llega a alcanzar un grosor de 1'40 metros. La losa, de cuerpo rectangular, y de la que salen dos brazos en los extremos para sus accesos, tiene una longitud máxima de 51 metros, y una anchura de poco más de 12 metros en los extremos que coinciden con las entradas, teniendo 9 metros en la parte coincidente, con el corredor central y cubículos, lo que supone una superficie total de $492^{\prime} 32 \mathrm{~m}^{2}$ (Fig. 10, A, B). Teniendo en cuenta que el grosor medio de la losa es de 1'20 m, el hormigón empleado llegaría a los $590 \mathrm{~m}^{3}$. Poder delimitar el contorno del refugio en superficie, nos ha permitido también, obtener la anchura de los cuatro muros perimetrales del refugio, que sería, sin contar con los muros de los accesos, de casi 1' 80 metros.

Volviendo al interior y recordemos, quedando ya completamente accesibles las entradas, encontramos en el corredor central del refugio, un frágil tabique de ladrillos que a unos 13 metros de la entrada Norte, y digamos que de manera subterránea dividía las dos distintas parcelas que teníamos en superficie, es decir, la recayente a la estación de autobuses y la de los 


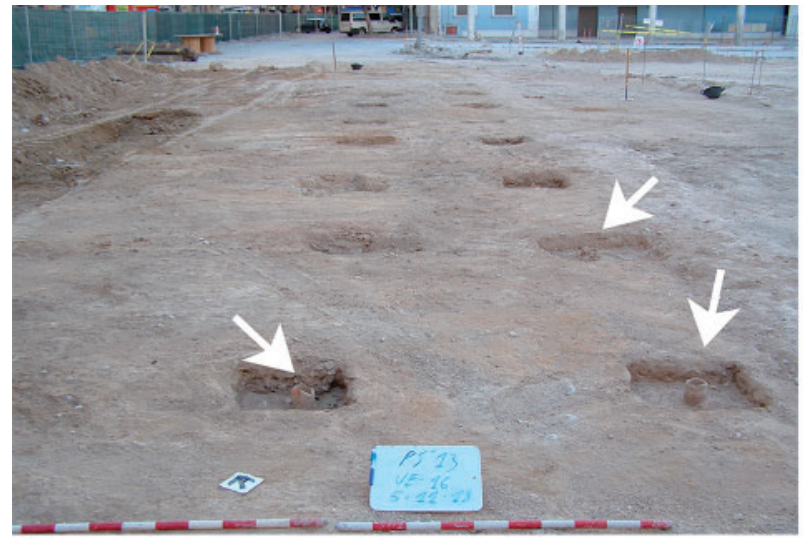

A

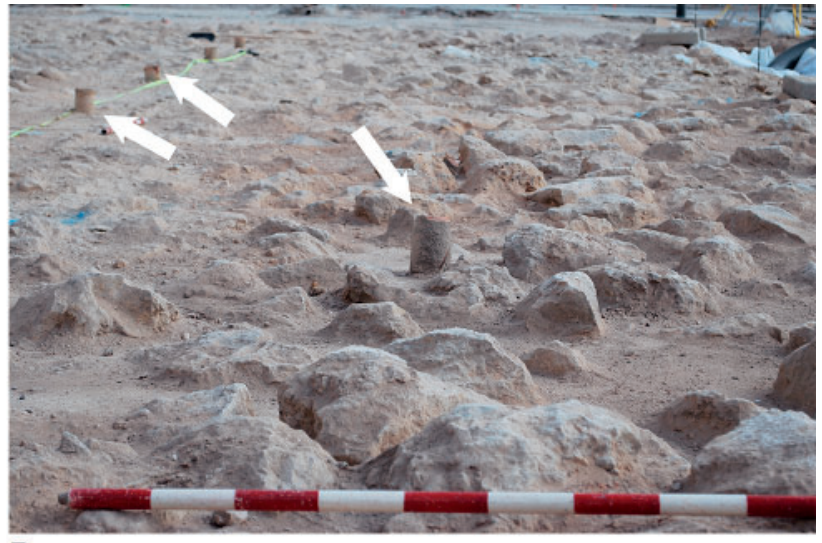

B

Figura 8: A. Exterior del refugio de la Plaza de Séneca con estrato o capa de tierra de amortiguación de impactos junto a respiraderos. B. Exterior del refugio, detalle de la losa de hormigón y respiraderos (M. Lumbreras).

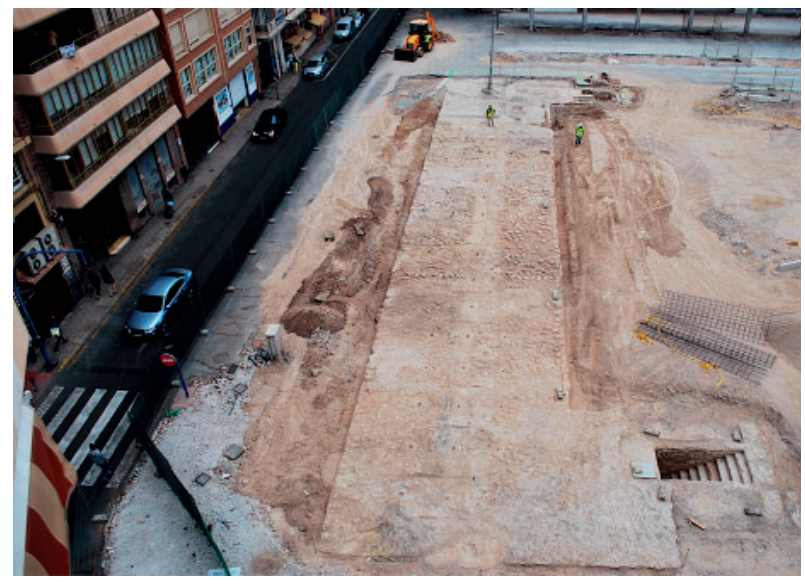

Figura 9: Fotografía aérea del exterior del refugio con planta completa de la losa de hormigón (M. Lumbreras).

bloques derribados de viviendas. Tras poder ventilar el refugio ante la insoportable humedad de años de clausura, se extraen escombros y elementos de obra que lo cegaban, comprobamos su extensión y simetría. En las entradas contamos con dos escaleras de acceso dispuestas en el mismo lado y de idénticas características (Fig. 10, B; Fig. 11, A), con 16 peldaños a lo largo de 4'90 metros, y en cuyos muros de mampuesto irregular todavía vemos los restos del anclaje de los pasamanos. En las mismas escaleras es bien visible la dimensión o anchura de la losa de hormigón que sirve de techo y protección. Una vez dentro, nos encontramos de frente con un ancho muro de 1'20 metros de anchura, que obliga a circular en zigzag hacia el interior. La función de este muro, no es otra que la de servir de protección contra las deflagraciones de los impactos que pudieran producirse en el exterior (Fig. 10, B, D). Este tipo de muros lo tenemos presente en numerosos refugios de la ciudad, especialmente los construidos con losa de hormigón. Un ejemplo son los que tenemos como número 75 o refugio de Plus Ultra y el número 34 o refugio de La Beneficencia (AMA Legs. 30/60 y 30/67). Al entrar encontramos también los primeros rótulos que indican la dirección a seguir y los primeros grafitis, de los que hablaremos más adelante. Como decimos, una vez en el interior, tenemos un gran corredor central de 43 metros de largo y poco más de 1 metro y medio de ancho (Fig.11, B). A este gran pasillo se abren 38 cubículos o celdas de igual tamaño y forma, es decir de casi $3 \mathrm{~m}^{2}$ (Fig. 12, A), salvo los primeros que encontramos en las entradas algo más alargados y de $4^{\prime} 50 \mathrm{~m}^{2}$. En uno de estos, el cubículo primero de la entrada norte, tenemos en los lados de su umbral los restos en yeso de lo que fue una un portón además de las improntas de un estante ya desaparecido. Su situación, rótulo y restos, nos indican que nos encontramos ante un espacio con toda seguridad dedicado a enfermería. Las recomendaciones dadas por las juntas de defensa pasiva sobre construcción de refugios, indicaban la disposición de este tipo de instalaciones siempre en las entradas a los mismos. En el interior vemos también, como los cubículos a lo largo del pasillo, se encuentran separados unos de otros por muros que a su vez cumplen la función de pilares o estribos, puesto que sostienen la fuerte losa de hormigón dispuesta por encima de ellos (Fig. 10, C). Los muros de $0^{\prime} 80$ metros de anchura y una altura que oscila, al igual que la altura del refugio, entre los 2'20 y 2'30 metros, están realizados con técnica mixta, combinando sillares claramente reutilizados de otras obras en su parte baja, y mampuesto irregular en la parte más alta; además se encuentran fijados con fuerte revoco de mortero de cal y encalados. A pesar de su robustez, o por esta razón, la cimentación o zapata de los mismos no bajaba más de 20 centímetros de la superficie, superficie o pavimento a su vez realizado con tierra apisonada sobre un nivel de gravillas. Sobre las paredes de los muros, destacan los rastros del cableado desaparecido que con un simple pegote de yeso sujetaban la tablilla y las piezas de porcelana para su enrollado (Fig. 12, B). No en vano, estas piezas, cables y una bombilla, han podido ser recuperados de la superficie del edificio. Esto evidentemente indica la presencia de alumbrado a lo largo del corredor central tal y como es común en los refugios públicos. A este respecto, 

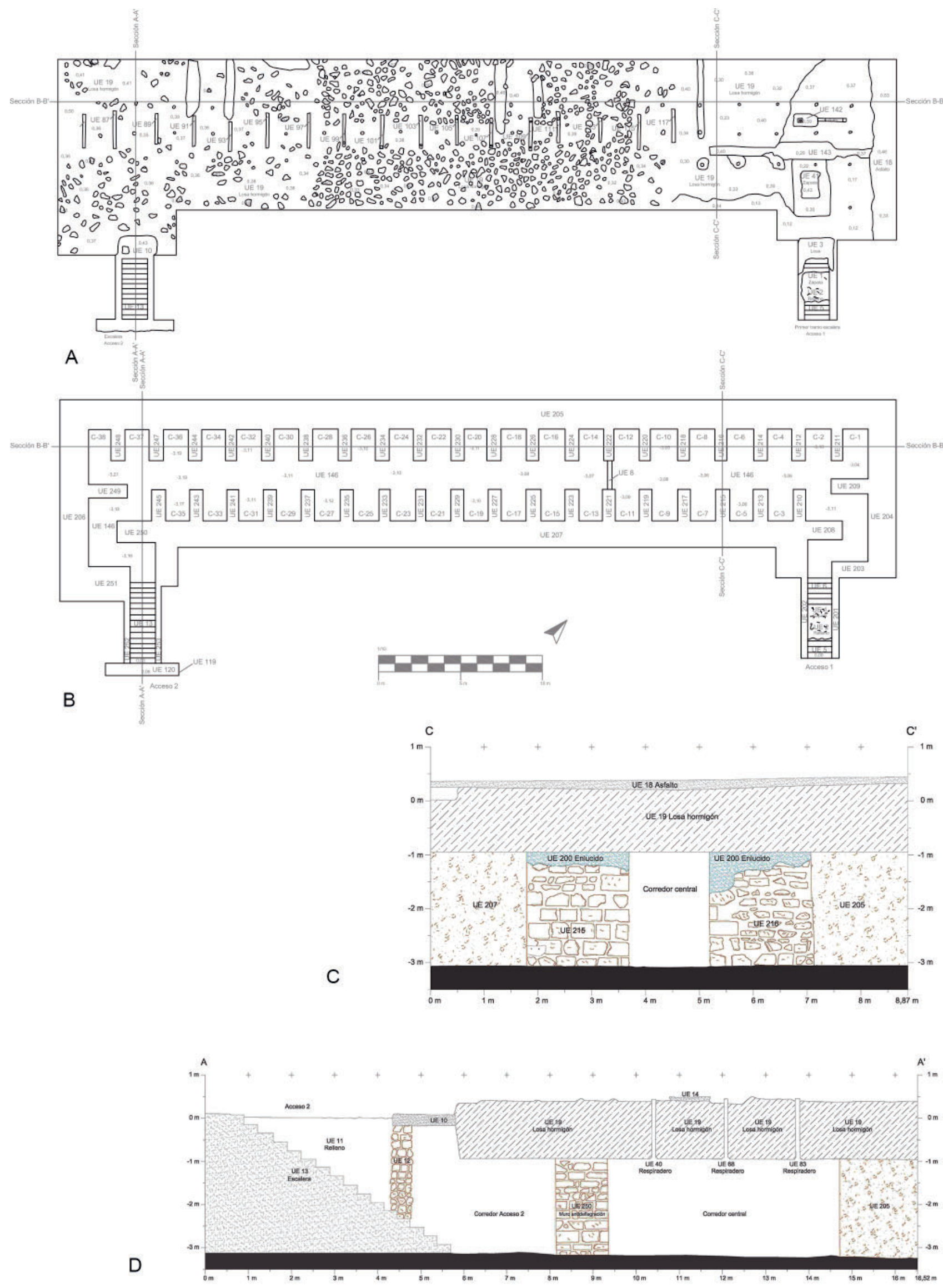

Figura 10: A. Plano planta exterior del refugio con losa de hormigón. B. Plano planta interior del refugio. C. Plano sección C-C con interior, pilares, corredor central y losa. D. Plano sección A-A con escalera y acceso sur (M. Lumbreras y R. Falcó). 

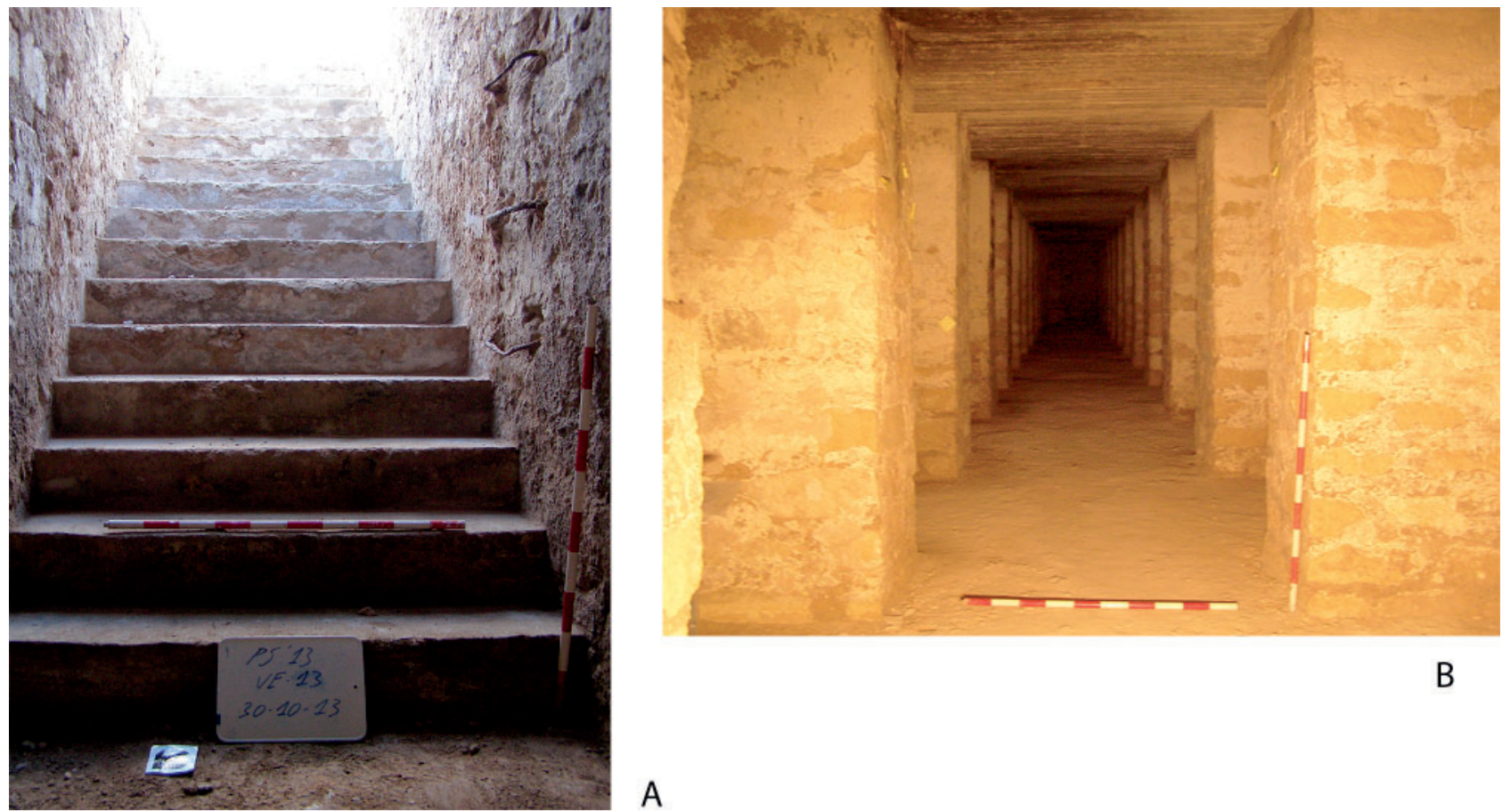

Figura 11: A. Fotografía escalera sur de acceso al refugio (M. Lumbreras). B. Fotografía Corredor central en interior del refugio (M. Lumbreras).

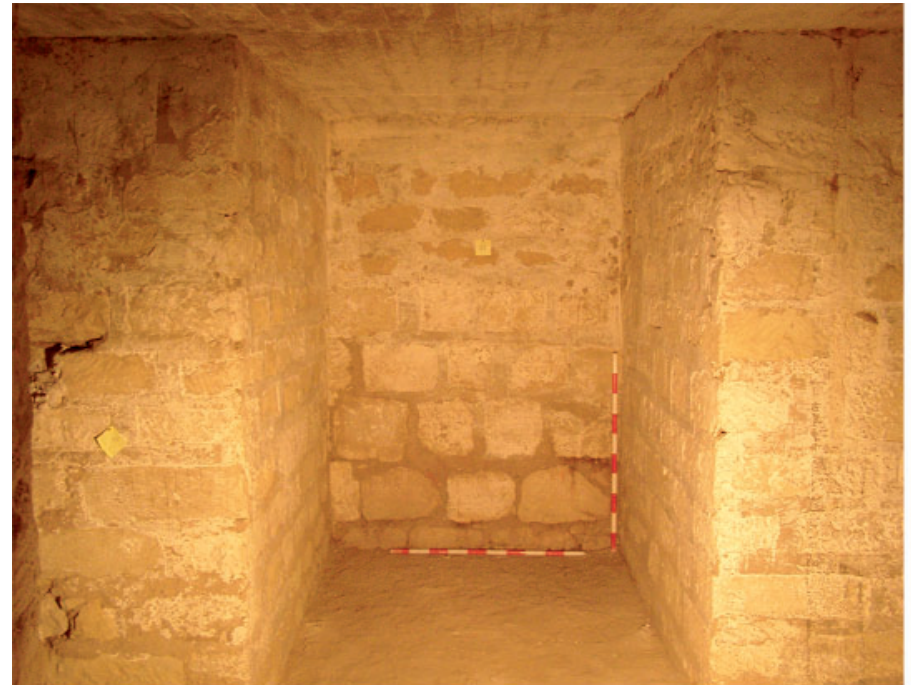

A

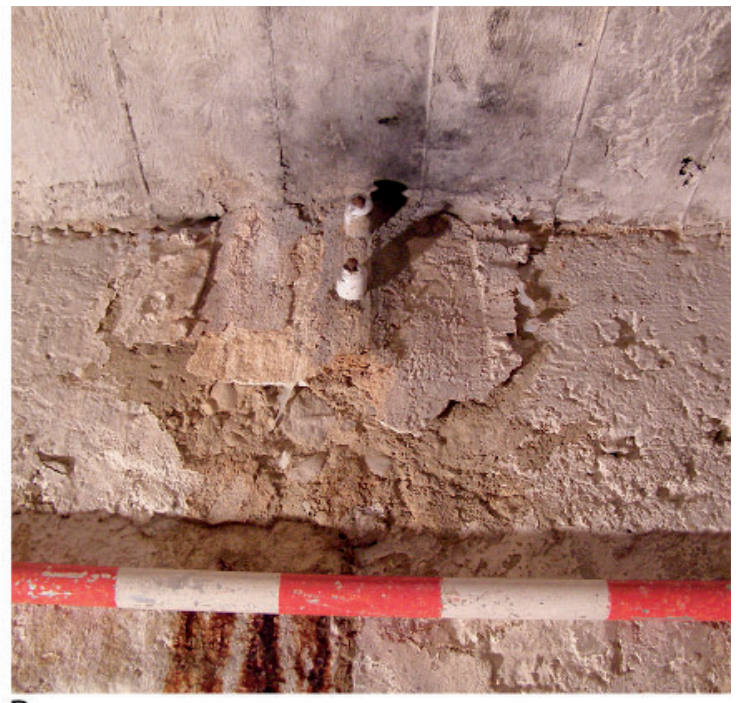

B

Figura 12: A. Fotografía de celda o cubículo (M. Lumbreras). B. Fotografía jícaras de porcelana para el paso del cableado del interior del refugio

queremos añadir que también se recomendaba para los refugios la disposición de un equipo autónomo, no sólo de electricidad, sino también de ventilación, en caso de que las salidas del refugio resultaran taponadas por los bombardeos (AMA Arm.19 Leg. 30/2). No queremos aquí enumerar una a una cual era la equipación completa de un refugio, pero hay que decir que se conserva numerosa documentación donde con facturas y presupuestos, no sólo sabemos cual era el material eléctrico necesario, sino incluso los precios a los que ascendían dichas instalaciones. Restos de estos equipos eléctricos o de ventilación, puede que sean dos vigas insertadas en las paredes de los cubículos 14 y 28 en un espacio intermedio tal y como se cita en las recomendaciones, y que interpretamos servirían para la sujeción de la maquinaria o generadores de electricidad o ventilación. Como elemento de mobiliario, aparte de los restos de estantes, destacan las improntas de yeso de 20 bancos, ya desaparecidos, dispuestos en el fondo de las celdas con cabida para 3 ó 4 personas, y que como vemos en los rótulos, quedarían reservados para niños y ancianos. Debemos decir, que durante la 
intervención fueron encontrados al fondo también de 20 cubículos, amontonamientos de tierra que viendo su contenido material, tal como elementos caídos de paredes o fragmentos de respiraderos, interpretamos como fruto de una limpieza superficial del refugio posterior a su uso efectivo.

Para terminar con el interior, añadiremos que el espacio disponible sería de $214 \mathrm{~m}^{2}$, con una longitud total de 47 metros de lado a lado y una anchura máxima de 5'40 metros en la parte del pasillo central. Puesto que contamos con esos datos relativos a las medidas de espacio disponible del interior, no queríamos pasar por alto o dejar de comparar las cifras de capacidad o aforo dadas por las distintas fuentes antes mencionadas, y que recordemos, nos daban distintas cifras que iban desde las 2500 personas, dato ofrecido con el refugio todavía en construcción, a las 1200 ó 1000, ofrecido ya con el edificio terminado. Contando con el espacio útil o autorizado tras los muros antideflagración de las entradas, tendríamos una superficie de casi $211 \mathrm{~m}^{2}$. Teniendo en cuenta las recomendaciones dadas por la Junta de Defensa Pasiva sobre el aforo en los refugios públicos, que cifraba la capacidad en 4 personas por metro cuadrado (AMA. Arm.19 Leg. 30/2) la capacidad óptima o ideal, que no real, para el Refugio de la Plaza de Séneca sería de unas 844 personas, cifra algo alejada, de las aportadas por la diferente documentación. Queremos señalar también el dato ofrecido por la Junta de Defensa Pasiva, que estimaba los costes de los refugios de losa de hormigón en función de su capacidad, con una estimación, según consta de 225 pesetas «por persona albergada», cifra también que consideramos muy alejada de la realidad si la comparamos con presupuestos existentes, costes y capacidades de otros refugios de su mismas sus características (AMA Arm.19 Leg. 32/3). Por este desfase de cifras, no hemos visto acertado aquí, aventurar el hipotético coste de su construcción.

\subsection{Los Sindicatos y El RefUgio de Plaza SÉNECA}

La razón por la que queremos dedicar unas líneas al papel que jugaron los sindicatos en la construcción del refugio, no es otra que el hallazgo o presencia de ciertos grafitis que muestran las siglas del sindicato socialista UGT, Unión General de Trabajadores, y del anarcosindicalista CNT, Confederación Nacional del Trabajo, junto a otros grafitis que puede que hagan mención a los propios trabajadores, o a quien detentaba el control sobre el refugio. En este sentido, cabe recordar que el mismo año en que comienza la guerra, y en diciembre 1936, el Sindicato de la Construcción de la CNT de Alicante se hace con el control de las todas las industrias cerámicas existentes en Alicante como la Santo Tomás, San José o Cerámicas Sol, que pasaron a llamarse «Industria Cerámica Socializada» (AMA. Arm.19 Leg. 30/17 bis). Su socialización resultó clave en la construcción de refugios, puesto que su producción pasó a destinarse a las urgentes obras de defensa. Este hecho queda patente en las distintas facturas remitidas a la Junta de Defensa Pasiva, donde vemos la provisión del material necesario para la construcción de refugios. Un ejemplo, es una factura de material destinado al refugio de la Calle Konsomol, hoy calle Padre Mariana, con fecha del 25 de agosto de 1937 y con sello único de la CNT (Fig. 13). También con sello estampado de la UGT contamos con una factura de la farmacia Pérez Devesa, dónde en este caso, el control sobre el negocio lo detenta este sindicato (AMA, Leg. 30/17 Bis). Aunque sea la CNT en estos momentos, quien tenga el control sobre las industrias más importantes de la ciudad, es la Federación de sindicatos de la UGT la que más ramos tenía, y por tanto quien contaba con más miembros, con un total de 82 sindicatos, siendo el Sindicato de Edificaciones de la Federación uno de los que tenía más afiliados, contando con 1260 miembros sólo en la ciudad de Alicante (Ramos Pérez, 1972, 325). Desde los primeros momentos de la contienda, la participación de la UGT en la defensa activa y pasiva en la provincia queda patente con el llamamiento o reclutamiento de voluntarios para los batallones de Obras y Fortificaciones. Ejemplo gráfico, lo encontramos en su propio órgano de difusión el periódico Bandera Roja, donde en junio de 1937 se invita al alistamiento en los batallones de Obras y Fortificaciones (AMA, Bandera Roja, 2-6-1937-Fig.14-). Hay que tener muy en cuenta, según consta en las actas de la Defensa Pasiva, que no son estos batallones de voluntarios militarizados los que se encarguen de la construcción de los refugios, sino afiliados de los ramos de la construcción o edificaciones de la CNT y UGT. Cabe señalar, que en ningún caso de manera voluntaria, quedando los mencionados batallones encargados de las obras de defensa de la costa como búnkeres, posiciones de artillería, o casamatas de vigilancia. Aunque no cabe duda de la aportación sindical, la relación con la Junta de Defensa Pasiva no siempre fue del todo buena. En febrero de 1938 por ejemplo, en las actas de la Junta de Defensa celebrada ese día, se pone en conocimiento un oficio de la Sección de Técnicos de la CNT y UGT, en la que manifiestan encontrarse dispuestos a prestar su colaboración en la construcción de los refugios públicos, al tiempo que en el mismo documento se da cuenta de la presentación de nuevos jornales del Control de obreros del ramo de la construcción, con un aumento del 90\% «sobre sus actuales salarios», además de la exigencia de un $10 \%$ en concepto de control sobre las obras. No sabemos cómo acabaría este asunto, pero parece que la Junta de Defensa Pasiva pone de manifiesto la imposibilidad de terminar las obras de refugios en proyecto ante estas nuevas condiciones, planteando la posibilidad de dirigirse al Comandante Militar de la Plaza de Alicante, para que militarice a los obreros del ramo, tal y como veíamos en los batallones de obras y fortificaciones. A este respecto, parece que incluso la Junta llega a sugerir el uso de presos para ciertos trabajos puntuales (AMA, Arm.19 Leg. 30/5). 


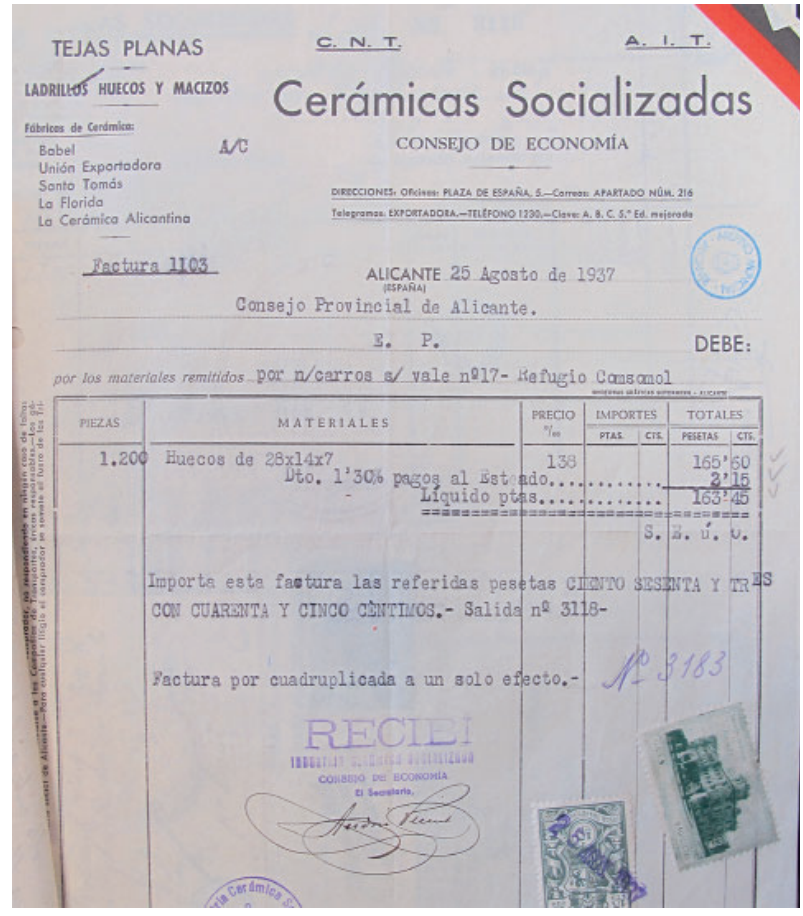

Figura 13: Factura de material de las Industrias Cerámicas Socializadas para la construcción de refugio (AMA. Arm.19 Leg. 30/17 bis).

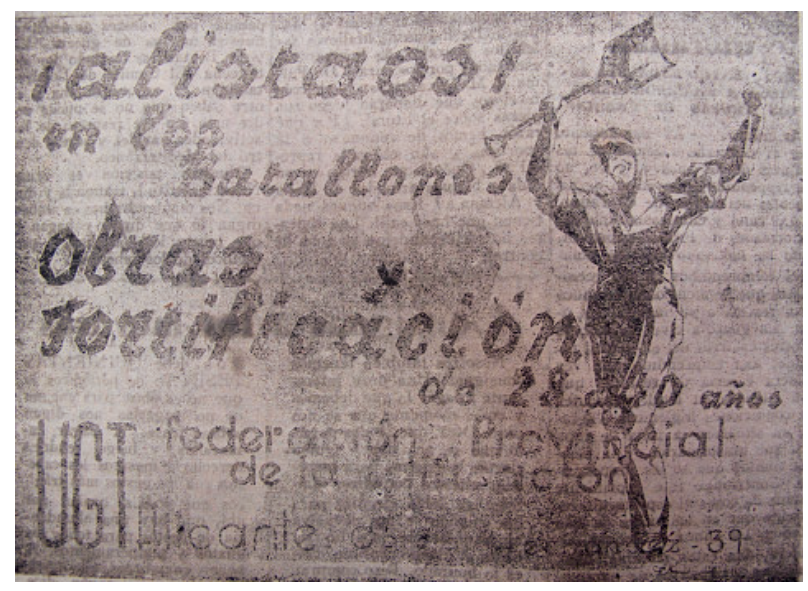

Figura 14: Anuncio aparecido en la prensa alicantina en julio de 1937 (AMA, Bandera Roja 2-6-1937).

Un año antes de dichas exigencias sobre aumentos de sueldos, y para el refugio de la Plaza de Séneca, contamos con un valioso documento para conocer los nombres de los obreros que participaron en su construcción, además del sueldo que recibían por jornada de trabajo (AMA, Arm.19 Leg. 30/17 Bis). El documento pertenece a la relación de nóminas y facturas llegadas a la Junta de Defensa Pasiva. En concreto son las nóminas referidas a los trabajos realizados en agosto de 1937, a razón de 14 pesetas para el encargado y 10 para los peones por jornada trabajada. Los nombres y relación de puestos son: José Bevía como responsable y quien firma la nómina, junto a once peones cuyos nombres son: José Canls, Fernando Duran, Ramón

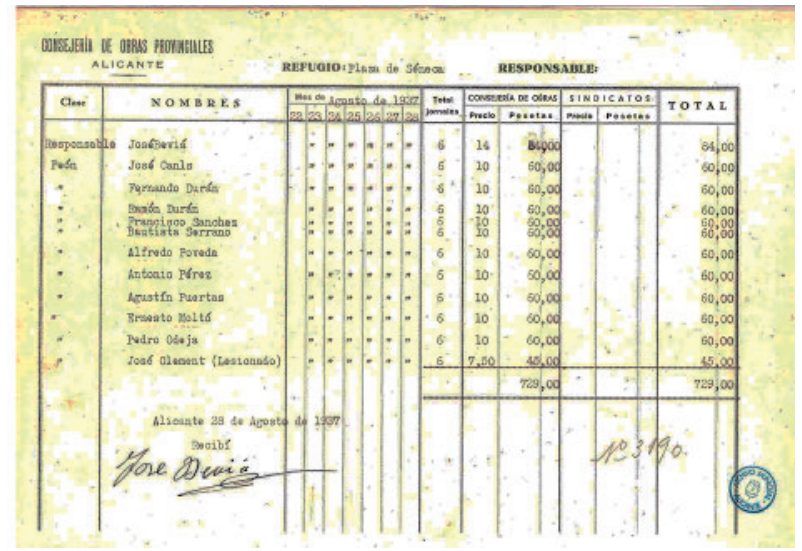

Figura 15: Documento con las nóminas de los obreros del refugio de la Plaza de Séneca (AMA Arm. 19 Leg. 30/17 Bis).

Duran, Francisco Sánchez, Bautista Serrano, Alfredo Poveda, Antonio Pérez, Agustín Puertas, Ernesto Moltó, Pedro Odeja, y por último José Clement, el cual, según el documento aparece como lesionado (Fig.15). Debemos señalar, que hemos comparado algunas de las iniciales encontradas en grafitis realizados en el techo del refugio probablemente con una vela, hallando tan solo tres coincidencias con los obreros de la nómina, concretamente la del responsable de las obras y dos de los peones. El número de iniciales, 22 en total, nos inclina a pensar que probablemente sólo se deba a una coincidencia.

Aunque con ciertas dudas también, hemos querido relacionar estos grafitis, encontrados en sendas entradas del refugio, con los posibles obreros. Puesto que contamos en un cubículo también en el techo y a cremación, con otro que muestra las siglas UGT CNT juntas (Fig. 16). Este dato es reseñable, puesto que en otros casos y sobre paredes, tenemos solo las siglas CNT o AIT de manera única. Podemos deducir por tanto, que este grafiti conjunto debe haberse realizado a partir de octubre de 1937, momento en que la situación de ambos sindicatos cambia por completo, creándose el llamado Comité de Enlace CNT-UGT en la ciudad de Alicante, aceptando la decisión de ambos sindicatos de ir de la mano, o de unificarse tomada por sus órganos o Comités Nacionales (Ramos Pérez, 1972, 135). El acuerdo es celebrado, y ampliamente comentado por la prensa local con numerosos artículos de opinión e incluso viñetas (AMA, Nuestra Bandera 3-11-1937-Fig.17-). El grafiti encontrado sobre el techo de hormigón del refugio, muestra a las claras la colaboración de ambos sindicatos ya en su construcción o en su control, lo que supondría las labores de custodia y mantenimiento. Este control que vemos explicitado en un pequeño grafiti a lápiz, muestra la tutela ejercida, suponemos que sobre el edificio, por parte de la CNT. Para terminar, otra de las siglas aparecida y relacionada también con la CNT, que tenemos de manera aislada sobre uno de los muros, son las siglas AIT o Asociación Internacional de los Trabajadores, asociación a la que se encontraba adherida la CNT y 


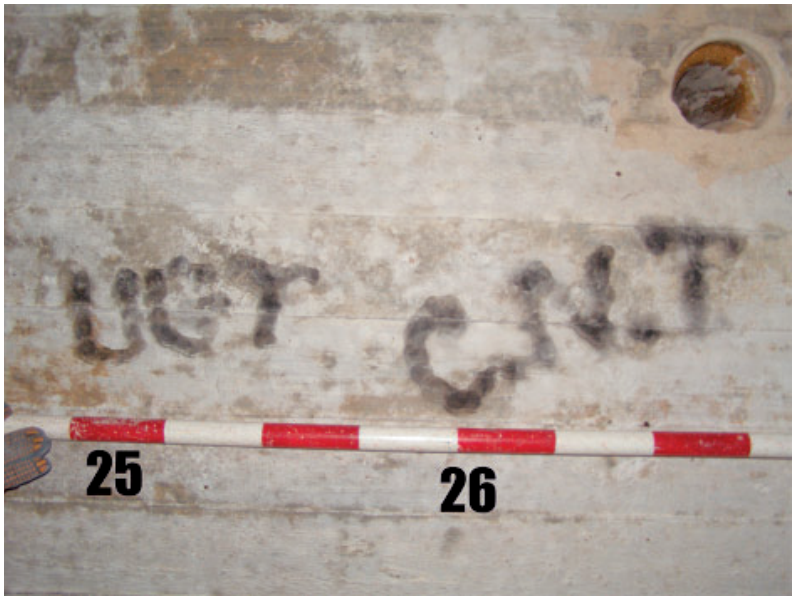

Figura 16: Fotografía de grafitis con las siglas UGT CNT sobre techo de cubículo (M. Lumbreras).

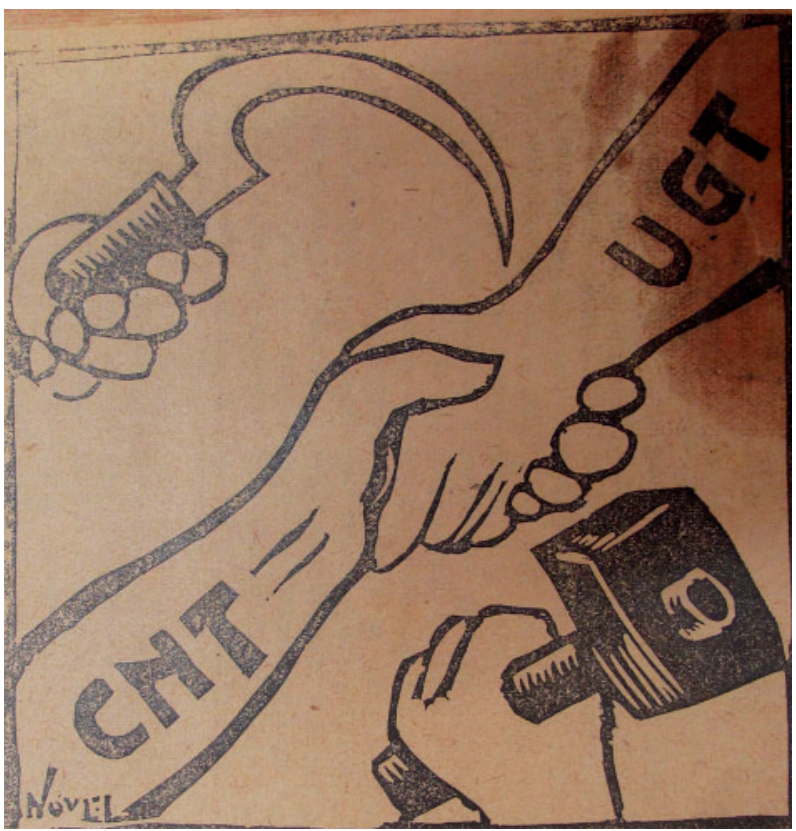

Figura 17: Viñeta publicada en la prensa alicantina en noviembre de 1937 (AMA Nuestra Bandera 3-11-1937).

siglas que en repetidas ocasiones aparece en documentos y rótulos junto a los del sindicato anarquista.

\subsection{LOS RÓTULOS Y GRAFITIS}

Como elemento originario y propio del refugio, hemos documentado durante el trabajo de campo mediante calco y fotografía, los 27 rótulos pintados en azul añil sobre las paredes de las escaleras, corredores y cubículos. Todos ellos dispuestos en las caras o lados de las paredes, conforme a la dirección de entrada de las personas que pudieron utilizarlo (Fig. 18). Hemos recogido en las láminas una selección de los más característicos, puesto que en la mayoría de ellos el motivo o mensaje se repite en algunos casos varias veces. En primer lugar, destacan por temática y

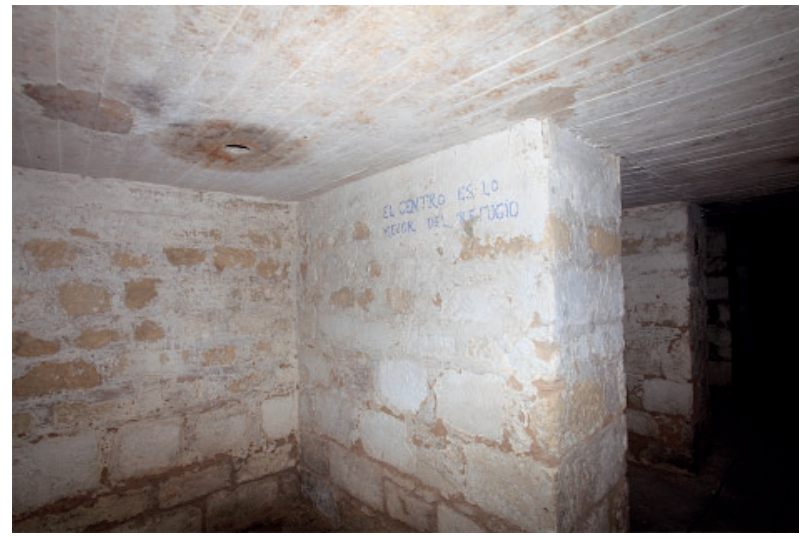

Figura 18: Fotografía interior del refugio con rótulo en pared (M. Lumbreras).

localización, dos rótulos hallados en ambas entradas del refugio con sendas advertencias hacia los espías. Uno de ellos, se encuentra parcialmente perdido, el pintado en el corredor de acceso 1 que muestra el dibujo de un ojo, y que conserva las letras OJ (Fig. 19, A). Por otro lado, en el corredor de acceso 2, tenemos el dibujo mejor conservado de una oreja con la advertencia de «el espía oye» (Fig. 19, B). Suponemos que, aunque esté perdido, la advertencia del primer
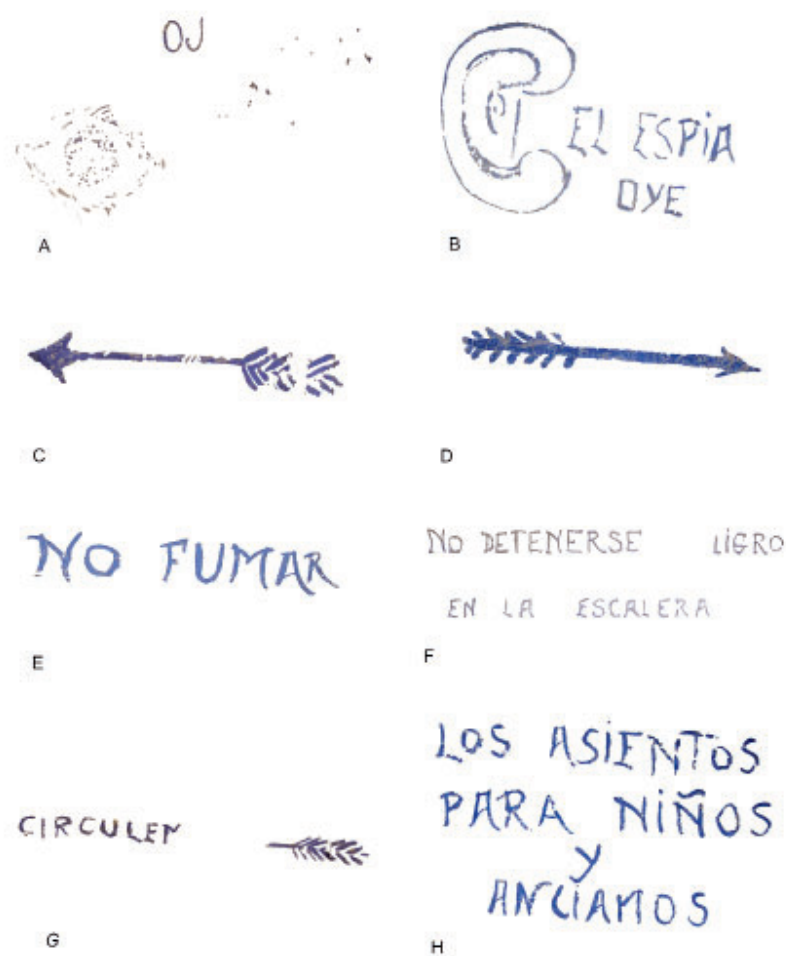

Figura 19: A. Rótulo pintado en corredor central del refugio. B. Rótulo pintado en pared de corredor de acceso norte. C. Rótulo pintado en pared corredor de acceso sur. D. Rótulo con flecha de dirección pintada en corredor de entrada. E. Rótulo con flecha de dirección pintada en corredor de entrada. F. Rótulo pintado en corredor central. G. Rótulo Pintado en escalera de acceso sur. H. Rótulo pintado en cubículo 29. 


\section{CEDER LOS ASIENTOS A L 0 S \\ MIŃOS Y ANCIANOS \\ A

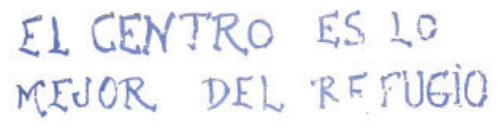 \\ B

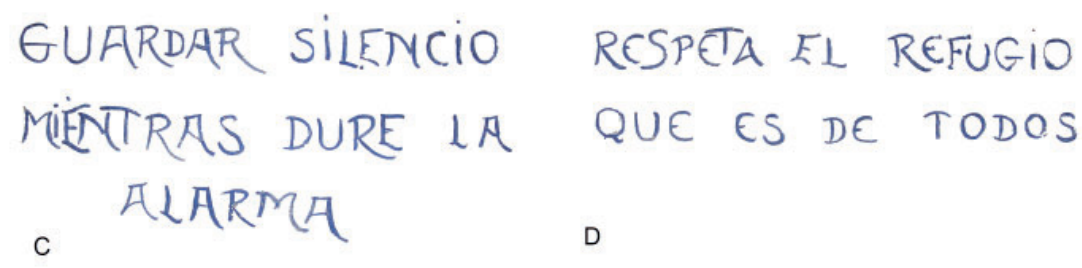

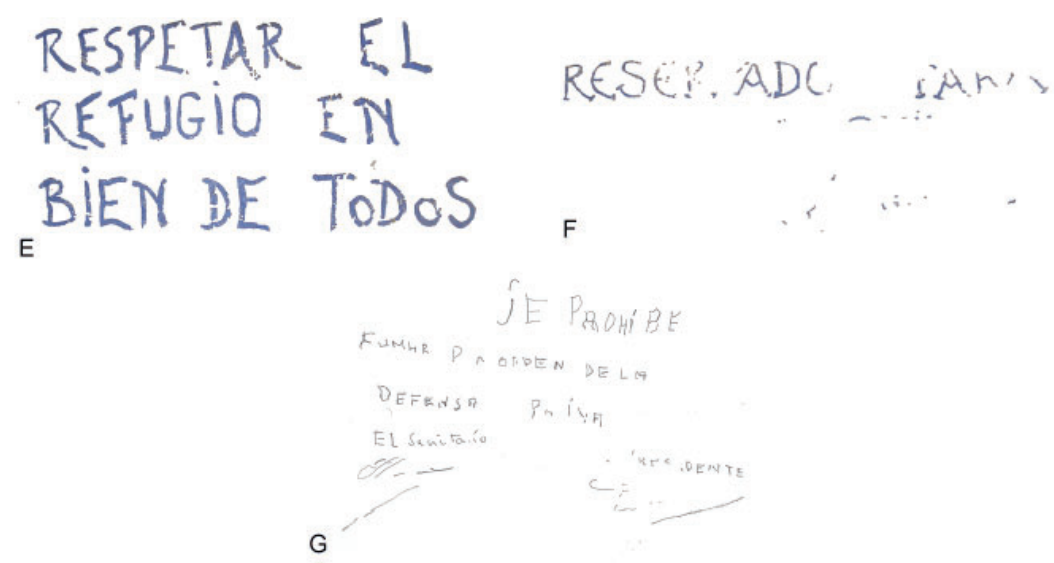

Figura 20: A. Rótulo pintado en corredor central. B. Rótulo pintado en corredor de acceso norte. C. Rótulo pintado corredor de acceso sur. D. Rótulo pintado en corredor central. E. Rótulo pintado en corredor central. F. Rótulo pintado en cubículo n ${ }^{\circ}$ 1. G. Grafiti pintado en cubículo.

rótulo sería exactamente la misma que en el segundo, es decir, - ojo el espía oye o el espía ve -. Al hilo de estos dos últimos rótulos, es reseñable la preocupación en tiempos de guerra del fenómeno del espionaje, sabotaje, o de la llamada quinta columna. Aquí observamos como ambas advertencias ocupan un lugar preferente del refugio, siendo los primeros en ser vistos una vez se accede al interior. Estos avisos, no solo los encontramos en los refugios antiaéreos, sino que también son bien conocidos y muy comunes en la prensa y en la variada cartelería propagandística del momento, incluso como en nuestro rótulo, usando como motivo recurrente la figura de la oreja.

El resto de rótulos, podemos clasificarlos por un lado, entre aquellos de señalización como las numerosas flechas, 6 en total, que indican la dirección a seguir (Fig. 19, C, D). Por otro lado, tenemos enunciados con prohibiciones, como los repetidos en 7 ocasiones y omnipresentes de no fumar (Fig. 19, E). Contamos también, con aquellos que prohíben detenerse en la escalera y pasillos, presentes en ambos accesos y en corredores (Fig. 19, F, G). Ya como recomendaciones, hay una serie de rótulos en los que se insta a ceder los asientos a los niños y ancianos, o aquel que invita a pasar al centro del refugio como lugar más seguro del edificio (Fig. 20, A; Fig. 20, B). Al tiempo, un único rótulo conmina a guardar silencio durante la alarma de bombardeo (Fig. 20, C). Curiosos resultan también, los rótulos que apelan al civismo de los usuarios, a través de frases como «respetar el refugio en bien de todos» o «es de todos» (Fig. 20, D, E). Para terminar con los rótulos, y encontrándose incompleto, tenemos situado en el primer cubículo junto al acceso norte, un anuncio del que sólo se ha podido identificar las letras «reserv-do para» (Fig. 20, F). Su localización junto a la entrada, los restos de yeso de un portón, además de las recomendaciones de la Junta de Defensa Pasiva, podrían indicar que la palabra que falta hace referencia a una enfermería o servicio sanitario. Como elemento imprescindible podemos encontrar esta clase de rótulos y señalizaciones en numerosos refugios tanto de la provincia, como en otras ciudades cercanas como Albacete o Alcoy (Selva Iniesta, 2000, 40-49; Beneito Lloris, 2007).

Al igual que los rótulos, tenemos plasmados y repartidos por las paredes y techos del refugio, un total de 66 grafitis de distinta tipología según su factura; ya fuera por cremación, incisos o simplemente hechos a carboncillo o lápiz. Su contenido es principalmente onomástico con numerosos nombres, en firmas, 
completos, o sólo con las iniciales. No faltan tampoco los grafitis de carácter político sindical con referencias a la CNT, UGT o AIT, y que comentamos de manera detallada en el apartado dedicado al papel de los sindicatos. Uno de estos grupos que hemos denominado como grafitis a cremación, se encuentran en su mayoría localizados en ambas entradas del refugio. Realizados probablemente con la lumbre de una vela, muestran nombres a partir de iniciales y algunos apellidos. En total son 22 nombres que tipológicamente guardan relación, como ya hemos dicho con el grafiti encontrado en uno de los cubículos en el que figuran las siglas UGT CNT (Fig. 16).

Otro tipo de grafitis son los realizados a partir de incisiones, o los realizados a lápiz que juntos forman un grupo de 33 en total. Entre estos realizados a lápiz o carboncillo, destaca o sorprende por su pequeño tamaño y su localización al fondo de un cubículo, el grafiti en el que se recoge la prohibición de fumar por parte de la Junta de Defensa Pasiva (Fig. 20, H), grafiti firmado no sólo por el sanitario sino también, según queda escrito, por el «Presidente», no sabemos si de la Junta de Defensa Pasiva, o de otro organismo, puesto que las firmas no parecen coincidir. Suponemos que dicha prohibición encontrada en repetidos rótulos, queda más que formalizada como documento pero en forma de grafiti.

Cabe señalar los nombres propios repartidos por todo el refugio, algunos de los cuales se pueden reconocer con facilidad, como el de Vicente Balagué, Teresita, María, Asunción o los apellidos Lexere o Botas. Otros grafitis son cifras e indicaciones en palabra o en forma de aspas, signos y palabras, posiblemente realizados durante el proceso de construcción del refugio. Por último tenemos una serie de dibujos a carboncillo, que si bien algunos son reconocibles, otros sin embargo son de difícil identificación, y digamos que de libre interpretación.

A continuación mostramos la relación total de rótulos y localización dentro de la construcción.

\section{RÓTULOS DEL REFUGIO PLAZA DE SÉNECA}

\begin{tabular}{|c|c|c|}
\hline $\mathrm{N}^{\mathrm{o}}$ & Texto o contenido & Localización \\
\hline 1 & «PELIGRO NO DETENERSE -N - ESCALERA» & Escalera de acceso 1 \\
\hline 2 & Restos de probable indicación de dirección o flecha & Escalera de acceso 1 \\
\hline 3 & «CIRCULEN» & Escalera de acceso 1 \\
\hline 4 & $\ll \mathrm{OJ}---\ll$ & Corredor de acceso 1 \\
\hline 5 & Flecha o indicación de dirección & Corredor de acceso 1 \\
\hline 6 & Flecha o indicación de dirección & Corredor de acceso 1 \\
\hline 7 & Flecha o indicación de dirección & Corredor de acceso 1 \\
\hline 8 & «EL CENTRO ES LO MEJOR DEL REFUGIO» & Corredor de acceso 1 \\
\hline 9 & «RESER-ADO PARA —- «. Restos de letras perdidas. & Cubículo 1 \\
\hline 10 & «NO FUMAR» & Cubículo 2 \\
\hline 11 & «NO FUMAR» & Corredor central, entre cubículos 4 y 6. \\
\hline 12 & «CEDER LOS ASIENTOS A NIÑOS Y ANCIANOS» & Cubículo 6 \\
\hline 13 & «NO FUMAR» & Cubículo 5 \\
\hline 14 & «NO FUMAR» & Corredor central entre cubículos 8 y 10 \\
\hline 15 & «NO FUMAR» & Corredor central entre cubículos 11 y 13 \\
\hline 16 & »CEDER LOS ASIENTOS A LOS NIÑOS Y ANCIANOS» & Corredor central entre cubículos 20 y 22 \\
\hline 17 & «NO FUMAR» & Cubículo 21 \\
\hline 18 & «RESPETAR EL REFUGIO EN BIEN DE TODOS» & Cubículo 26 \\
\hline 19 & »LOS ASIENTOS PARA NIÑOS Y ANCIANOS» & Cubículo 29 \\
\hline 20 & «NO FUMAR» & Cubículo 32 \\
\hline 21 & «RESPETA EL REFUGIO QUE ES DE TODOS» & Cubículo 35 \\
\hline 22 & $\begin{array}{l}\text { «LOS ASIEN - S SON -REFERI - — LOS NIÑOS Y } \\
\text { ANCIANOS» }\end{array}$ & Corredor de acceso 2 \\
\hline 23 & «GUARDAR SILENCIO MIENTRAS DURE LA ALARMA» & Corredor de acceso 2 \\
\hline 24 & »EL ESPIA OYE». Dibujo de oreja. & Corredor de acceso 2 \\
\hline 25 & $\begin{array}{l}\text { «NO SE - TENG-» } \\
\text { Dibujo de flecha }\end{array}$ & Corredor de acceso 2 \\
\hline 26 & $\begin{array}{l}\text { «CIRCULEN» } \\
\text { Dibujo de flecha }\end{array}$ & Corredor de acceso 2 \\
\hline 27 & «NO DETENERSE -LIGRO EN LA ESCALERA» & Escalera de acceso 2 \\
\hline
\end{tabular}


GRAFITIS POR CREMACIÓN EN EL REFUGIO

\begin{tabular}{|c|c|c|}
\hline $\mathrm{N}^{\mathrm{o}}$ & Texto o contenido & Localización \\
\hline 1 & «F. ANTON» & Techo corredor acceso 1 \\
\hline 2 & «JPC» & Techo corredor acceso 1 \\
\hline 3 & » FMO» & Techo corredor acceso 1 \\
\hline 4 & $»$ F.J.P.» & Techo corredor acceso 1 \\
\hline 5 & «J.P.C.» & Techo corredor acceso 1 \\
\hline 6 & «G.P.E.» & Techo corredor acceso 1 \\
\hline 7 & » F.J.P.» & Techo corredor acceso 1 \\
\hline 8 & $\ll U-\ll$ & Techo corredor acceso 1 \\
\hline 9 & «J. R. M.» & Techo corredor acceso 1 \\
\hline 10 & «S.C. $-\ll$ & Techo corredor acceso 1 \\
\hline 11 & «G.P.E» & Techo corredor acceso 1 \\
\hline 12 & «BURO» & Techo corredor acceso 1 \\
\hline 13 & «J.B.S.» & Techo corredor acceso 1 \\
\hline 14 & «G.P.E.» & Techo corredor acceso 1 \\
\hline 15 & «A.O.L.» & Techo corredor acceso 1 \\
\hline 16 & «E.M.S.» & Techo corredor acceso 1 \\
\hline 17 & «A.R.E.» & Techo corredor acceso 1 \\
\hline 18 & «--« texto Indeterminado & Techo corredor acceso 1 \\
\hline 19 & «J.F.-« & Techo corredor acceso 2 \\
\hline 20 & «J.P.P.» & Techo corredor acceso 2 \\
\hline 21 & «J.C.C.» & Techo corredor acceso 2 \\
\hline 22 & «F.R.R.» & Techo corredor acceso 2 \\
\hline 23 & «E.P.V.» & Techo corredor acceso 2 \\
\hline 24 & $\langle\mathrm{~N}-\rangle$ & Techo corredor acceso 2 \\
\hline 25 & «UGT» & Cubículo 6 \\
\hline 26 & «CNT» & Cubículo 6 \\
\hline 27 & «AIT» & Cubículo 5 \\
\hline
\end{tabular}

\section{GRAFITIS A LÁPIZ, CARBONCILLO E INCISOS EN EL REFUGIO}

\begin{tabular}{|c|c|c|c|}
\hline $\mathrm{N}^{\mathrm{o}}$ & Texto o contenido & Técnica & Localización \\
\hline 1 & Nombre indeterminado & Lápiz & Acceso escalera 1 \\
\hline 2 & Nombre indeterminado & Lápiz & Acceso escalera 1 \\
\hline 3 & $\ll 18,21 »$ & Inciso & Corredor acceso 1 \\
\hline 4 & «CD LEXERE» & Lápiz & Corredor acceso 1 \\
\hline 5 & $\ll \mathrm{Ma}--\ll$ & Lápiz & Corredor acceso 1 \\
\hline 6 & «CNT» & Carboncillo & Cubículo 2 \\
\hline 7 & $\begin{array}{l}\text { «Se prohíbe fumar por orden de la defensa — pa(s)i va } \\
\text { El sanitario (firma) El Presidente (firma)» }\end{array}$ & Lápiz & Cubículo 4 \\
\hline 8 & Cifras o números & Lápiz & Corredor entre cubículos 3 y 4 \\
\hline 9 & «AIT» & Carboncillo & Cubículo 1 \\
\hline 10 & Dibujo de cara & Lápiz & Cubículo 6 \\
\hline 11 & Aspa y $\mathrm{S}$ & Lápiz & Cubículo 6 \\
\hline 12 & «Anto-Antonia $--\ll$ & Lápiz & Cubículo 6 \\
\hline 13 & Dibujo indeterminado dentro de marco & Lápiz & Corredor entre cubículos 7 y 9 \\
\hline 14 & Firma de nombre indeterminado & Lápiz & Corredor entre cubículos 8 y 10 \\
\hline 15 & Letras con texto indeterminado & Lápiz & Corredor entre cubículos 9 y 11 \\
\hline 16 & Letras y líneas indeterminadas & Lápiz & Cubículo 11 \\
\hline 17 & Pictograma indeterminado & Lápiz & Corredor, entre cubículos 11 y 13 \\
\hline 18 & Líneas paralelas & Carboncillo & Corredor, entre cubículos 12 y 14 \\
\hline 19 & Marca indeterminada & Lápiz & Cubículo 14 \\
\hline
\end{tabular}




\begin{tabular}{|c|c|c|c|}
\hline 20 & Pictograma indeterminado & Lápiz & Corredor entre cubículos 13 y 15 \\
\hline 21 & «A» junto a letras indeterminadas & Lápiz & Corredor, entre cubículos 13 y 15 \\
\hline 22 & «Maria» & Lápiz & Corredor, entre cubículos 13 y 15 \\
\hline 23 & Dibujo indeterminado, posible avión & Lápiz & Cubículo 15 \\
\hline 24 & Marca indeterminada & Inciso & Corredor, entre cubículo 17 y 19 \\
\hline 25 & «Controlado» & Lápiz & Cubículo 20 \\
\hline 26 & Pictograma indeterminado, rectángulo y puntos & Lápiz & Cubículo 20 \\
\hline 27 & $\ll \mathrm{C}-\ll$ Nombre indeterminado & Lápiz & Cubículo 20 \\
\hline 28 & Letras «A» e indeterminadas & Inciso & Cubículo 20 \\
\hline 29 & Nombres o firma indeterminada & Lápiz & Cubículo 19 \\
\hline 30 & Dibujo o marca indeterminada & Lápiz & Cubículo 19 \\
\hline 31 & «AQUÍ» & Lápiz & Corredor entre cubículos 19 y 21 \\
\hline 32 & «ILL» & Lápiz & Cubículo 21 \\
\hline 33 & «CONTROLADO CNT PANSO L controlado» & Lápiz & Cubículo 22 \\
\hline 34 & «PANCHO» & Inciso & Cubículo 22 \\
\hline 35 & «TERESA» & Lápiz & Corredor entre cubículos 23 y 25 \\
\hline 36 & Aspa o «X» & Inciso & Cubículo 25 \\
\hline 37 & «Asunción-ía» & Lápiz & Cubículo 30 \\
\hline 38 & «Vicente Balague», firmado & Lápiz & Cubículo 38 \\
\hline 39 & Aspa o «X» & Lápiz & Cubículo 33 \\
\hline 40 & Grupo de letras inconexas e indeterminadas & Lápiz & Cubículo 35 \\
\hline 41 & «TERESITA» & Lápiz & Corredor de acceso 2 \\
\hline 42 & «LOM- - « & Inciso & Corredor de acceso 2 \\
\hline 43 & «GASPAR B» & Lápiz & Techo corredor de acceso 2 \\
\hline 44 & «BOTAS» & Lápiz & Techo corredor de acceso 2 \\
\hline
\end{tabular}

\subsection{MATERIALES ARQUEOLÓGICOS}

\subsubsection{Las monedas del refugio de la Plaza Séneca}

Es extraordinario el número y variedad de monedas encontradas en el propio suelo o pavimento de tierra apisonada del interior refugio, así como en amontonamientos de tierra encontrados en ciertos cubículos, y que pudieron ser fruto de una limpieza del mismo antes de su sellado definitivo (éstas se encuentran descritas de manera más detallada en el anexo correspondiente). Comenzando por la descripción de las más antiguas, tenemos un ejemplar de moneda de 5 céntimos emitidas por el Gobierno Provisional de 1870, de la llamada coloquialmente como perra chica, por el menor valor con respecto a la de 10 céntimos y en la que en el reverso podemos apreciar la figura de un león rampante con la cabeza vuelta sobre el escudo de España, y que la gente de su tiempo identificaba sarcásticamente con una perra (Fig. 21, A). En nuestra perra chica no podemos distinguir el relieve del anverso, cuyo motivo principal era la matrona Hispania sentada con rama de olivo. Estas monedas acuñadas en Barcelona, como podemos ver, tuvieron un largo recorrido siendo desmonetizadas en 1941, cuando son sustituidas por las monedas de céntimos de aluminio, uno de cuyos ejemplares precisamente hemos encontrado, aunque en un contexto bien distinto. Otras piezas también con largo recorrido, son las monedas emitidas en el reinado de Alfonso XII, una de ellas de 5 céntimos y una segunda de 10 céntimos (Fig. 21, B, C). Como las anteriores, son acuñadas en Barcelona y en ambas podemos ver la cabeza del rey a la derecha sin barba, y con la leyenda «Alfonso XII por la gracia de Dios». Por dibujo diámetro y peso, puesto que la marca de valor ha desaparecido, hemos apreciado que se trata de monedas de 5 y 10 céntimos acuñadas entre 1877 y 1879 para la de 5 céntimos, y en 1878 para la moneda de 10. (Calicó, Calicó y Trigo, 1994, 649).

Aunque contamos con un buen número de monedas de las que no hemos podido conocer ni valor ni procedencia, sí podemos decir que el mayor número de piezas son las emitidas por el Gobierno de la República precisamente durante los años de la Guerra Civil de cara a mitigar la escasez de moneda fraccionaria. Una de estas monedas acuñadas, fue la conocida por el color del latón con el que estaba hecha, como rubia, llamada también pesetas de Negrín, último Presidente de la República, y entonces Ministro de Hacienda. Parece que esta moneda tuvo que ser realizada en Castellón aunque con los troqueles, materiales y operarios de la Casa de la Moneda de Madrid, que en estos años de contienda convirtió su actividad en itinerante, trasladándose primero de Madrid a Castellón y más tarde a la localidad alicantina de Aspe conforme avanzaba el bando nacional. En nuestro caso, contamos con dos ejemplares muy deteriorados en los que apenas se distinguen en su anverso la figuras alegóricas de mujer de 

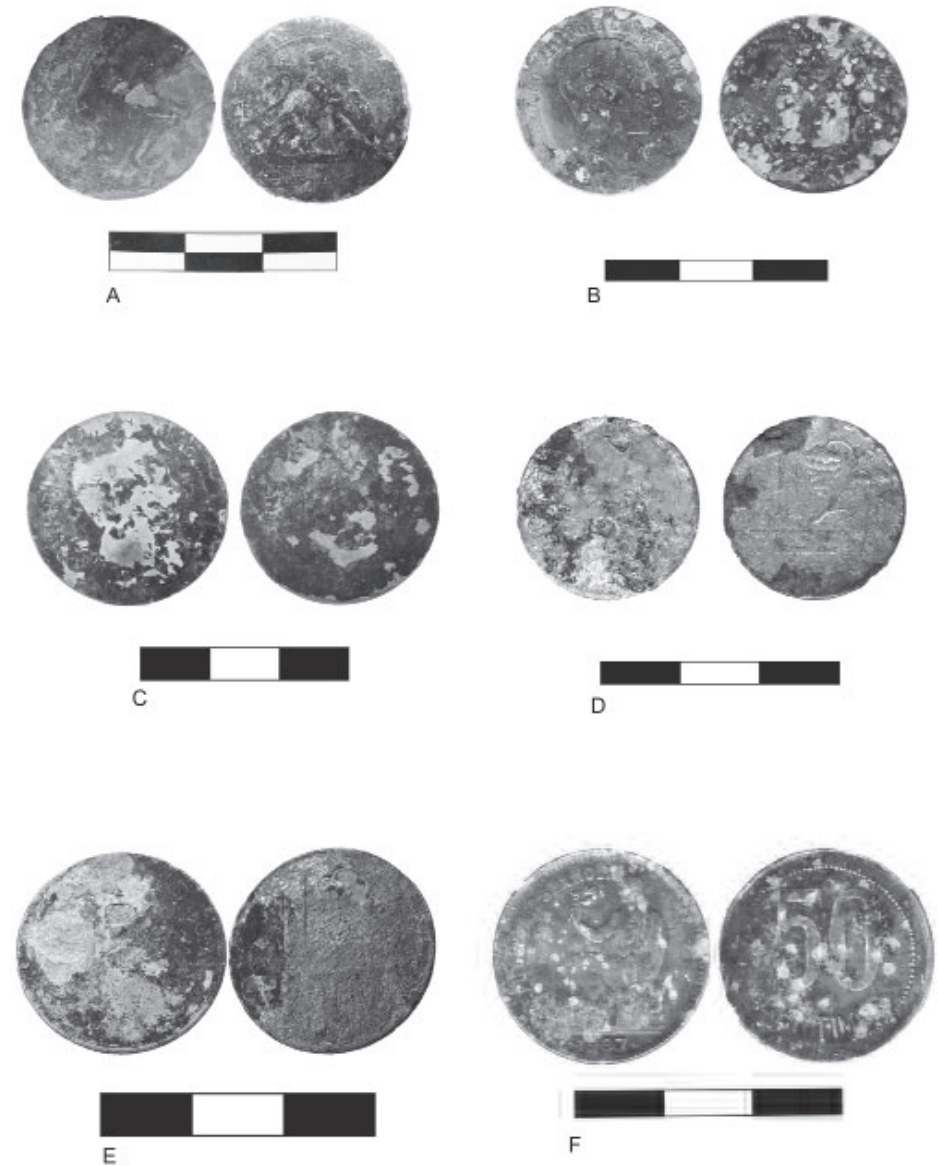

Figura 21: Monedas del Refugio de Plaza Séneca. A. Moneda de 5 céntimos del Gobierno Provisional. B. Moneda de 5 céntimos de Alfonso XII. C. Moneda de 10 céntimos de Alfonso XII. D. Moneda de 1 peseta de la Segunda República. E. Moneda de 1 peseta de la Segunda República. F. Moneda de 50 céntimos de la Segunda República.

la República, y con la marca de valor y representación de vid apenas apreciable en el reverso de una de las monedas (Fig. 21, D, E).

También realizadas en Castellón, y en el año 1937, encontramos dos monedas de 50 céntimos hechas en cobre, moneda ésta a la que se le atribuyen distintas variantes (Calicó, Calicó y Trigo, 1994, 848). En el anverso de la moneda se repite el motivo ya utilizado en las pesetas de plata de 1933, y en el que vemos de nuevo la figura alegórica de la Republica sentada y con rama de olivo en su mano, por lo que también era conocida como la del tío sentado. En el reverso y en orla, la marca de valor ocupa toda la parte central de la moneda (Fig. 21, F; Fig. 21, A).

Para completar el elenco de monedas republicanas acuñadas durante la Guerra civil, tenemos un ejemplar que bien pudo ser acuñado también en Castellón o en Aspe. En su anverso podemos ver el año de su emisión, así como la figura del libro de la ciencia rompiendo las cadenas, mientras que en su reverso vemos la marca de valor y una rama de trigo (Fig. 22, B). Se trata de la moneda de 25 céntimos de cobre de 1938, única emisión monetaria que pudo salir de Aspe, aunque como ya señalamos, con maquinaria y operarios de la Fábrica Nacional de Moneda y Timbre (García Gandía, 2010). Es reseñable, el hallazgo en el interior del refugio de una moneda de 25 céntimos del bando nacional, emitida en el año 1937 por la ceca de Viena. Su anverso muestra el yugo y el haz de flechas además de la leyenda España una grande y libre 1937 II año triunfal, mientras que en el reverso tenemos su marca de valor y el escudo de armas de los reyes católicos y rama de olivo (Fig. 22, C).Como decimos, estas monedas de cuproníquel y orificio central, tuvieron que ser realizadas en Austria por no disponer el bando nacional o Gobierno de Burgos de la infraestructura necesaria para su fabricación. (Corporales Leal, 2011, 183).

Más excepcional si cabe, es la presencia de una moneda de procedencia china probablemente de la dinastía Quing, y de la que podemos identificar en su reverso los sellos de su ceca, y en el anverso, casi ininteligible, la palabra o leyendas típicas en ideogramas chinos de estas piezas, es decir Tong bao o T'ung-pao, cuyo significado genérico en manchú es moneda o dinero (Fig. 22, D). Estas emisiones conocidas como Cash chino, provienen de la ceca de Yuwan (Boo-Yuwan), una de las dos existentes en Pekín. Lamentablemente su estado no nos permite asegurar su fecha o era, aunque por uno de los paralelos conservado en el museo Cerralbo de Madrid, como decimos, sí parece pertenecer a la era Quiang Long (Seco Serra, 2006, 151-167) emperador bajo la cual fue acuñada. Los ideogramas que se 

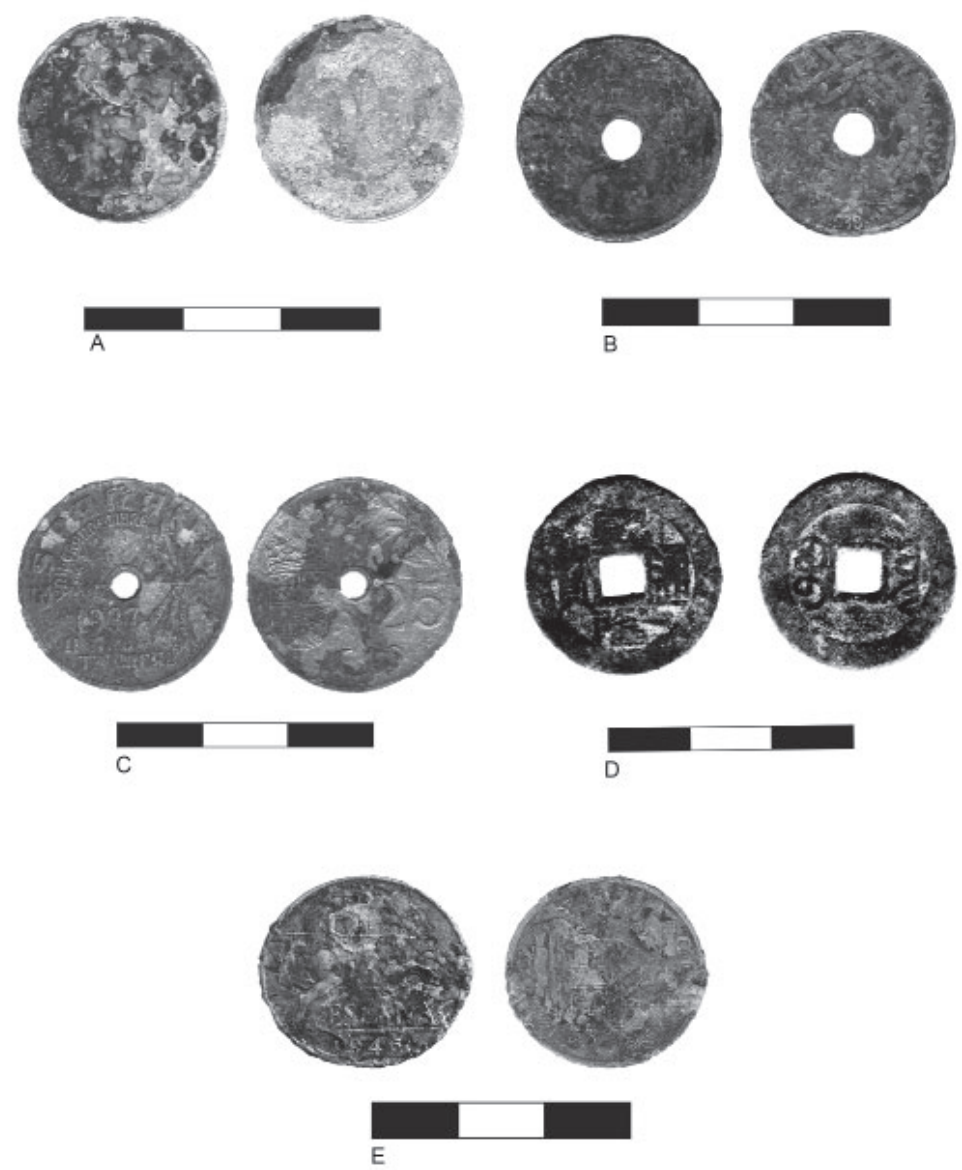

Figura 22: A. Moneda de 50 céntimos de la Segunda República. B. Moneda de 25 céntimos de la Segunda República. C. Moneda de 25 céntimos del bando Nacional. D. Moneda de cash chino. E. Moneda de 10 céntimos del Gobierno de Franco.

refieren a éste, guardan cierto parecido también con los de las monedas del Emperador Te-Tsung reinante entre 1875 y 1908 (Cuhaj y Michael, 2012, 239-241).

Por último, y encontrada, como habíamos señalado, en un contexto diferente al resto de monedas, o sea, en el relleno de escombros que dejaba cegada la escalera de uno de los accesos, se halla una moneda de 10 céntimos emitida ya por el Gobierno de Franco en el año 1945. En su anverso se representa a un jinete con lanza, inspirado en antiguos modelos íberos, la leyenda España junto a su año de emisión de 1945. En su reverso muestra la marca de valor y el escudo del régimen con el águila imperial, el yugo y el haz de flechas (Fig. 22, E). Realizadas en aluminio, esta moneda junto a la de 5 céntimos heredarían el apelativo de perras gordas o chicas de las anteriores de su mismo valor a las que vendrían a sustituir, monedas tanto de la República como de etapas anteriores que como hemos visto todavía estaban en circulación (Feria Pérez, 2002, 91).

Ante el excepcional hecho de encontrarnos ante un buen número de monedas, no podemos pasar por alto la razón por la cual han sido halladas en el contexto en el que nos encontramos, haciendo una pequeña reflexión, más allá de la perdida debida al evidente hacinamiento de personas, o por la oscuridad reinante en el interior del refugio. El hallazgo también de objetos de cierto valor como medallas, tal vez indicaría que la población al huir de sus casas en busca de cobijo, saldría con las pertenencias de valor guardadas en ellas, suponemos que por miedo a no encontrar sus hogares en píe tras los bombardeos. Tampoco podemos olvidar un hecho generalizado para todo momento de crisis como lo fue la Guerra Civil Española, el acaparamiento de moneda por parte de la población, y en consecuencia la falta de moneda fraccionaria, unido a la galopante inflación que sufrió la economía republicana durante los años de contienda. Este fenómeno ha sido ya motivo de interesantes y concluyentes estudios, tanto a nivel nacional como para la provincia de Alicante $^{3}$. Desde luego estos problemas no fueron ni mucho menos ajenos a la capital, recogiéndose en un buen número de artículos de opinión, notas de prensa e incluso viñetas donde se señalaba a los comerciantes como principales culpables de la falta de moneda. Así, en distintos artículos del diario comunista Nuestra Bandera, no solo se da cuenta del problema, sino que también se enumeran con toda clase de detalles las incautaciones

3. El tema es ampliamente estudiado por José Miguel Santacreu (1986). 

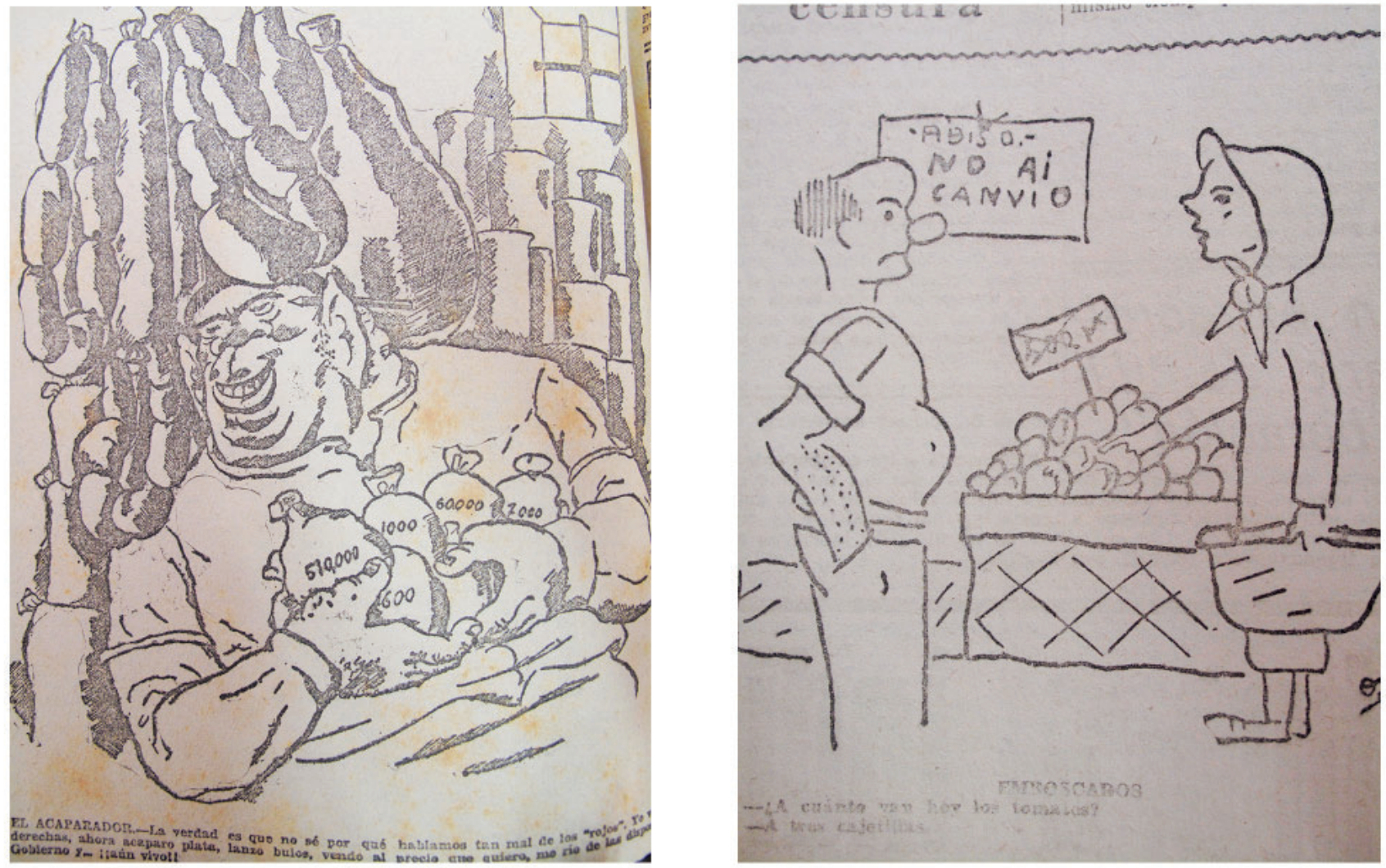

Figura 23: Viñetas alusivas a los acaparadores de moneda aparecidas en la prensa alicantina (AMA Nuestra Bandera 16 y 21-11-1937).

a comerciantes hechas por los inspectores de la Delegación de Hacienda, que podían ir desde las 3532 a las 121 pesetas. Estás quejas se acompañaban de viñetas alusivas, donde a los acaparadores se les llegaba a tildar incluso de quintacolumnistas, o lo que es lo mismo de traidores a la República (Fig. 23) (AMA, Nuestra Bandera 16-21-11 1937). Esta creciente falta de moneda fraccionaria por su atesoramiento, obligó a las autoridades Republicanas a la emisión en 1937 de las monedas de 25 y 50 céntimos, de las que contamos con tres ejemplos, así como a la emisión a nivel local, como sucede en innumerables pueblos y ciudades, de moneda en papel por parte del Consejo Municipal de Alicante. Este hecho queda recogido en una nota de prensa del Presidente del Consejo del 5 de julio de 1937 publicada también en Nuestra Bandera, donde se cita el acuerdo sobre la emisión de papel moneda en un taller local, pero con papel especial enviado desde Barcelona (AMA, Nuestra Bandera 8-6-1937). Hoy en día todavía se conservan alguno de estos billetes emitido por entonces. No parece extraño que fueran válidas para cualquier transacción, el uso de monedas sin marca alguna, o incluso monedas de procedencia extranjera, como la originaria de china con la que contamos, que por su peso y metal tuvieran un valor intrínseco. En cuanto al hallazgo de una moneda emitida por el bando nacional, en concreto la moneda de 25 céntimos de 1937, responde a un hecho constatado durante la contienda como es la convivencia entre las monedas republicanas y nacionales, a pesar de los decretos de prohibición de su uso por parte de ambos bandos, sufriendo devaluaciones o revalorizaciones conforme al discurrir de la guerra (Martorell Linares, 2006, 13). En este sentido, contamos también con una nota de prensa del Presidente del Consejo Municipal de Alicante, S. Martí del 20 de julio de 1937, donde se prohíbe el uso o la admisión de «otra moneda o representación de ella que la oficial» (AMA, Nuestra Bandera 31-6-1937). Bando municipal, que como vemos queda en papel mojado ante la propia realidad de la economía en estos difíciles tiempos de guerra en la ciudad de Alicante.

\subsubsection{La munición}

Íntimamente relacionado con el contexto en el que fue construido el refugio y de gran interés, son los restos de munición hallados sobre la superficie del interior. Así, se han recuperado un total de 14 vainas de casquillo, junto a tres proyectiles, algunos de los cuales describimos en el apartado correspondiente, y que en su mayoría pertenecen al calibre 7 × $57 \mathrm{~mm}$ (Figs. 24 y 25). Gracias también a encontrar casi íntegro el marcaje de sus vainas, podemos reconocer, en algunos casos, su año de fabricación y procedencia. Como vemos en las láminas, la procedencia para las vainas de fabricación española es la Fábrica Nacional de Toledo y la Pirotécnica Sevilla (Fig. 25, A, B, C, E, G, $\mathrm{H})$. Ambas fábricas, ya desaparecidas, desarrollaron 
proyectos conjuntos en artillería (Peris Sánchez, 1999, 62), dedicando también parte de su producción a la cartuchería para el popular rifle Mauser, cuyo calibre 7 x $57 \mathrm{~mm}$, es el más común entre las vainas recuperadas. No en vano es el propio rifle Mauser, en su versión española, el más usado durante la Guerra Civil por ambos bandos, puesto que además se trataba del rifle reglamentario del ejército al comenzar la guerra. En cuanto a los cartuchos importados, la procedencia es de lo más diversa, encontrando una vaina de procedencia austro-húngara de la Fábrica Manfred Weiss, una segunda de la Società Metallurgica Italiana, y una tercera de procedencia griega de la compañía Greek Powder and Cartrige (Fig. 25, F, D, I). La variedad, procedencia y antigüedad de los cartuchos, contrasta con los encontrados en las excavaciones realizadas metodológicamente en posiciones del bando nacional. Un ejemplo de este fenómeno, lo tenemos en los resultados de la exhaustiva excavación y estudio de la posición nacional del Castillo de Abánades, en el frente de Guadalajara. (González Ruibal, 2010, 34-36). Aquí se encontró un porcentaje del $58 \%$ y $24 \%$ de vainas de la Pirotécnica Sevilla y Fábrica Nacional de Toledo respectivamente, con una datación para todo el conjunto de los casquillos, indicada en los marcajes, de entre 1937 y 1938. Este dato contrastado es significativo, puesto que los ejemplares que tenemos en el refugio de la Plaza Séneca son por lo general de las primeras décadas del siglo XX, salvo una de las vainas datada en 1927. Así mismo, la variedad en su procedencia podría indicar que nos encontramos ante munición usada por el bando republicano que evidentemente usaba material mucho más obsoleto y heterogéneo que el obtenido por el bando nacional.

Con respecto a la munición importada, sabemos que tal y como ocurre en la actualidad, el comercio internacional de armamento estaba a la orden del día en los años de la Guerra civil, comprándose y revendiéndose material entre naciones sin limitación alguna en tiempos de paz, y con toda clase de argucias y triquiñuelas durante la guerra, de cara a sortear bloqueos o alianzas. Un ejemplo de este fenómeno lo tenemos en el casquillo encontrado de procedencia griega y perteneciente a la empresa Powder and Cartridge, propiedad del industrial e intermediario Pródromos Bodosakis-Athanasiadis. Éste traficante recibía en Grecia el armamento directamente de Alemania de la mano del mismísimo Hermann Goering, quien recibía su comisión, y que paradójicamente era el Comandante Supremo de parte de la aviación que bombardearía Alicante. Luego era revendido a la República haciendo el traslado en barcos mercantes con supuesto destino a Méjico. Uno de estos barcos, el alemán Bramhill llegó al mismo puerto de Alicante en octubre de 1936, procedente de Hamburgo y cargado, entre otro armamento, precisamente de 28 millones de cartuchos (Beevor, 1982, 488). Por otro lado, otro de los conocidos proveedores de munición de la República fue Rusia, que vendió o se deshizo de un ingente número de material de guerra obsoleto o en stock comprado anteriormente a otras naciones (González Ruibal, 2010, 123-143). Este puede que sea el origen de las otras dos vainas de bala importadas y encontradas en la superficie del refugio, es decir, las ya mencionadas de la

\begin{tabular}{|c|c|c|c|c|c|}
\hline Tipo & Calibre & Marcas & Origen & Año & $\mathrm{N}^{\circ}$ Inv. \\
\hline Vaina & $7 \times 57 \mathrm{~mm}$ & "P S 1914" & España, Pirotécnica Sevilla & 1914 & UE 9-5 \\
\hline Vaina & $7 \times 57 \mathrm{~mm}$ & "F N T 19..6" & España, Fabrica Nacional de Toledo & 1916 ó 1926 & UE 9-6 \\
\hline Vaina & $7 \times 57 \mathrm{~mm}$ & "P S 1927" & España, Pirotécnica Sevilla & 1927 & UE $136-3$ \\
\hline Vaina & $6,5 \times 52 \mathrm{~mm}$ & $" M \mid 93^{\prime \prime}$ & $\begin{array}{l}\text { Italia, Societa Metallúrgica Italiana, } \\
\text { Campo Tizzoro }\end{array}$ & 1930 & UE $137-2$ \\
\hline Vaina & No & "F N T 19..6" & España, Fábrica Nacional de Toledo & 1916 ó 1936 & UE $137-3$ \\
\hline Vaina & $8 \times 50 \mathrm{~mm}$ & "V 1916 W" & $\begin{array}{l}\text { Hungria, Manfred Weiss Patronenfabrick, } \\
\text { Budapest }\end{array}$ & 1916 & UE $138-3$ \\
\hline Vaina & $7 \times 57 \mathrm{~mm}$ & "P S $1 \ldots "$ & España, Pirotécnica Sevilla & No & UE $138-4$ \\
\hline Vaina & $7 \times 57 \mathrm{~mm}$ & "F N" & España, Fábrica Nacional de Toledo & No & UE 139-1 \\
\hline Vaina & $7 \times 57 \mathrm{~mm}$ & "E K" & $\begin{array}{l}\text { Grecia, Powder and Cartidge Co., } \\
\text { Atenas. }\end{array}$ & No & UE $140-6$ \\
\hline Proyectil & $7 \mathrm{~mm}$ & No & & No & UE 9-4 \\
\hline Proyectil & $7 \mathrm{~mm}$ & No & & No & UE $138-2$ \\
\hline Proyectil & $7 \mathrm{~mm}$ & No & & No & UE137-4 \\
\hline
\end{tabular}

Figura 24: Tabla de características de la munición hallada en interior del refugio Plaza Séneca. 


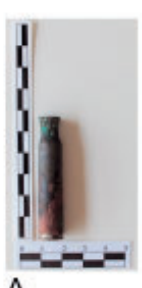

A

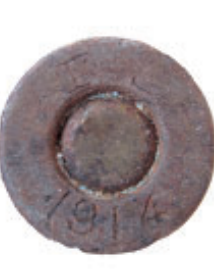

B
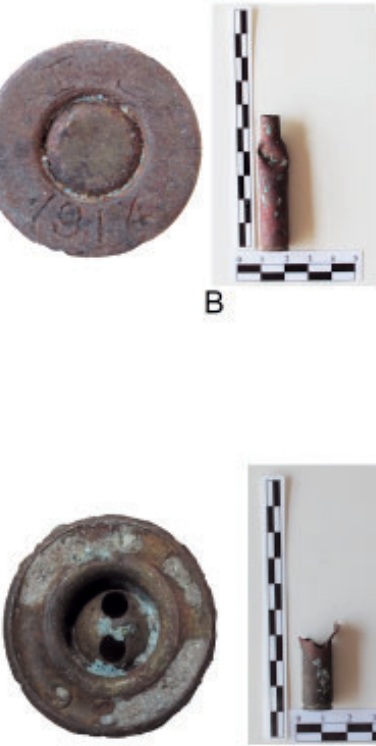

D
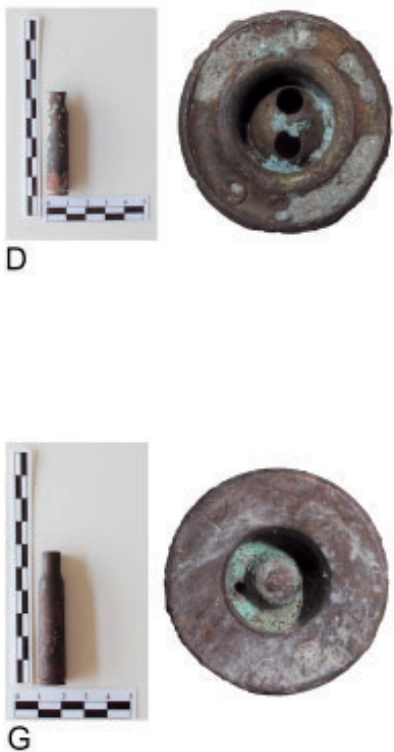

$$
\text { G }
$$

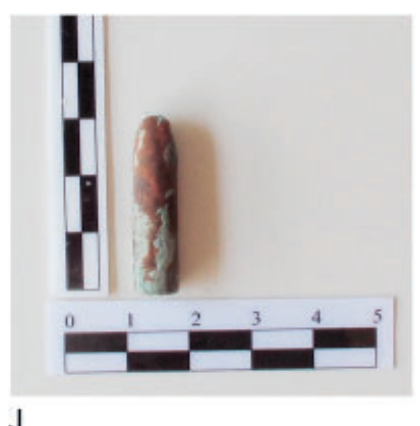

$J$

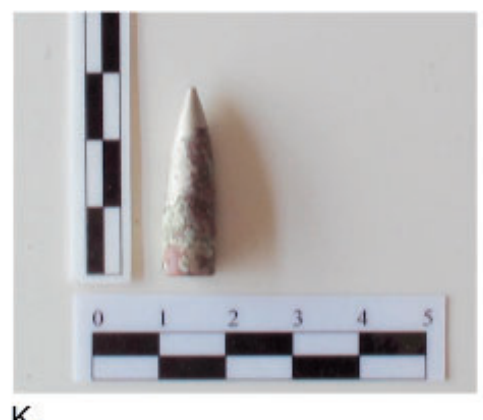

K

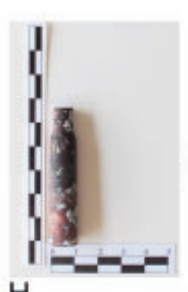

$\mathrm{H}$

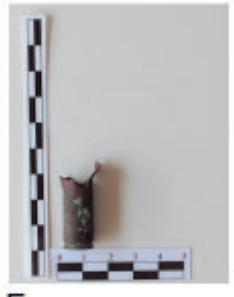

$\mathrm{E}$

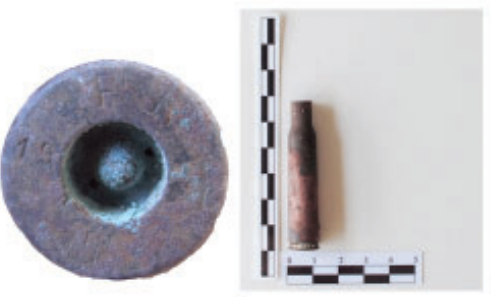

C
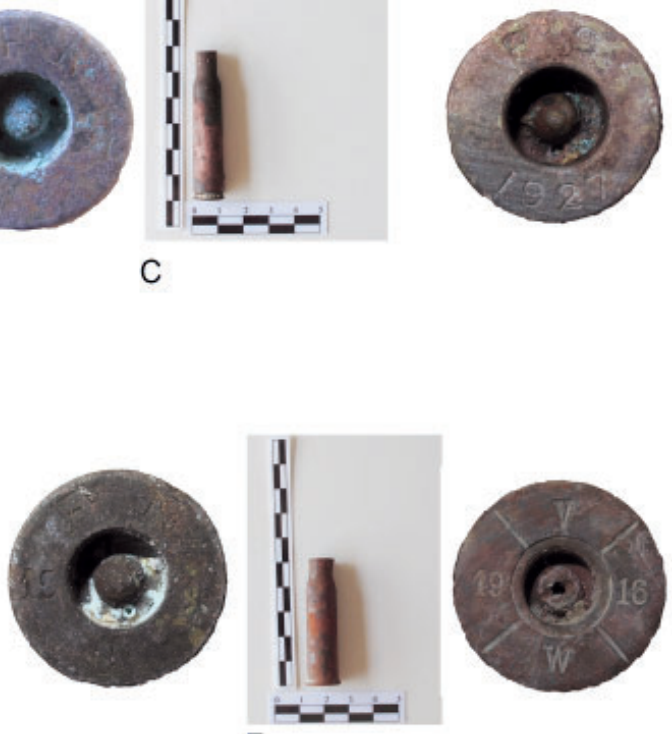

$\mathrm{F}$
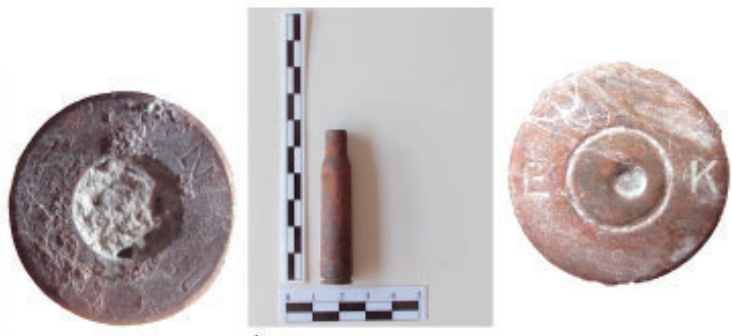

I

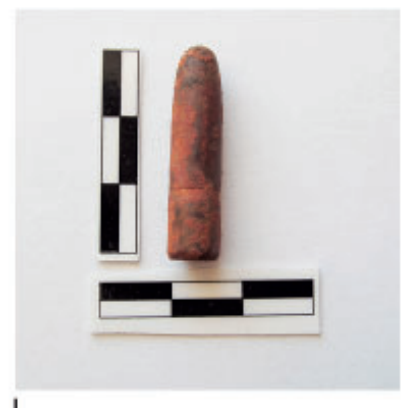

L

Figura 25: Munición hallada en interior del refugio. A. Vaina de Pirotécnica Sevilla 7 x $57 \mathrm{~mm}$. B. Vaina de la Fábrica Nacional de Toledo 7 × $57 \mathrm{~mm}$. C. Vaina de la Pirotécnica Sevilla. 7 x $57 \mathrm{~mm}$. D. Vaina de la Societa Metallúrgica Italiana 6'5 x $52 \mathrm{~mm}$. E. Vaina de la Fábrica Nacional de Toledo. F. Vaina de Manfred Weiss Patronenfabrick 8 x $50 \mathrm{~mm}$. G. Vaina de la Pirotécnica Sevilla. 7 x $57 \mathrm{~mm}$. H. Vaina de Fábrica Nacional de Toledo. 7 x 57 mm. I. Vaina de Greek Powder and Cartidge Co 7 x 57 mm. J. Proyectil de calibre: 7 mm. K. Proyectil de calibre: $7 \mathrm{~mm}$. L. Proyectil de calibre: $7 \mathrm{~mm}$.

italiana Società Metallurgica, y la Austro-húngara de 1916 de la fábrica Manfred Weiss.

Como conclusión, creemos que la presencia en el refugio de casquillos y balas, junto al hallazgo también de numerosa vajilla metálica, ollas y cazuelas de considerable tamaño, además de latas de conservas, puede que nos indique el uso del refugio por parte de algún contingente militar o milicia. Al hilo de esto, se habla de la presencia en la plaza de un cuartel de reclutamiento, aunque al respecto no tenemos fuentes documentales que lo confirmen. Sí que tenemos confirmada la ubicación, no lejos, del Cuartel del Batallón $\mathrm{N}^{\mathrm{o}} 6$ de Retaguardia, en el barrio de Benalúa, también una sede del Batallón de Obras y Fortificaciones, situado algo más cerca, en la calle Foglietti № 9 . Según consta en la documentación parece ser que es precisamente 
el Batallón de Retaguardia No 6 quien a requerimiento de la Junta de Defensa tendría el cometido de la vigilancia de los refugios (AMA Leg. 30/15). En este sentido, y también como hipótesis, no podemos olvidar que siendo Alicante la última ciudad en caer, recibió además de población civil refugiada, contingentes de tropa desplaza de los frentes y que hubo que acoger en la ciudad. Puede que el refugio se convirtiera así, y de manera puntual, en estos últimos momentos de la guerra, en albergue de dichas tropas.

\section{ELREFUGIO DE LA PLAZA DEL DR. BALMIS}

\subsection{REFERENCIAS DOCUMENTALES}

La primera cita que encontramos del refugio de Plaza del Dr. Balmis tiene fecha del 27 de enero de 1938, en las Actas de Sesiones de la Junta Local de Defensa Pasiva. En ella se dice que se encuentran bastante adelantadas las excavaciones en los refugios de la avenida de
Alfonso el Sabio, plaza del Dr. Balmis y paseo de Gadea, entre otros (AMA Arm. 19, Leg. 30/5). Por ello, pensamos que el inicio de la construcción del refugio, tuvo que tener lugar a finales de 1937, posiblemente en el mes de diciembre. Las obras habrían ya concluido en julio de 1938, momento en el que aparece el refugio de la Plaza Dr. Balmis ya construido, asignándosele el $n^{0} 65$ del plan general y con una capacidad de 250 personas (AMA A.19, Leg. 31/3) (Fig. 26, A).

En los partes de los bombardeos de 1939 se recogen los daños provocados a los edificios de la Plaza Balmis y cercanos (AMA, Arm. 19, Leg. 31/10 y 18). En ellos se hace referencia a desperfectos de poca importancia en los inmuebles $n^{\circ} 1,3$ y 6 de la plaza. Peor suerte corrieron las edificaciones situadas en la calle Cid, en los números 14 y 19, que sufrieron ruina completa. En esa misma calle, los números 15, 17, 18, 20 y 21 padecieron destrozos de menor cuantía y los números 23 y 26 desperfectos de menor importancia.

En septiembre de 1945 se redacta un proyecto de demolición de refugios situados en la vía pública

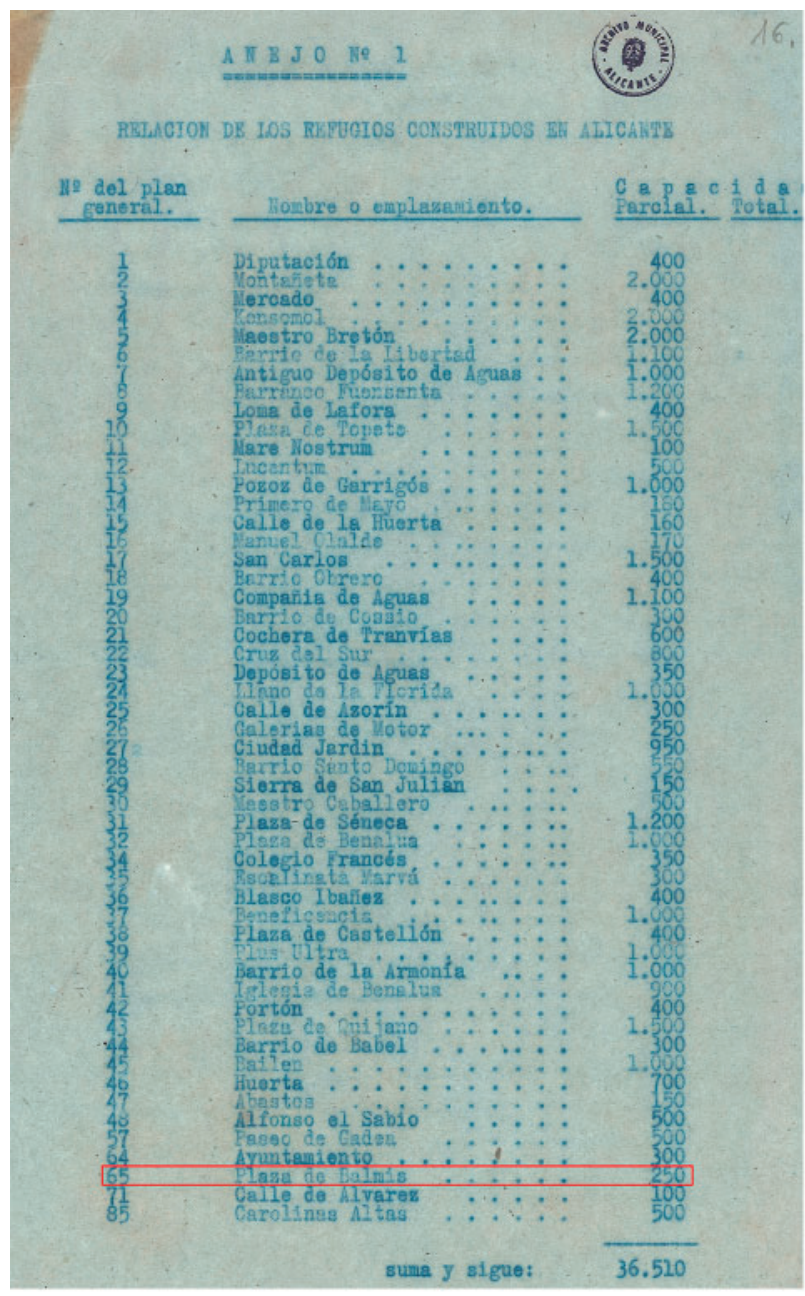

A

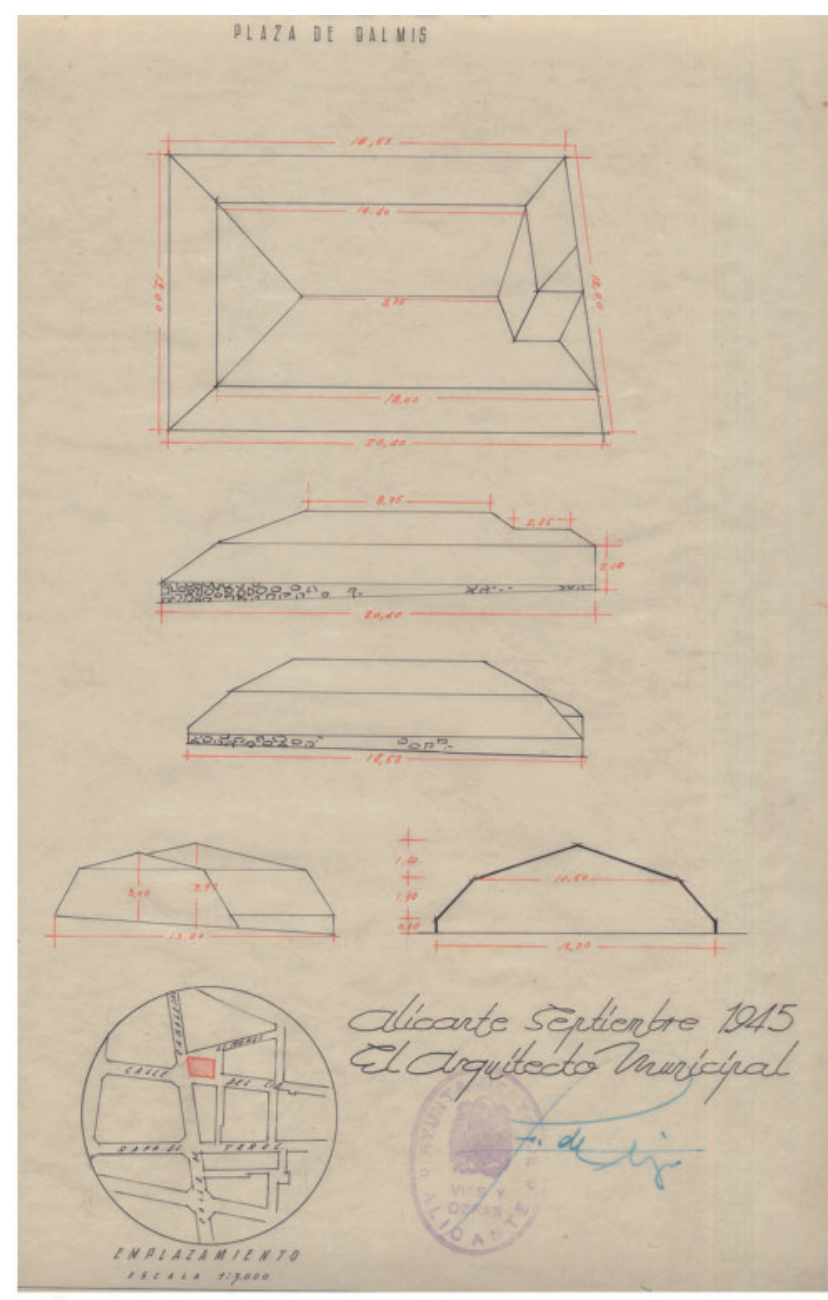

B

Figura 26: A. Listado de refugios construidos en julio de 1938. En él aparece ya el de la plaza Balmis con el no 65 del plan general de refugios y una capacidad de 250 personas (AMA, Arm. 19, Leg. 31/3). B. Plano de la cumbrera o cubierta del refugio de la plaza Dr. Balmis realizado en 1945 por el arquitecto municipal (AMA, Arm. 19, Leg. 30/15. Neg. de Fomento. Plano 446). 
(AMA, Arm. 19, Leg. 30/15), elaborado por el Arquitecto Municipal. La memoria de este proyecto afecta a la demolición de la cumbrera del refugio de la plaza del Dr. Balmis (entre otras). Las obras comprenden las siguientes operaciones:

- La demolición de toda construcción sobre la rasante de la calle o plaza.

- Transporte de todos los productos a un vertedero público, excepto los que se consideren aprovechables.

- Limpieza de toda clase de escombros acumulados en el interior de los refugios.

- Cerramiento de los accesos.

El presupuesto para la demolición de las cumbreras de plaza del Dr. Balmis y losa de hormigón de la avenida Gral. Marvá, frente a la plaza de Luceros, ascendía a 20.117,82 ptas. De esta forma el 8 de marzo de 1946 salen a licitación las obras de demolición. El 8 de mayo de este año resulta desierta la propuesta para la Plaza del Dr. Balmis. Las obras debieron licitarse por segunda vez ya que se conserva una petición de un particular (Manuel Pérez García) solicitando la compra de piedra caliza que se extrae del refugio de Plaza del Dr. Balmis, que está siendo derruido en ese momento. En fecha de 6 de agosto de 1946 este particular solicitaba varios metros cúbicos a un precio de 4,50 ptas. $\mathrm{m}^{3}$. El 19 de septiembre, el Ayuntamiento comunica, en virtud del decreto de 9 de septiembre, la adjudicación de la piedra resultante de la demolición de los refugios que existían en la Plaza del Dr. Balmis y en la Avda. Dr. Gadea a Francisco Forner Guijarro por el precio de 5 ptas. $\mathrm{m}^{3}$ (AMA, Arm. 19, Leg. 30/15). Esta petición indicaría que la cumbrera se estaba demoliendo en agosto y que en septiembre ya había sido demolida.

Los motivos por los que se decide demoler las cubiertas o cumbreras de los refugios fueron las quejas vecinales por el mal estado de las mismas, que se estaban desprendiendo, provocando la caída de cascotes en las vías públicas, así como el riesgo que corrían niños y adolescentes del vecindario al jugar en el interior de los refugios, además del vertido de escombros $\mathrm{y}$ basuras en su interior.

Posteriormente, en plena Guerra Fría, en el Plan fusionado de 1950 de la fase $6^{\circ}$ de refugios y $7^{\circ}$ de incendios, en la Ponencia de refugios del Ayuntamiento de Alicante, volvemos a encontrar una referencia al refugio de Plaza del Dr. Balmis. En ella aparece con el $\mathrm{n}^{\circ} 46$ y con una capacidad para 600 personas, con losa de hormigón y con las bocas de accesos tapiadas (AMA, Arm. 19, Leg. 30). Obviamente algunos de los datos que aporta son erróneos, pues la capacidad no era de 600 personas (cifra muy exagerada para las dimensiones del refugio), y el número que le asigna el plan general de 1938 es el 65. En 1950 los técnicos municipales no pueden acceder al interior del refugio ya que las bocas de acceso están cerradas por las obras de demolición recogidas en el proyecto municipal de 1945.

\subsection{INTERVENCIÓN Y CARACTERÍSTICAS DEL REFUGIO}

Se trata de un refugio público de tipo celular, que presenta planta rectangular y se corresponde al tipo 3, según indican, en la memoria anteriormente citada, el Arquitecto Municipal y el Ingeniero de Caminos de 9 de marzo de 1937 (AMA, Arm. 19, Leg. 30/2, Expediente sobre refugios antiaéreos). Se encuentra soterrado a una profundidad de $2 \mathrm{~m}$ bajo el nivel de la plaza (Fig. 27).

El refugio, de acuerdo con las recomendaciones y la normativa existente, presenta dos accesos localizados en extremos opuestos. En el lado noroeste, en la calle Canalejas, se encuentra el acceso 1, y en el sureste, en el ángulo formado por la unión de las calles Cid y Limones, el acceso 2. Estos presentan ingreso en codo doble con ángulos de $90^{\circ}$. El acceso 1 muestra un primer codo en forma de «L» al inicio y otro codo compuesto, en «U» al final del mismo. Del 2 sólo hemos podido documentar el codo compuesto localizado en los tramos finales de escalera. Con este trazado se pretendía amortiguar los efectos de las ondas expansivas de las explosiones, evitar la proyección de metralla, así como la caída de cascotes en el interior. Si uno de los accesos quedaba bloqueado por los escombros, siempre se podría usar el otro. Ambos tenían pasamanos de madera en los dos lados de los muros, que en la actualidad han desaparecido. Sólo se conservan restos de los soportes de hierro en los paramentos.

Los accesos están construidos sobre una base de hormigón en masa sobre la que se levantan los estribos y se construyen los tramos de escalera de ladrillo hueco, alternados por descansillos o rellanos. La normativa recomendaba no construir tramos de escalera de más de 14 peldaños indicando el porcentaje de la pendiente y las dimensiones de la huella y contrahuella de los escalones. Sobre los estribos se construyen las bóvedas de cañón con arcos rebajados. Estas están realizadas en ladrillo hueco de rasilla, dispuesto a panderete y enlucido con yeso. Presentan doble rosca de ladrillo alternada con una capa de cemento. Las bóvedas situadas sobre el principal tramo de escalera, presentan una inclinación de $38^{\circ}$ y $32^{\circ}$ respectivamente, encontrándose los muros enfoscados con cemento. El ancho de los pasillos es de $1,08 \mathrm{~m}$ y la altura oscila entre $1,81 \mathrm{~m}$ y $2,42 \mathrm{~m}$ (Figs. 30 y 31 ).

Los ingresos se encontraban colmatados por un relleno procedente de la cumbrera demolida, ya que parte del material resultante del derribo de la cubierta del refugio en 1946 fue utilizado para tapiar los accesos.

Las entradas estaban integradas en la cubierta o cumbrera. Este blindaje, que era la única parte del refugio en el exterior, por encima del nivel de la plaza, tenía la función de amortiguar o reducir los efectos de un impacto directo de las bombas. Si bien, el refugio ofrecía una buena protección contra cascotes, metra1la, ondas expansivas, impactos y explosiones en las inmediaciones, este era incapaz de soportar impactos directos de bombas de carga superior a los 150-250 


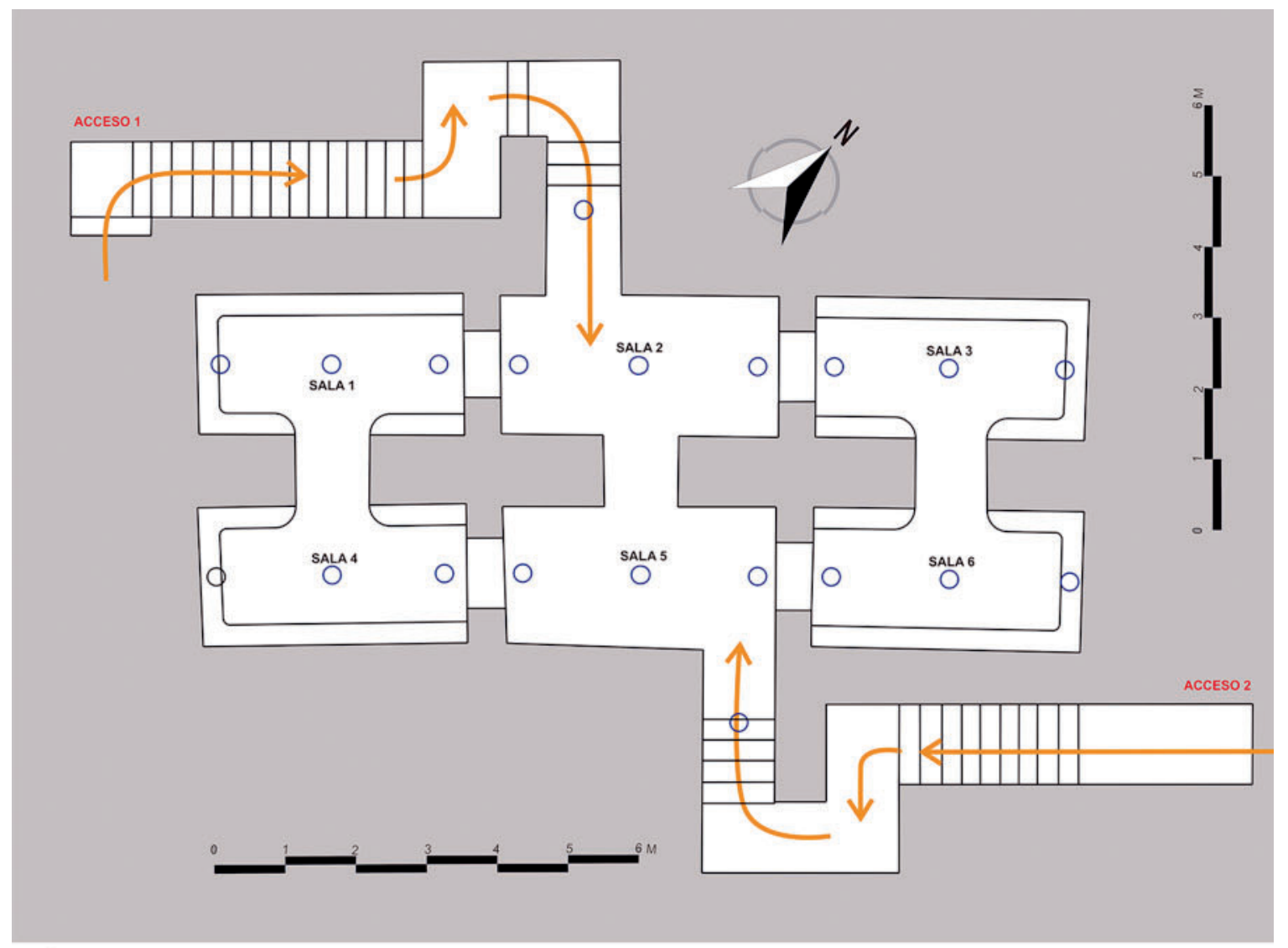

A

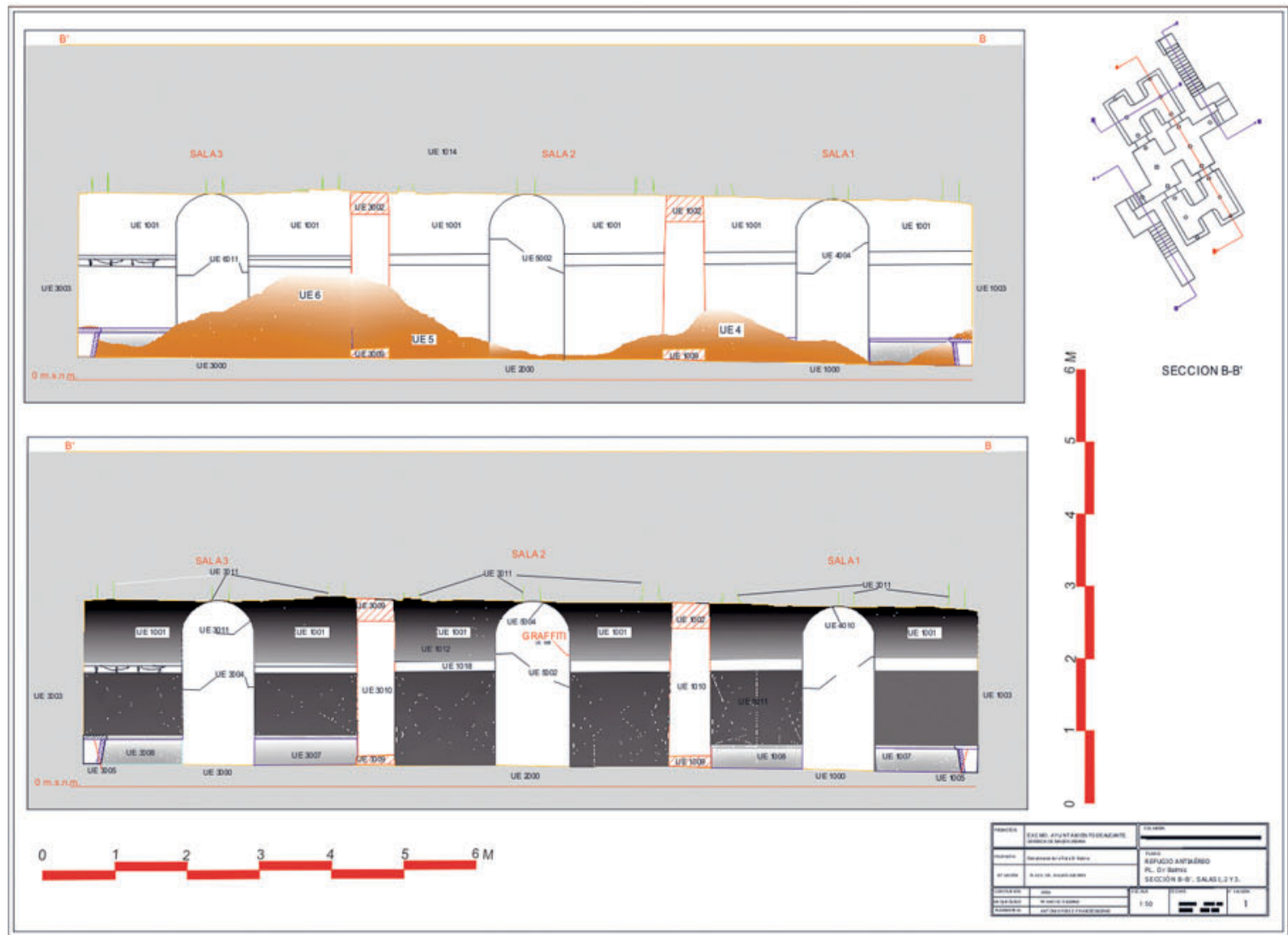

B

Figura 27: Planta y sección del refugio de la plaza Dr Balmis. (F. Lozano y A. Pérez). 


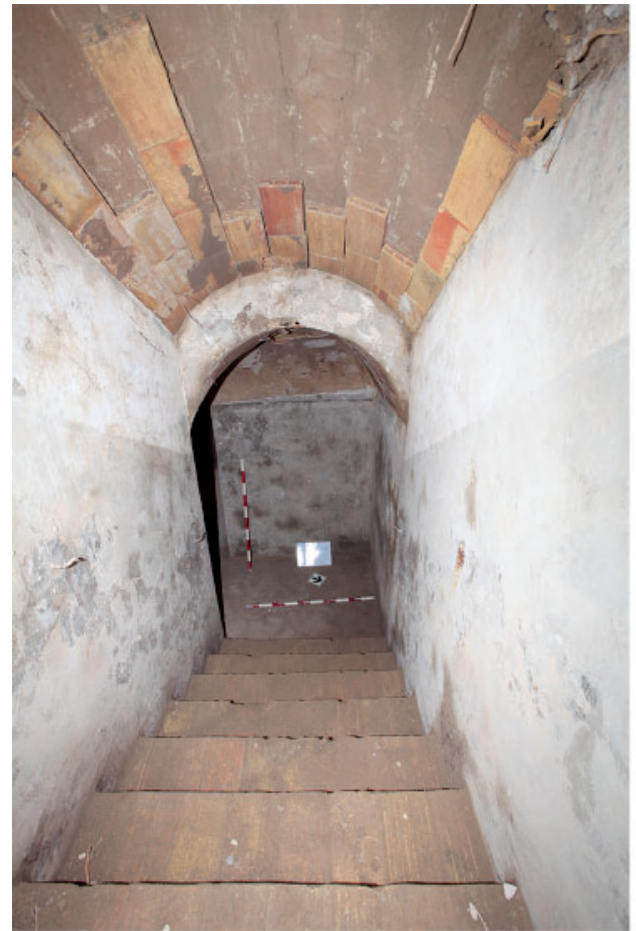

A

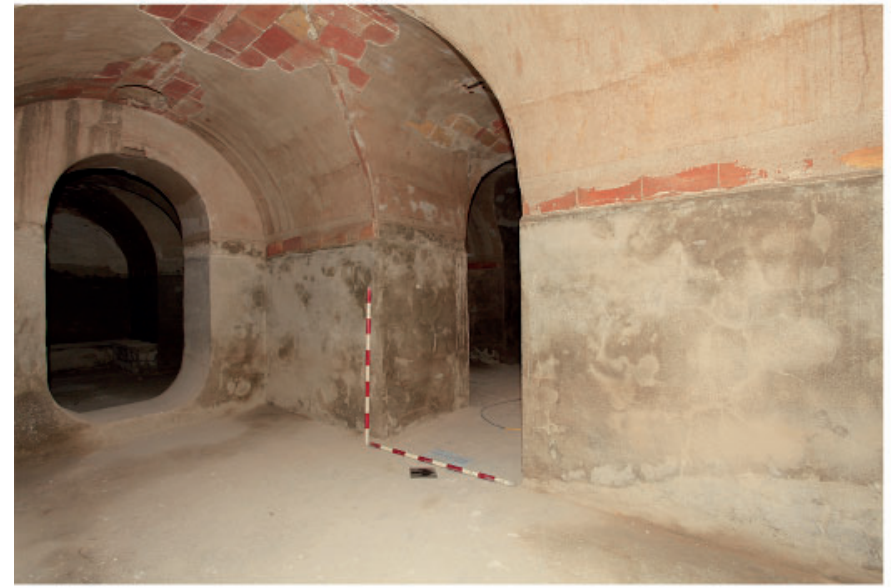

C

B
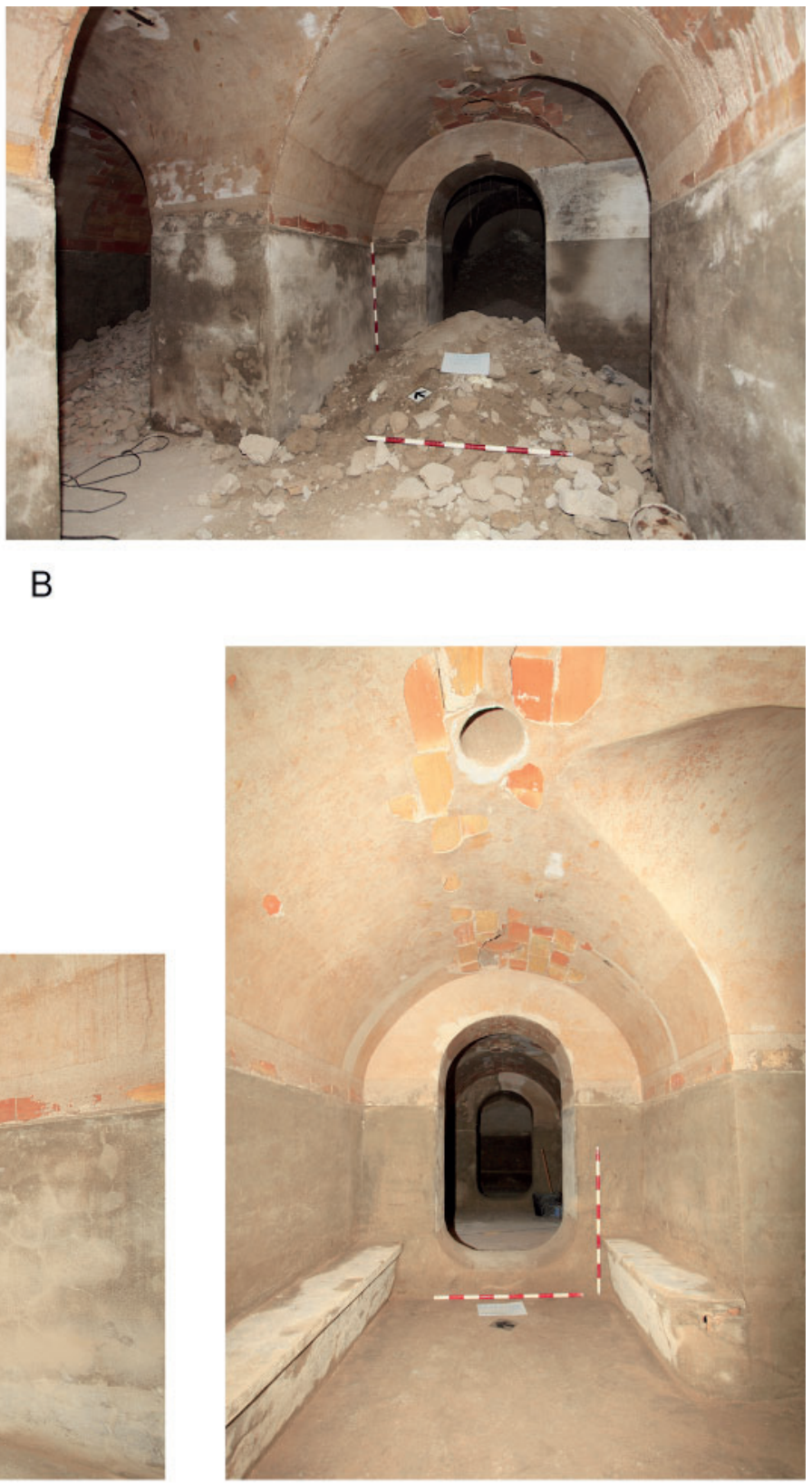

D

Figura 28: Interior del refugio de Balmis. A. Acceso 2. B. Celda 5 (estado previo). C. Celda 5 (estado final). D. Interior celda 1 (F. Lozano).

kg. Por ello se construyó una cubierta o cumbrera que posibilitaba una mayor protección. Se trataba de una construcción a dos aguas, con mampostería hormigonada. El núcleo podría estar realizado con varias capas de diferente grosor de mampostería hormigonada dispuestas horizontalmente y alternadas con capas de arena o tierra. En otros casos podía presentar un núcleo relleno de varias capas de tierra compactadas. Las paredes exteriores mostraban diversos grados de inclinación para posibilitar o favorecer el rebote de la munición. Esta cubierta presentaba planta cuadrangular irregular con una longitud de sus lados de 18,53 m (N), 13,00 m (E y O) y 20,40 m (S). Su sección es prismática con varios ángulos de inclinación (Fig. 26,
B). El tipo de blindaje exterior del refugio dependía de la localización topográfica del mismo, así como de los recursos disponibles. Si bien la cumbrera, como la de Balmis o similar, estaba muy extendida entre los refugios situados en plazas y solares, también se podía recurrir a otros sistemas, como verter tierra compactada (Iglesia de Santa María) sobre la parte exterior del refugio o disponer vías de ferrocarril y/o sacos terreros sobre la construcción (pozos de Garrigós, cochera de tranvías).

El conjunto presenta dos galerías paralelas con bóveda de cañón, separadas por un grueso muro con una longitud de $12,60 \mathrm{~m}, 0,99 \mathrm{~m}$ de anchura y una altura de $1,33 \mathrm{~m}$. Al igual que todas las estructuras del 


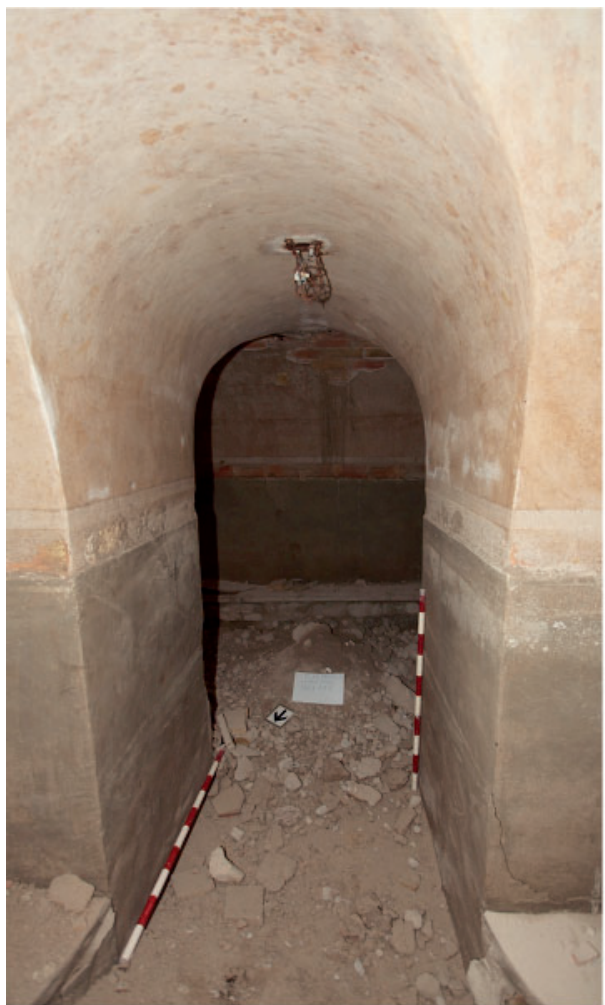

A

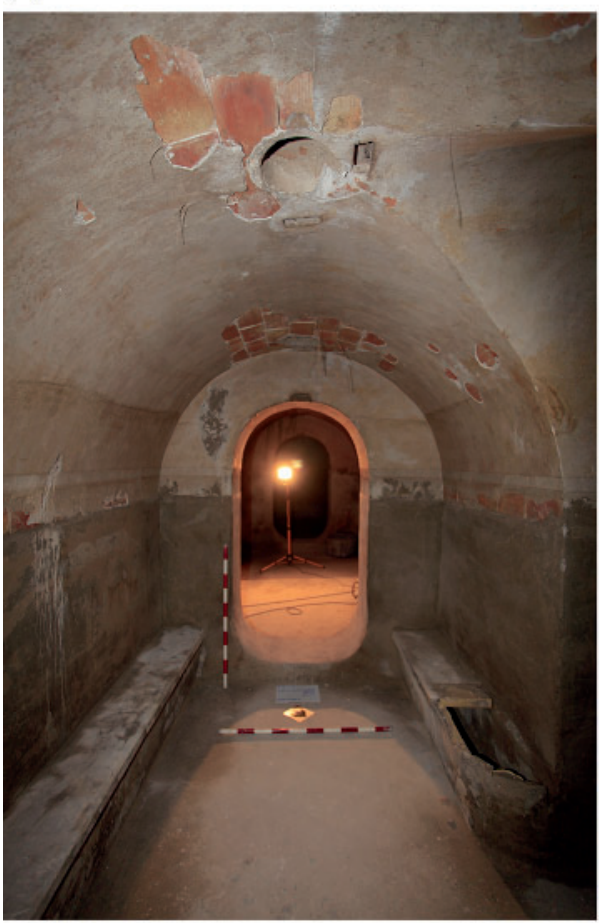

B

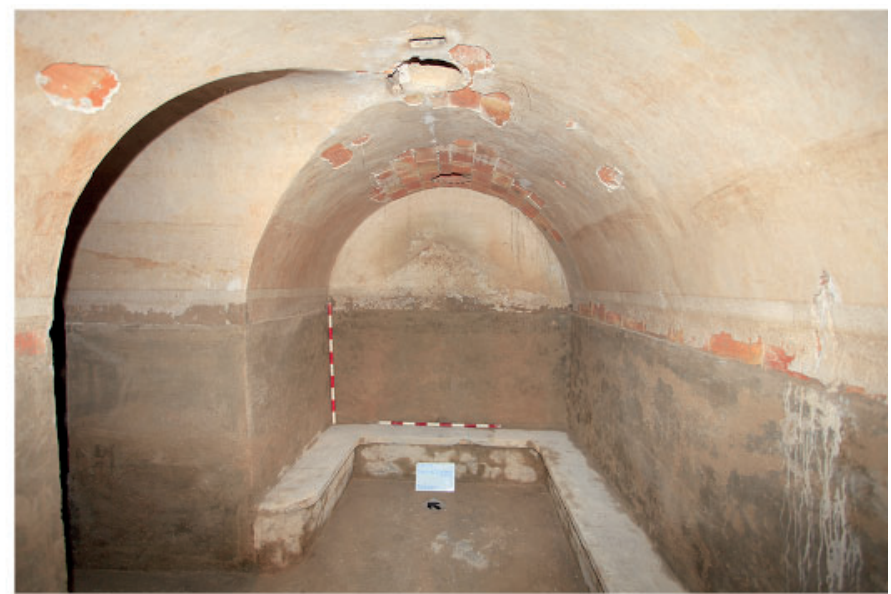

C

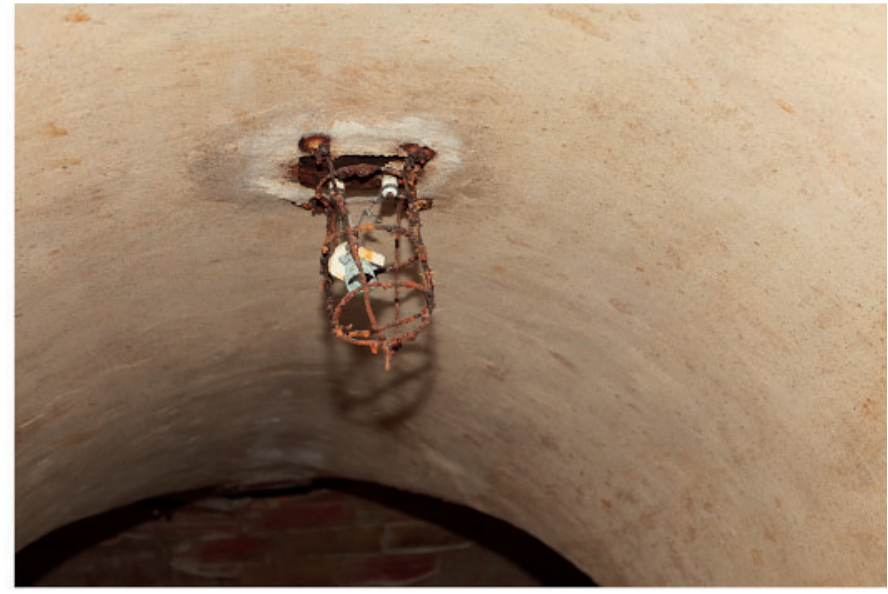

D

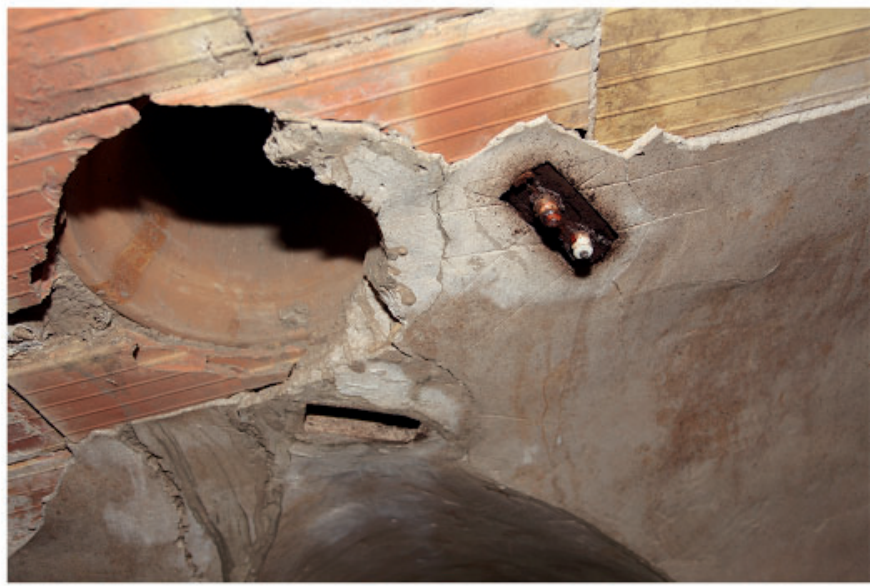

E

Figura 29: A. Vano entre salas 1 y 4. Conservaba in situ el sistema de iluminación. B. Celda 6. C. Interior celda 6. D. Detalle del sistema de iluminación. E. Celda 4. Detalle de uno de los 20 respiraderos e instalación eléctrica (F. Lozano).

refugio sobre las que se apoyan las bóvedas de ladrillo, está realizada en mampostería de medio tamaño trabada con cemento y dispuesta en opus incertum. Presenta una orientación noreste-suroeste y esta dotado con tres vanos con bóveda de arista que permiten el libre tránsito entre salas paralelas. En la parte superior de las bóvedas anteriormente citadas, se encontraban las lámparas que iluminaban las salas, conservándose sólo una in situ, la situada en el lado oeste. Se trata de una lámpara con rejilla protectora de hierro de forma 
troncocónica invertida con un apéndice en la parte inferior y 4 puntos de anclaje en la superior. El estribo o muro central soporta parte de las cargas de las bóvedas de ladrillo Los muros de mampostería muestran un enfoscado de cemento de grosor variable, mientras que la obra de ladrillo está enlucida por una delgada capa de yeso, cuyo grosor es también variable, de apenas milímetros.

La construcción se encuentra dividida o configurada en seis celdas de planta rectangular y unas dimensiones muy similares, con una longitud de 3,78 $\mathrm{m}$, una anchura de 1,98 y una altura máxima de 2,33 $\mathrm{m}$. Es de resaltar que sólo las celdas situadas a ambos lados de las cámaras centrales presentan bancos corridos realizados en obra de ladrillo y enlucidos con cemento.

Ambas galerías muestran bóveda de cañón con una luz de $1,98 \mathrm{~m}$ y una flecha de $0,99 \mathrm{~m}$. El intradós de las mismas está construido con fábrica de ladrillo hueco sencillo de rasilla, dispuestos a panderete y trabados con yeso, que resulta perfectamente visible en las juntas. Un refugio de similares características constructivas se encontraba en la plaza de Campoamor, aunque en la actualidad no existe, ya que fue demolido en 2007 durante la ejecución de las obras del Auditorio de Alicante (ADDA) de la Diputación Provincial de Alicante, siendo su demolición fotografiada y recogida en prensa escrita. En estas, son visibles las bóvedas de cañón realizadas en ladrillo hueco que se apoyan en estribos de mampostería trabados con cemento. Las bóvedas presentan doble rosca de ladrillo alternadas con capas de cemento. La capa de cemento exterior es más gruesa y muestra las varillas que formaba la armadura de hormigón. No sabemos si en nuestro caso la capa exterior de las bóvedas es de hormigón armado, pero pensamos que no debían ser muy diferentes. En el caso de Balmis, muy posiblemente, dispusiera de losa de hormigón bajo la cumbrera, al igual que en los casos del refugio de Alfonso El Sabio y el del depósito de máquinas de la estación de M.Z.A., muy similares al nuestro.

Las galerías presentan dos salas centrales completamente diáfanas, careciendo de cualquier elemento que estorbe o impida el movimiento. Estas cámaras presentan en ambos extremos otras dos salas, una a cada lado. Están diferenciadas o separadas por anillos de seguridad. Se trata de muros de $0,55 \mathrm{~m}$ de anchura realizados en mampostería trabada con cemento, dispuesta en opus incertum, enlucida con cemento hasta una altura de 1,33 $\mathrm{m}$ y por una delgada capa de yeso por encima de esa línea. Estos ejercerían una función de refuerzo de la estructura. Los anillos presentan unos característicos vanos de $0,48 \mathrm{~m}$ de anchura, 0,55 de grosor y 1,69 m de altura, con arcos de medio punto sobre los que se apoyan las bóvedas de las galerías. Estos vanos muestran un umbral sobreelevado, en relación al nivel del pavimento, de 0,14 m. Los ángulos inferiores del vano son cóncavos, confiriéndole cierto aspecto ovalado al conjunto. Sorprende la presencia de estos umbrales en una estructura como la de un refugio antiaéreo, puesto que al tratarse de un elemento de estas características, en un área de tránsito de personas, dificultaría el libre desplazamiento de las mismas, sobre todo en momentos de pánico, como los provocados por los bombardeos en que era fácil dejarse dominar por el miedo. El pavimento de toda la obra es de cemento sobre una base de hormigón en masa.

La construcción muestra un conjunto de 20 respiraderos realizados en cerámica, que se ubican en el eje central longitudinal de las bóvedas de las galerías principales, en el vértice de las mismas, separados $1,30 \mathrm{~m}$ aproximadamente. Se distribuyen tres por celda y uno en los pasillos de acceso a las cámaras 2 y 5 , entre las escaleras y las salas. Se trata de un conjunto de tuberías de cerámica ensambladas verticalmente, desde el vértice de la bóveda hasta la parte superior de la cumbrera, con una longitud máxima que podría situarse en torno a los 4 metros, conservándose parcialmente en la actualidad. Los tubos presentan un ensanchamiento en la base, en la zona de inserción, con un diámetro máximo de $29 \mathrm{~cm}$. La base del respiradero esta enlucida por una finísima capa de yeso que en algunos casos se ha perdido.

\subsubsection{Iluminación}

El tendido eléctrico se realizó por el exterior de los ladrillos, siendo visible en la parte superior de las bóvedas, los huecos de forma prismática rectangular de los apliques de madera, en los que se situaban las jícaras o aislantes eléctricos de porcelana por parejas. En la mayoría de los casos, estos apliques de madera han desaparecido por la humedad. Encontramos 29 de ellos en todo el refugio, siendo 5 para la instalación de las lámparas. Tres de ellas se encontraban en la parte superior de las bóvedas, en los vanos existentes en el grueso muro central. De esta forma una lámpara iluminaba dos salas. Las otras dos lámparas se encontraban en el pasillo interior de los accesos permitiendo la iluminación de los mismos. El cableado estaba formado por dos cables de tela trenzada paralelos que discurrían a la vista por la parte superior de las bóvedas. Los apliques de madera fueron enlucidos por una delgada capa de yeso. Las jícaras donde van enrollados los cables eléctricos son muy comunes en todos los refugios antiaéreos de este periodo y las encontramos en todos ellos, por parejas o en combinaciones mayores, tanto sobre apliques de madera como metálicos.

La obra, si bien se encuentra en unas condiciones de conservación optima, presenta un elevadísimo índice de humedad que provocó el desprendimiento de enlucidos y algunos ladrillos. Las paredes aparecen empapadas de agua y la cota del nivel freático debe encontrarse muy próxima.

El conjunto, excluyendo los accesos, presenta un total de $48,89 \mathrm{~m}^{2}$, que si lo multiplicamos por 4 personas por $\mathrm{m}^{2}$, siguiendo las recomendaciones del 


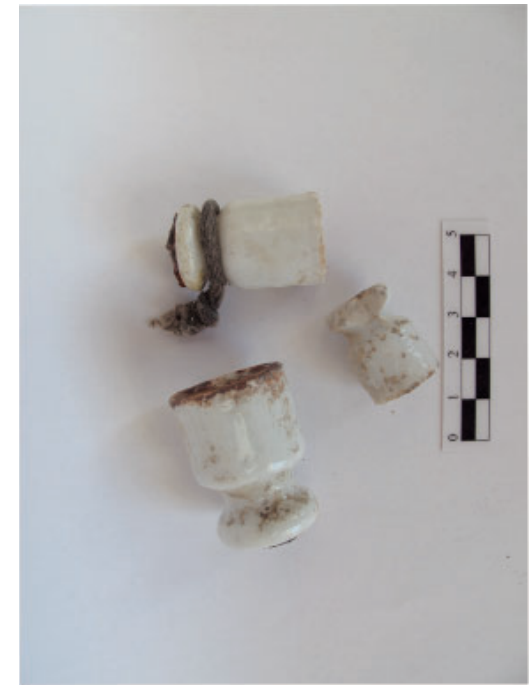

A

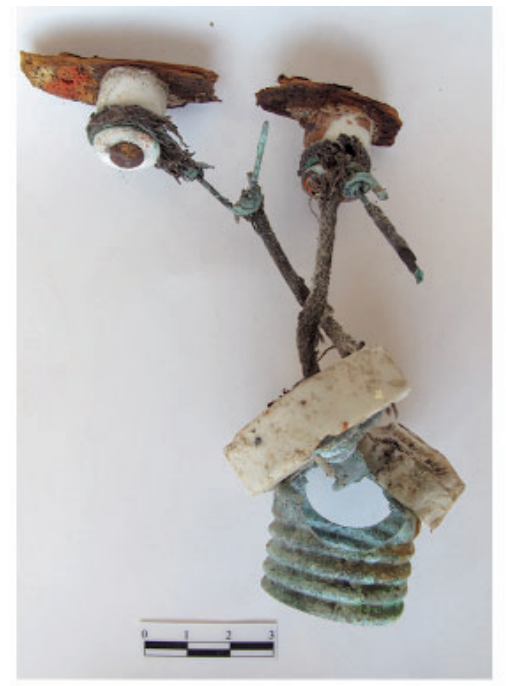

B

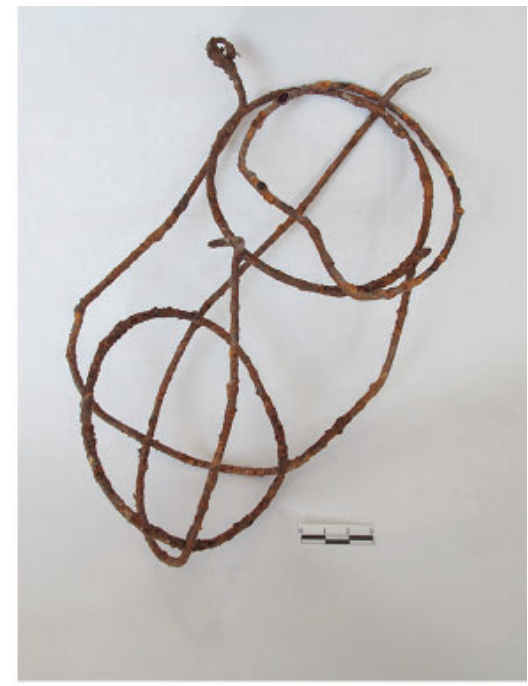

C

Figura 30: A. Jícaras de porcelana (PB'14/A-1/UE8-1). B. Restos de portalámparas (PB'14/S-1/UE4-6.) C. Rejilla protectora de lámparas (PB'14/A-2/UE2-6).

arquitecto municipal en el citado informe, nos arroja un total de casi 200 ocupantes, aunque esta cifra nos parece muy elevada. Consideramos más adecuadas 3 personas por $\mathrm{m}^{2}$, que nos arrojaría una cifra en torno a las 150 personas. La cifra aportada en 1950 (600 personas), la consideramos excesiva, muy exagerada y alejada de la capacidad real del refugio. Hemos de recordar que en 1950 el refugio está tapiado, ya que se bloquean las entradas en 1946 y no se tiene acceso a él.

\subsubsection{Grafitis}

En el interior del refugio hemos hallados 2 grafitis realizados con un lápiz de trazo grueso, en negro, sobre el enlucido de yeso en paredes y bóveda. El primero de ellos, esta elaborado con letra cursiva, redondeada, astiles alargados y ligeramente inclinada hacia la derecha. El trazo es llevado a cabo por dos sujetos y se encuentra en el lado oeste del vano que comunica las salas 2 y 5 . Se trata de un texto de contenido grosero con algunos trazos borrados. Su lectura es la siguiente:

«El que este (le)trero lee me la menee El que ha puesto la letra (...) Cabron el que es un cabronazo del

hijo (d)e otro maricon»

El segundo está ejecutado como en anterior. El trazo se lleva a cabo sobre el enlucido de yeso y es prácticamente ilegible. Solo se pueden apreciar los números 2253 y se encuentra en el acceso 2, próximo a la sala 5. Por las características y el contenido de los mismos, pensamos que fueron llevados a cabo por adolescentes.
La construcción de la edificación se realizó mediante la excavación a cielo abierto del solar hasta una profundidad de unos 5 metros. Posteriormente sobre una base de hormigón en masa se levantaron los estribos de mampostería hormigonada y los anillos de seguridad entre las celdas que soportarán las cargas de las bóvedas de cañón y reforzarán la estructura. A nivel de la plaza se elevará la cumbrera que posiblemente se apoye en una losa de hormigón. En el proyecto de refugio contra bombardeos del depósito de máquinas de la estación M.Z.A. de Alicante de 12 de febrero de 1939, podemos observar unas características muy similares al de Balmis, aunque en este caso los anillos de seguridad muestran arcos ojivales (AMA. Leg. $30 / 2$ ).

\subsubsection{Materiales arqueológicos}

Entre 1946 y 1992, debido a las obras realizadas en la plaza se vertió escombro por los diferentes respiraderos. Se trata de restos de obras y de ajuares muy fragmentados que debieron pertenecer a viviendas próximas. Las celdas que mayor volumen de escombros presentaban eran las situadas al este, siendo las salas centrales, las que mostraban un menor volumen de vertidos. Entre el material encontrado destacan los restos de rejillas, portalámparas, aislantes eléctricos de porcelana, que datamos en la primera mitad de 1938. Formando parte de los vertidos, hallamos fragmentos de un plato de porcelana con sello de fabricación en la base. Este fue fabricado en Santander por la fábrica Ibero Tanagra y su cronología puede situarse con posterioridad al primer cuarto del siglo XX. Con cronología similar tenemos un tapón de plomo con la palabra CEREGUMIL impresa en la parte superior. Obviamente se trataba del famoso reconstituyente cuya 
marca existe todavía. Otros materiales rescatados y datados en el último cuarto del siglo XX, son juguetes y jeringuillas de plástico (Fig. 30).

\section{LOS REFUGIOS Y LA LEGISLACIÓN DE PATRIMONIO}

La Ley 16/1985, de 25 de junio, de Patrimonio Histórico Español, en el art. 15, y la Ley 4/1998, de 11 de junio, de Patrimonio Histórico-Artístico Valenciano en su art. 58, consideran como zona arqueológica el lugar donde existen bienes muebles o inmuebles susceptibles de ser estudiados con metodología arqueológica. En los casos de las plazas de Séneca y del Dr. Balmis ha sido así, al igual que en otras intervenciones consideradas o denominadas como "Arqueología de la Guerra Civil». En este contexto y ya recogido en octubre de 2013 en el Plan Nacional de Arquitectura Defensiva en sus anexos 2 y 3 que hacen referencia al Decreto de Castillos de 22 de abril de 1949, y al texto de la Carta de Baños de la Encina aprobado el 30 de octubre de 2006, considera bienes patrimoniales que se deben conservar, restaurar y divulgar a toda fortificación o arquitectura de carácter militar, incluidas las edificadas en el siglo XX.

De igual forma, el Consell Valencià de Cultura redactó en 2004 un informe sobre la conservación del Patrimonio Histórico Militar de la Guerra Civil, y donde se alude repetidamente a la importancia de los numerosos refugios antiaéreos urbanos que se construyeron durante la guerra (Muñoz y Huguet, 2004). Este mismo órgano, en julio de 2007, redactó otro informe sobre refugios de la Guerra Civil, con mención particular a los de la ciudad de Valencia, en el que se establece la necesidad de que se tomen, en la medida de lo posible, las decisiones oportunas para la conservación de los refugios antiaéreos urbanos en toda la Comunidad Valenciana (Muñoz y Huguet, 2007).Por otra parte, los refugios antiaéreos situados en el subsuelo de la plaza de Séneca y Plaza del Dr. Balmis están incluidos en el Plan Especial de Protección Arqueológica (P.E.P.A.) del Ayuntamiento de Alicante, donde se le asignan el no 31 y código 280 al de la Plaza de Séneca, mientras que al de la Plaza de Dr. Balmis se le asigna el $\mathrm{n}^{\circ} 46$, código 295. A pesar del tiempo transcurrido desde su redacción, este plan de protección se encuentra a día de hoy sin aprobar.

\section{CONCLUSIONES}

El conflicto civil que sufrió España tras el fracaso del golpe militar del 17 de julio de 1936 supuso uno de los mayores traumas de la historia reciente de este país. Durante la contienda por primera vez se llevaron a cabo intensos bombardeos de área sobre núcleos urbanos de forma sistemática e indiscriminada, por lo que las juntas locales de defensa pasiva se vieron obligadas a poner todos los recursos y medios a su alcance para intentar evitar una tragedia humanitaria mayor. Como hemos visto, en Alicante se materializó un vasto programa de construcción de refugios antiaéreos sin precedentes (Fig. 31), sacando el máximo provecho de unos recursos muy limitados para una pequeña ciudad asediada como lo fue Alicante, provecho que tal vez no hubiera sido posible sin la colaboración de todas las instituciones y de gran parte de sus ciudadanos. Los refugios de las plazas de Séneca y Dr. Balmis forman parte sin duda de este admirable esfuerzo.

La localización y la condición de refugios públicos de ambas construcciones les confiere algunas similitudes, a pesar de su diferente tipología, dimensiones y cronología. Una de ellas es la excavación del solar a cielo abierto y a escasa profundidad, evitando así los problemas de filtraciones de agua. Recordemos en este sentido la cercanía a la costa o puerto de los dos emplazamientos. También como elementos comunes, encontramos dos accesos en codo, fuerte losa de hormigón y blindaje exterior, dotándoseles de bancos, respiraderos e instalación eléctrica. En cuanto a dimensiones y capacidad, hay sobradas diferencias, mientras que el refugio de la Plaza de Séneca cuenta con un espacio disponible de $214 \mathrm{~m}^{2}$ y una capacidad alrededor de las 1000 personas; el refugio de la Plaza del Dr. Balmis contaría con un espacio de $48,89 \mathrm{~m}^{2}$, y aforo de unas 200 personas. Hallamos también claras diferencias morfológicas y estructurales, presentando el refugio de Séneca una planta rectangular con dintel de hormigón armado, dotada de un corredor central al que se abren las distintas celdas o cubículos. En Balmis, sin embargo, encontramos 2 galerías abovedadas paralelas, configuradas en 6 cámaras o salas. Puestos a comparar nuestros refugios con otros documentados en la ciudad de Alicante, vemos como a pesar de las semejanzas estructurales, salvo los casos ya citados, no hay un paralelismo exacto entre ellos, puesto que claramente adaptan su morfología a las características del terreno, disponibilidad de materiales y aforo. Este fenómeno podemos también comprobarlo si intentamos paralelizarlos con otros refugios antiaéreos de fuera de nuestra ciudad, ya sea en localidades como Alcoy, Albacete, Almería. o Valencia, donde desde luego sí que existen semejanzas o elementos comunes, ya sean elementos estructurales, materiales, mobiliario, señalética o los elementos impuestos por las normativa vigente. Enumerar estas semejanzas y diferencias entre tantos refugios, (recordemos que son en torno a los 90 en la ciudad de Alicante), aunque muy interesante, requeriría de un artículo o monográfico mucho más extenso, de lo que permiten estas líneas. Y que esperemos se lleve a cabo.

Por otra parte, y como se ha mencionado en el artículo, y gracias a la numerosa documentación conservada en el Archivo Municipal de Alicante, podemos deducir que la fecha de finalización para el refugio de la Plaza de Séneca estaría en torno a los meses de agosto a septiembre de 1937. Por otro lado, sabemos 


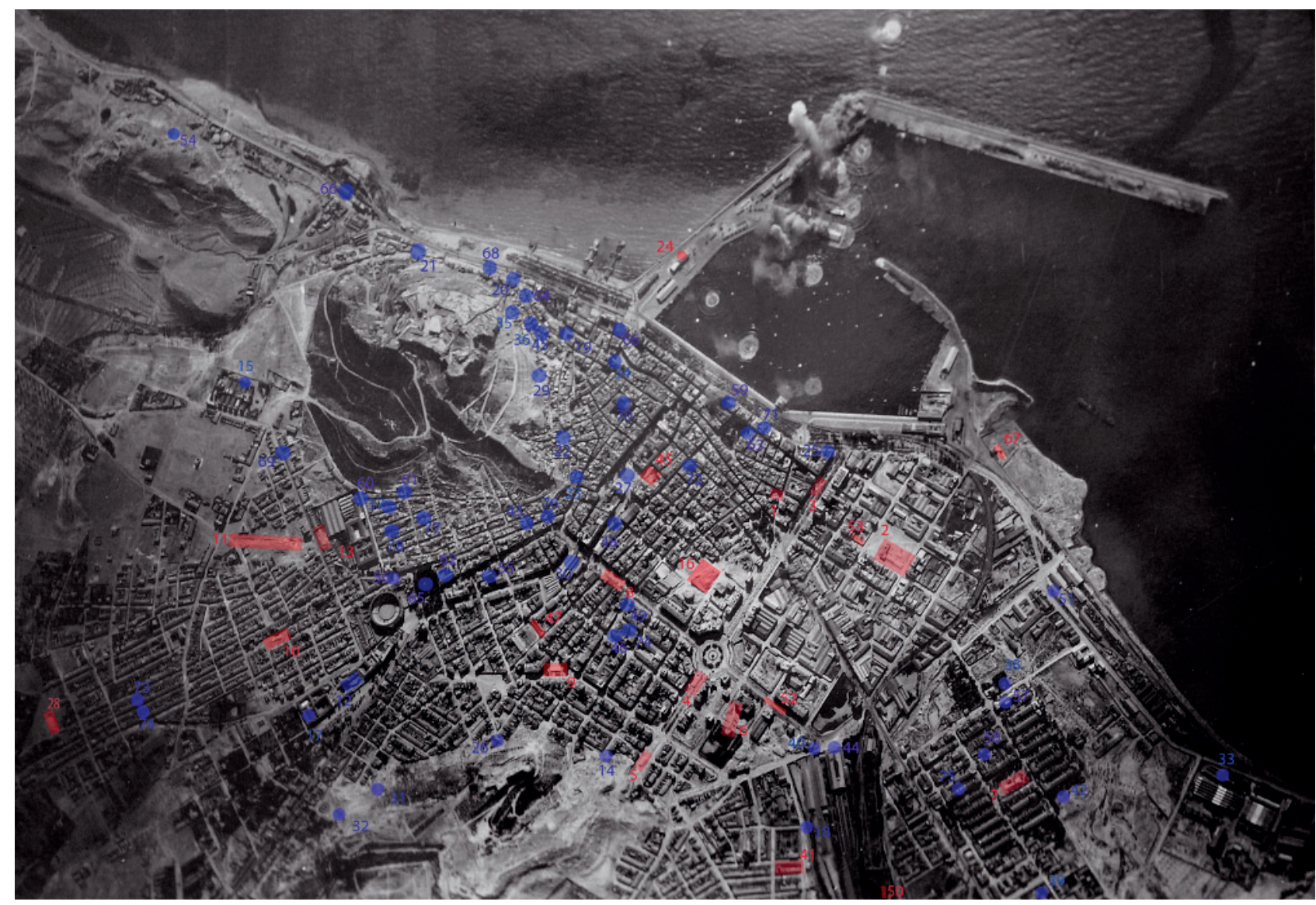

Figura 31: Localización de los refugios en fotografía aérea italiana de 1938. 1 Balmis. 2 Séneca. 3 Dr. Gadea. 4 Gral. Marvá. 5 Escalinata Gral. Marvá 6 Diputación de Alicante. 7 Pl. Navarro Rodrigo. 8 Av. Alfonso X El Sabio. 9 Pl. Hermanos Pascual. 10 Pl. Castellón. 11 C. San Carlos/Av. En proyecto. 12 P. De Campoamor. 13 Fábrica de tabaco. 14 Maestro Bretón. 15 Hospital Provincial. 16 Pl. de la Montañeta. 17 Beneficencia. 18 Bono Guarner/Estación MZA. 19 P. de Sta. María. 20 Tunel Sta. Barbara. 21 Pl. de Topete. 22 P. De Quijano. 23 C. Primero de Mayo. 24 Antigua Comandancia de Marina. 25 Sede universitaria. 26 Cast. S. Fernando. 27 Rambla/Banco de España. 28 Pl. del Sol. 29 Pozos de Garrigós. 30 Mercado Central de Abastos. 31. Maestro Caballero. 32 General Prim. 33 Fábrica de sacos. 34 Ayuntamiento. 35 C. Mare Nostrum. 36 C. Lucentum. 37 C. Manuel Olalde. 38 Aguas de Alicante. 39 Reformatorio de adultos. 40 Av. Salamanca. 41 C. Santaolalla /Carlota Pasarán. 42 Iglesia de Benalua. 43 C. Ingeniero F. Mira. 44 Estación MZA. 45 C. Bailen/conv. Capuchinas. 46 Diario Nuestra Bandera/C. Quintana. 47 Lonja de verduras. 48 Casa de Socorro. 49 C. Pablo Iglesias. 50 Deposito MZA. 51 Estación de Los Andaluces. 52 Av. de la Estación. 53 C. Portugal. 54 Sierra S. Julián. 55 Escuela modelo. 56 C. Sevilla. 57 Colegio Benalua. 58 Dr. Just. 59 Casino. 60 C. de la Huerta/Cuesta Fábrica. 61 C. Huerta/Paraíso. 62 C. S. Vicente. 63 Telégrafos. 64 C. Villavieja. 65 Plaza de España. 66 Hotel Palas. 66 Estación de la Marina. 67 Heliodoro Madroña. 68 Patrimonio artístico. 69 C. S. Carlos. 70 Concatedral S. Nicolas. 71 C. García Hernández. 72 Banco Vizcaya. 73 Dr Buades I. 74 Dr. Buades II. Berenguer de Marquina. 75 C. Pérez Medina. 76 C. Concepción. 77 C. Nueva Baja I. 78 C. Nueva Baja II. 79 C. de la Huerta. 80 Delegación Gobierno. 81 Hacienda (USAMI/ F. Lozano).

que la edificación del refugio de Dr, Balmis tendría lugar durante la primera mitad de 1938. Vemos también por grafitis y documentos, la presencia que tuvieron los sindicatos tanto en la construcción como en su mantenimiento. En cuanto al material arqueológico, destacaremos la presencia de un conjunto de monedas y munición que nos han aportado una inestimable información y que son claras evidencias del trasiego constante de una atemorizada población que pudo salvar sus vidas gracias a la presencia de estas magníficas construcciones.

Las intervenciones desarrolladas en ambas plazas, han supuesto un paso más en el conocimiento de un patrimonio que la desidia, tal vez por el dolor producido, había relegado al olvido. Hemos sido testigos en los últimos años de numerosos proyectos de recuperación e investigación, que unidas a distintas iniciativas ciudadanas, están enfocadas a la recuperación y conservación del rico legado vinculado a la Guerra Civil Española. El paso del tiempo parece haber servido para contemplar con otra perspectiva, alejada de viejos prejuicios, todo este inestimable patrimonio. La puesta en valor de esta herencia esperamos que sirva no solo para recuperar estos valiosos espacios defensivos, sino también para recordar unos dramáticos hechos de nuestra historia reciente que nunca debieron ocurrir, y que no podemos permitir que se repitan. En este sentido esperamos que la reciente apertura del Centro de Interpretación de los Refugios Antiaéreos de Alicante, junto a la adecuación para la visita de los refugios de 
Plaza de Séneca y de Plaza de Dr. Balmis sirva para tal cometido ${ }^{4}$.

\section{ANEXO. CATÁlOGO DE MONEDAS DEL RE- FUGIO DE LA PLAZA DE SÉNECA}

1- GOBIERNO PROVISIONAL. 5 céntimos. Barcelona 1870

A.-

R.- DO [scientas piezas ]AS [en kil ] OG [CI) N [CO CENTIMOS ] OM. León rampante con cabeza vuelta sobre escudo de España

Metal: cobre.

4'2 gr.; 25 mm.; No pc

Calicó et alii, 1994: Gobierno provisional, p. 649, tipo $9, \mathrm{n}^{\circ} 21$

Inv.:137-1

Bibl.: Inédita

Yac: Refugio Plaza Séneca, Alicante.

Observ.: Letras y dibujo en anverso perdidos, apenas se distingue marca de valor y sí OM marca de acuñación.

2- ALFONSO XII 5 céntimos. Barcelona $1877,1878,1879$

A.-ALFONSO XII POR LA GRACIA DE [dios ]. Cabeza del rey a la derecha.

R.- Escudo de la corona.

Metal: cobre.

4'3 gr.; 25 mm.; 6 pc

Calicó et alii, 1994: P. 670, tipo 15, nº 58, 59, 601877 , 1878,1879

Inv.:139-2

Bibl.: Inédita

Yac.: Refugio Plaza Séneca, Alicante.

Observ.: Letras en reverso perdidas. No aparece año ni marca de valor.

3- ALFONSO XII 10 céntimos. Barcelona 1878,

A.- ALFONSO XII POR LA GRACIA DE DIOS. Cabeza del rey a la derecha.

R.-

Metal: Cobre.

8'6 gr.; 30 mm.; 6 pc

Calicó et alii, 1994: Alfonso XII, p. 670, tipo 14, no $55,56,57$

Inv.:136-1

Bibl.: Inédita

Yac: Refugio Plaza Séneca, Alicante.

Observ.: Letras y dibujo en reverso perdidas. No aparece año ni marca de valor.

4. Queremos mostrar nuestro agradecimiento a Javier Giménez, a Inmaculada Garrigós y a Carolina Fuentes por su inestimable ayuda.
4- SEGUNDA REPÚBLICA. 1 peseta. MADRID. 1937

A.- REPVBLICA ESPAÑOLA. Cabeza femenina a la izquierda.

R.- 1 PESETA, [1937]. Vid.

Metal: Latón.

4'6 gr; 23 mm.; 6 pc

Calicó, 2008: Segunda República, tipo 2, no 2

Inv.: PS'138-1

Bibl.: Inédita

Yac.: Yac.: Refugio Plaza Séneca, Alicante

Observ.: según Calicó (2008, 848 y Calicó et alii, 1994), estas piezas se acuñaron en la Fábrica de la Moneda de Castellón con el material necesario llevado desde Madrid.

5- SEGUNDA REPÚBLICA. 1 peseta. MADRID. 1937

A.- [república] ESPAÑOLA.Alegoría de la república con Cabeza a la izquierda.

R.- 1 PESETA, [1937]. Vid.

Metal: Latón.

4'5 gr; 23 mm.; 6 pc

Calicó, 2008: Segunda República, tipo 2, nº 2

Inv.: PS'144-1

Bibl.: Inédita

Yac.: Refugio Plaza Séneca, Alicante.

Observ.: según Calicó (2008, 848 y Calicó et alii, 1994), estas piezas se acuñaron en la Fábrica de la Moneda de Castellón con el material necesario llevado desde Madrid.

6- SEGUNDA REPÚBLICA. 50 céntimos. MADRID. 1937

A.- REPVBLICA ESPAÑOLA, 1937. Alegoría de la República sentada a la izquierda con rama de olivo en el brazo derecho.

R.- 50 CÉNTIMOS. Con orla de puntos.

Metal: cobre.

5'6 gr.; 23 mm.; 6 pc

Calicó, 2008: Segunda República, p. 848, tipo 3, nº 3,5

Inv.:139-1

Bibl.: Inédita

Yac.: Refugio Plaza Séneca, Alicante.

Observ.: Estas monedas fueron acuñadas en Castellón, pero con los troqueles y material de la Casa de la Moneda de Madrid, de ahí su procedencia en la bibliografía (Calicó et alii, 1994; Calicó, 2008).

7- SEGUNDA REPÚBLICA. 50 céntimos. MADRID. 1937

A.- REPVBLICA ESPAÑOLA, 1937. Alegoría de la República sentada a la izquierda con rama de olivo en el brazo derecho.

R.- 50 CÉNTIMOS. Con orla de puntos.

Metal: cobre.

5'6 gr.; 22 mm.; 6 pc

Calicó, 2008: Segunda República, p. 848, tipo 3, no 3 y 5 
Inv.:136-2

Bibl.: Inédita

Yac.: Refugio Plaza Séneca, Alicante.

Observ: Estas monedas fueron acuñadas en Castellón, pero con los troqueles de la Casa de la Moneda de Madrid, de ahí su procedencia en la bibliografía (Calicó et alii,1994; Calicó, 2008).

8- SEGUNDA REPUBLICA. 25 Céntimos. Madrid 1938

A.- REPÚBLICA ESPAÑOLA - 1938 libro de ciencia rompiendo cadenas cruzadas.

R.- 25 CTS. Espigas de trigo.

Metal: Cobre.

4'3 gr.; $21 \mathrm{~mm}$; /:3 pc.

Calicó et alii, 1994: Segunda República, p. 690, tipo $9, \mathrm{n}^{\mathrm{o}} 12$

Inv.: PS'13 9-2

Bibl.: Inédita

Yac.: Refugio Plaza Séneca, Alicante UE 9-1

Observ.: Estas monedas fueron acuñadas en Aspe y Castellón, pero con los troqueles de la Casa de la Moneda de Madrid, de ahí su procedencia en la bibliografía.

9- GUERRA CIVIL. 25 Céntimos. VIENA. 1937

A.- ESPAÑA- UNA GRANDE LIBRE 1937 II AÑO TRIVNFAL. Yugo y flechas.

R.- 25 CTS. Escudo de armas de los Reyes Católicos y rama de olivo.

Metal: Cupro-níquel.

6'7 gr.; 25 mm.; 6:pc

Calicó et alii, 1994: Gobierno de Burgos, p. 693, tipo

$1, \mathrm{n}^{\mathrm{o}} 1$

Inv.: PS'13 9-1

Bibl.: Inédita

Yac.: Refugio Plaza Séneca, Alicante UE 9-1

Observ.: Moneda realizada en Austria por no encontrarse taller alguno en el territorio del bando nacional.

10- MONEDA CASH CHINO. Pekín

A.- 通寶: Ideograma chino con la palabra dinero.

R.- Ideograma chino de la ceca en manchú.

Metal: Cobre.

3'1 gr.;23 mm.; /:No pc

En Catálogo Krause, 2012, p. 239 y 241

Inv.: PS'13 122-1

Bibl.: Inédita

Yac: Refugio Plaza Séneca, Alicante

Observ.: Moneda con orificio central de una de las cecas de Pekín. Ceca de Boo-Yuwan. En el anverso no se reconoce el nombre y era del emperador, en bibliografía no se encuentra tipo concreto.

11-GOBIERNO DE FRANCO. 10 Céntimos Madrid 1945

A.- ESPAÑA 1945. Jinete con lanza.

R.- [d) IEZ CE[ntimos ]. Escudo con águila imperial yugo y flechas.
Metal: Aluminio

1'7 gr.; $22 \mathrm{~mm}$.; $6 \mathrm{pc}$

Calicó et alii, 1994: P. 710, Tipo 23 n 140

Inv.:PS'13 11-1

Bibl.: Inédita

Yac: Yac: Refugio Plaza Séneca, Alicante

Observ: No

Francisco Lozano Olivares
C/ Luis Amigo,30
03009-Alicante
lozanoli.fran@gmail.com
Marcos Lumbreras Voigt
C/ Pardo Gimeno, 2, 3 C
03007-Alicante
marcusen72@gmail.com

ABREVIATURAS UTILIZADAS:

A.M.A.: Archivo Municipal de Alicante.

C.T.V. : Corpo Truppe Volontarie.

D.C.A: Defensa Contra Aeronaves.

D.E.C.A: Defensa Especial Contra Aeronaves.

M.Z.A: Madrid Zaragoza Alicante.

S.A.F.-15: Servicio de Aviación y Fabricación 15.

\section{BIBLIOGRAFÍA}

ALBERTI, S. y ALBERTI, E., 2004: Perill de bombardeig! Barcelona sota les bombes (1936-1939), Barcelona.

ÀLVAREZ, V. y MUÑOZ, V., 2011: «Informe sobre los refugios de la Guerra Civil en la Gran Vía de Valencia», Comissió de Llegat històric, Consell Valencià de Cultura, Valencia.

ARACIL, R. y VILLAROYA, J., 2010: El país Valencià sota les bombes (1936-1939), Valencia.

ARMENGOT, T. ET ALII, 2007: Castelló sota les bombes, Benicarló,

ARNABAT, R. e ÍNIIGUEZ, D., 2013: Atac i defensa de la rereguarda. Els bombardeigs franquistes a les comarques de Tarragona i Terres de l'Ebre 1936-1939, Valls.

ARNEDO, J.V., 2010: ¡Todos a los refugios! Refugios antiaéreos, bombardeos y defensa pasiva: Villena 19351939, Villena.

BEEVOR, A., 2007: La Guerra Civil española, Barcelona.

BENEITO LLORÍS, A., 2007: Alcoi, objetivo de guerra 1936-1939, Alcoy.

BESOLÍ, A., 2004: «Los refugios antiaéreos de Barcelona: pasado y presente de un patrimonio arcano», Ebre 38. Revista Internacional de la Guerra Civil (1936-1939), 2, 181-202.

BESOLÍ, A. y PEINADO, J., 2008: «El estudio y puesta en valor de los refugios antiaéreos de la guerra civil española: el caso del refugio-museo de Cartagena», Revista ArqueoMurcia, 3.

CALICÓ, F., CALICÓ, X. y TRIGO, J., 1994. Numismática Española. Catálogo de todas las monedas emitidas 
desde los reyes Católicos a Juan Carlos I. 1474-1994, Barcelona.

CALICÓ, X., 2008: Numismática Española. Catálogo de todas las monedas emitidas desde los reyes Católicos a Juan Carlos I. 1474-2001, Barcelona.

CAPDEPÓN, L., 2006: Alicante bombardeado (19361939). Análisis sesenta y cinco años después, Alicante.

CARDONA ESCANERO, G., 2009: «Els atacs aeris sobre Barcelona en el context de la guerra aèria, 1939-1945, 9-14», en R. Arnabat (ed.), Els refugis antiaeris de Barcelona. Criteris d'intervenció patrimonial, MUHBA. Documents, 7, Barcelona.

CASTELLANO, R., 2008: «La recuperación de vestigios arqueológicos de la Guerra Civil Española. Experiencia y método: el caso de Guadalajara», Complutum, 19, vol. 2, 33-46.

CASTELLANO, R. y SCHNELL QUIERTANT, P., 2013: «Arquitectura militar de la Guerra Civil en Madrid (Navalagamella y Quijorna)», Actas VII Jornadas de Patrimonio Arqueológico en la Comunidad de Madrid, 177185, Madrid.

CERDÁN TATO, E., 1986: «La masacre de los savoia», $C a$ nelobre, 7-8, 65-80.

CONTEL I RUIZ, J., 2008: Gràcia temps de bombes, temps de refugis. El subsol com a supervivencia, Barcelona.

CORPORALES LEAL, C., 2011: «Moneda y Guerra Civil Española», Revista Ab Initio, Núm. Extr. 1, 169-202.

CUHA G. y MICHAEL T., 2012: Standard Catalog of World Coins. 1801-1900, Ioia, Wisconsin.

DIEZ POMARES, G., 2011: Sant Vicent del Raspeig bombardeado (1938-1939). Atlas fotográfico, Alicante.

DOMENECH, X. y ZENOBI, L., 2009: Quan plovien bombes. Els bombardeigs i la ciutat de Barcelona durant la Guerra Civil, Barcelona.

EMILIANI, A., GHERGO, G. y VIGNA, A., 1974: La aviación legionaria. España 1936-1939, Madrid.

FERIA PÉREZ, R., 2002: 1937-2002. Principio y final de la peseta fiduciaria, Madrid.

FERRER, A., 2009: «Sobre el respeto y el rigor en la rehabilitación de los refugios», Revista ph. Instituto Andaluz del Patrimonio Histórico,70, 72-87.

GANDÍA ÁLVAREZ, E., 2013: «Proyecto de recuperación y puesta en valor del refugio de la Guerra Civil del antiguo mercado municipal de Cullera», en L. Alapont Martín i J. Martí Oltra (eds.), Actes III Jornades d'Arqueologia de València i Castelló, 217-226, Valencia.

GARCIA GANDIA J.R., 2010: Guerra y Moneda. La Fábrica Nacional de Moneda y Timbre en Aspe, Aspe.

GARCIA I MAS, A., y MARTÍNEZ I MEDINA, A., 2001: «Les defenses militars de la Guerra d'Espanya a Santa Pola», I Jornades del Patrimoni Cultural de Santa Pola, 31-38, Santa Pola.

GIL, E. y GALDÓN, E., 2007: «El patrimonio material», en A. Girona y J. M. Santacreu (dirs.), La Guerra civil en la Comunidad Valenciana, vol.17, Valencia.

GIL HERNÁNDEZ, E., 2013: «Entre búnkeres, trincheras y refugios antiaéreos: el patrimonio arqueológico de la Guerra Civil en Almansa», Jornadas de Estudios Locales, 7. Almansa siglo XX, 131-164, Almansa.
GONZÁLEZ RUIBAL, A. ET ALII, 2008: «Arqueología de la Guerra Civil Española», Complutum, 19, vol 2, 11-20.

GONZÁLEZ RUIBAL, A. ET ALII, 2010: «Guerra en la universidad: Arqueología del conflicto en la ciudad universitaria de Madrid», Ebre 38. Revista internacional de la Guerra Civil 1936-1939, 4, 123-143.

GONZÁLEZ RUIBAL, A. ET ALII, 2010: «Excavaciones arqueológicas en el frente de Guadalajara: Una posición franquista en Abánades (1937-1939)», Ebre 38. Revista internacional de la Guerra Civil 1936-1939, 5, 219-244.

GONZÁLEZ RUIBAL, A. ET ALII, 2011: «El último día de la Batalla del Ebro. Informe de las excavaciones arqueológicas en los restos de la Guerra Civil de Raïmats, La Fatarella (Tarragona)», CSIC.

GONZÁLEZ RUIBAL, A. ET ALII, 2012: «Arqueología de la batalla olvidada. Informe de las excavaciones en los restos de la Guerra Civil en Abádanes (Guadalajara). Campaña de 2012», CSIC.

INFIESTA PÉREZ, J. L., 1998: Bombardeos del litoral mediterráneo durante la Guerra civil, Vol. 1, Valladolid.

INFIESTA, J. L. y COLL, J., 2000: Bombardeos del litoral mediterráneo durante la Guerra civil, Vol. 2, Valladolid.

IZU, J., 2009: «De la protección civil a la gestión de emergencias. La evolución del marco normativo», Revista Aragonesa Admon Públicas, 35, 301-369.

LINDQVIST, S., 2002: Historia de los bombardeos, México.

LÓPEZ FRAILE, F.J. ET ALII, 2008: «La Batalla de Madrid (1936-39). Excavaciones en la defensa de la capital», Complutum, 19, 2, 47-62.

MAINAR, E., 2007: «Bajo las bombas, La Guerra civil en la Comunidad Valenciana», en A. Girona y J.M. Santacreu, (dirs.), La Guerra Civil en la Comunidad Valenciana, vol.14, Valencia.

MANRIQUE GARCÍA, J.M. y MOLINA FRANCO, L., 2006: Las armas de la Guerra Civil española. El primer estudio global y sistemático del armamento empleado por ambos contendientes, Madrid.

MARTÍNEZ LEAL, J., 1990: «República y Guerra Civil», en F. Moreno Sáez (dir.), Historia de la ciudad de Alicante, Edad contemporánea, Vol. IV, 269-336, Alicante.

MARTÍNEZ MIRA, L., 2005: Alicante 1936.1939. «Tiempos de guerra», Alicante.

MARTÍNEZ VELASCO, A., 2008: «Breve introducción a la cartuchería para arqueólogos», Sautuola, XIV, 383-398.

MARTORELL LINARES M. A., 2006: «Una guerra, dos pesetas», en E. Martínez Ruiz y P. Martín Aceña (coords.), La economía de la Guerra Civil, 329-356, Madrid.

MEZQUIDA FERNÁNDEZ, M., 2013: «Arqueología de la Guerra Civil. Una arqueología por asimilar», La Linde. Revista digital de arqueología profesional, 1, 42-50.

MEZQUIDA FERNÁNDEZ, M., 2014: «La pesada losa de hormigón sobre la memoria histórica en la ciudad de Valencia», La Linde. Revista digital de arqueología profesional, 3, 150-156.

MIRÓ I ALAIX, C. y RAMOS I RUIZ, J., 2011: «Els refugis antiaeris de Barcelona (1936-1939). Una nova visió des de l'arqueologia de la intervenció». Ex novo: revista d'història i humanitats, 2011, Núm. 7, 55-79. 
MORENO SAEZ, F. (Coord.), 2014: «1939. La guerra acaba en Alicante. Crónica de los últimos días de la contienda civil en la provincia, último objetivo militar de Franco», Suplemento especial en el 70 aniversario del final en Alicante de la Guerra Civil, Diario Información de Alicante.

MORENO, A. ET ALII, 2001-2002: «Espais de guerra a la Vall d'Albaida. Els refugis de la Guerra Civil», Alba, 16-17, 212-229.

MORENO, A. ET ALII, 2006: «Refugio antibombardeo del IV Cuerpo de Ejercito de la República Española en Alcohete (Guadalajara)», Castillos de España, 142-143, 87-91.

MORENO, A. y MUÑOZ, A., 2011: «Arqueologia de la memòria: els refugis antiaeris a la ciutat de València», Saguntum (P.L.A.V.), 43, 177-192.

MORTEN, H. y MOGENS, P., 2005: «Los negocios de la guerra. Armas nazis para la República española», Barcelona.

MUÑOZ COSME, A., 2009: «Arquitectura y Memoria. El Patrimonio Arquitectónico y la Ley de Memoria Histórica», Revista Patrimonio Cultural de España, Conservar o destruir: la ley de Memoria Histórica, 1, 83-102.

MUÑOZ, V. y HUGUET, J. 2004: «La conservación del patrimonio histórico militar de la Guerra Civil (19361939)», Comissió de Promoció Cultura, Consell Valencià de Cultura, Valencia.

MUÑOZ, V. y HUGUET, J. 2007: «Informe sobre refugios de la Guerra Civil, con mención particular a los de la ciudad de Valencia. Comisión de Legado Histórico y Artístico», Consell Valencià de Cultura, Valencia.

NASSAES, A., 1975: La aviación legionaria en la guerra española. Barcelona.

OREFFICE, S. y STELLAVATO, O., 2010: Inventario del fondo Operazione Militare Spagna (OMS), Ufficio Storico dell'areonautica Militare. Roma.

PASCUAL GARCÍA, S., 2010: «La Guerra Civil Espanyola i el seu patrimoni: Exemples de les intervencions arqueològiques a la demarcació de Barcelona i Lleida», Ebre 38. Revista internacional de la Guerra Civil 19361939, 4, 145-162.

PÉREZ-JUEZ, A. ET ALII, 2003: «El patrimonio arqueológico de la Guerra Civil: La necesidad de su conservación como testimonio de una época», Pátina. Época II, 12, 125-133.

PÉREZ-JUEZ, A. ET ALII, 2004: «El patrimonio arqueológico de la guerra civil. La protección de espacios asociados a la guerra civil española», Bolskan, 21, 171-180.

PERIZ SÁNCHEZ, D., 1999: La Fabrica Nacional de Armas de Toledo, Toledo.

PERMUY LÓPEZ, R.A. y O'DONELL, C., 2008: «As de picas». La escuadrilla de hidros de la Legión Condor en la Guerra Civil española (1936-1939), Valladolid.

PRAT, J. y PERICOT, J., 2012: Bombes sobre Girona. La defensa passiva a la Guerra Civil (1936-1939). Barricades, trinxeres i refugis antiaereis, Girona.

PRESTON, P., 2006: La Guerra Civil española, Badalona.

PUCHOL FRANCO, M., 2013: Torrevieja bombardeada, Torrevieja.
PUJADÓ, J., 2006: Contra l'oblit. Els refugis antiaeris poble a poble, Barcelona.

RAMOS PÉREZ, V., 1972: La Guerra Civil (1936-1939) en la provincia de Alicante, Alicante.

RODRÍGUEZ, J., 1962: «Refugios antiaéreos», Revista de Obras Públicas, 110, tomo I (2964), 245-258.

RODRIGUEZ, M.A. ET ALII, 2008: «La recuperación del legado arqueológico de la Guerra Civil Española. Construcciones y fortificaciones 70 años después», II Congreso Internacional sobre la República Española y la Guerra Civil, 70 años después, Madrid.

RUIZ NÚÑEZ, J., 2012: Sant Vicent del Raspeig en el contexto de las estructuras defensivas de l'Alacantí, Alicante.

SANTACANA, J., 2004: «Entre 1'oblit i la memoria: El patrimoni de la Guerra», Ebre 38. Revista Internacional de la Guerra Civil (1936-1939), 2, 169-180.

SANTACREU, J.M., 1986.: «El impacto de la guerra en la economía de la provincia de Alicante (1936-1939)», $\mathrm{Ca}$ nelobre, 7-8, 49-50.

SANTACREU, J. M., 1986: La crisis monetaria española de 1937. Moneda y municipios en la provincia de Alicante durante la Guerra Civil Española, Alicante.

SANTACREU, J.M., 1990: «La guerra y las principales actividades económicas de la ciudad», en F. Moreno Saez (dir.), Historia de la ciudad de Alicante, Edad contemporánea, Vol. IV, 339-352, Alicante.

SALAS LARRAZÁBAL, J., 2000: «Ofensiva en Levante», Enciclopedia de la aviación militar española, 12, 177192, Valladolid.

SALAS LARRAZÁBAL, J., 2008: La guerra de España desde el aire, Barcelona.

SCHNELL QUIERTANT, P., 2010: «Refugios antibombardeo de la Guerra Civil española en la Comunidad Valenciana», Castillos de España, 156 -157-158-159, 125-128.

SCHNELL QUIERTANT, P., 2010: «Refugios antibombardeo de la Guerra Civil Española en el Valle del Henares», Actas XII encuentro de Historiadores del valle del Henares, 351-364, Alcalá de Henares.

SCHNELL QUIERTANT, P., 2012: «La arqueología en el estudio de la fortificación de la Guerra Civil Española: Algunos ejemplos», IV Congreso de Castellología, 247 274, Madrid.

SCHNELL QUIERTANT, P., 2013: «Fortificaciones de la Guerra Civil Española en la Comunidad de Madrid». Castillos de España, 173-174, 1-12.

SECO SERRA, I., 2006: 151-167: «Monedas chinas en el Museo Cerralbo», Documenta \& Instrumenta, 4, 151-167.

SELVA INIESTA, A., 2000: Refugios antiaéreos en Albacete (Memoria para la paz), Cuadernos albacetenses 4, Albacete.

SOLÉ I SABATÉ, J.M. y VILLARROYA, J., 2003: España en llamas. La Guerra Civil desde el aire, Madrid.

SCHÜLER-SPRINGORUM, S., 2014: La guerra como aventura. La Legión Cóndor en la Guerra Civil española, Madrid. 
SECCIÓN TÉCNICA SERVICIO DE RECUPERACIÓN DE MATERIAL DE GUERRA. 1940: Clasificación de cartuchería de armas automáticas, fusiles, armas cortas y morteros. Región Centro, Madrid.

TENAS, A.M., 2014: «Patrimonio de la Guerra Civil: Un patrimonio de todos», La Linde, Revista digital de arqueología profesional, 3, 88-91.

TERUEL NAVARRETE, F., 2009: Estelas en el cielo. Alcublas, 1938, Alcublas.

UTRILLA NAVARRO, L., 2011: Historia de los aeropuertos de Alicante, Madrid.

VERA DELEITO, A. y VERA DE LEITO, J., 2000: Defensa Antiaérea Republicana (1936-1939). Artillería y Refugios (Algo de Valor), Valencia.

VICEDO JOVER, J., 1994: «El aeródromo de La Rabasa», Revista de Fiestas de San Vicente del Raspeig.
VIÑAS, A., 2006: La soledad de la República. El abandono de las democracias y el viraje hacia la Unión Soviética, Barcelona.

VIVES, O., 2013: «Experimentos de la Legión Cóndor a 1'Alt Maestrat, 1938», L'Avenç, 390, 37-43.

\section{REFERENCIAS ON LINE}

http://www.catalogodemonedas.es (Consulta: 1-9-2014). http://www.calgarycoin.com/reference/china/china8.htm (Consulta: 12-10-2014).

http://museumvictoria.com.au/collections/items/1375899/ coin-cash-emperor-kuang-hsu-qing-dynasty-china-1906 -1908. (Consulta: 12-10-2014).

Recepción: 14-05-2015

Aceptación: 27-08-2015 